Andrews University

Digital Commons @ Andrews University

1996

\title{
Improving the Assimilation of New Members in Small Adventist Churches in Central Pennsylvania
}

Robert C. Williams

Andrews University

Follow this and additional works at: https://digitalcommons.andrews.edu/dmin

Part of the Practical Theology Commons

\section{Recommended Citation}

Williams, Robert C., "Improving the Assimilation of New Members in Small Adventist Churches in Central Pennsylvania" (1996). Professional Dissertations DMin. 665.

https:dx.doi.org/10.32597/dmin/665

https://digitalcommons.andrews.edu/dmin/665

This Project Report is brought to you for free and open access by the Graduate Research at Digital Commons @ Andrews University. It has been accepted for inclusion in Professional Dissertations DMin by an authorized administrator of Digital Commons @ Andrews University. For more information, please contact repository@andrews.edu. 


\begin{abstract}
IMPROVING THE ASSIMILATION OF NEW MEMBERS

IN SMALL ADVENTIST CHURCHES

IN CENTRAL PENNSYLVANIA
\end{abstract}

by

Robert C. Williams

Adviser: Douglas R. Kilcher 


\section{ABSTRACT OF GRADUATE STUDENT RESEARCH \\ Dissertation \\ Andrews University \\ Seventh-day Adventist Theological Seminary}

\section{TITLE: IMPROVING THE ASSIMILATION OF NEW MEMBERS IN SMALL ADVENTIST CHURCHES IN CENTRAL PENNSYLVANIA}

Name of researcher: Robert C. Williams

Name and degree of faculty adviser: Douglas R. Kilcher, D.Min.

Date completed: April 1996

\section{Problem}

The failure of many of our small Seventh-day Adventist congregations to fully welcome new members into their midst has been of pastoral concern for many years. This project is an attempt to build awareness among established church members of the need to assimilate and sacrifice for new members.

\section{Method}

The first part of the project involved research into the assimilation of new members in ten small Adventist congregations in central Pennsylvania. New members who had joined the church during a six-year interval were studied to see if they had maintained active membership status during that time. Interviews were also conducted with three pastors, four active SDA members, and four inactive members to explore their views about assimilating new members. A seminar was conducted in three churches to alert their membership to the needs of 
new members, and their own roles in assimilating them into their congregations. An attempt was made to ascertain the effectiveness of that approach in changing attitudes with respect to new members by comparing results from a pre-seminar questionnaire (given to the entire church about one month prior to the seminar) and a very similar questionnaire administered at the close of the seminar.

\section{Results}

The findings of the questionnaires regarding the effectiveness of the seminar in changing attitudes with respect to new members were inconclusive. The hope that church members would attend the seminar in large numbers was usually not realized. Therefore, the pool of those taking the follow-up questionnaire was more selective than the pool of those taking the pre-seminar questionnaire, making any conclusions reached by direct comparisons of the answers unreliable. However, subjective analysis of the behaviors of the churches involved and their assimilation percentages was revealing.

\section{Conclusions}

There is a definite comparison between the personal effort the church membership is willing to extend in support of new member assimilation and the likelihood that new members will become active in its fellowship. Churches with higher assimilation rates showed greater interest in the seminar than those with lower assimilation rates. An exception was noted in the smallest church surveyed. It had a large seminar attendance but a very poor record of assimilation. This suggests that factors other than the church's willingness to personally welcome newcomers might be involved. Real change in attitude among the membership in small church settings is not likely to result from one or two seminars alone, but will require ongoing vision-casting by the leadership through sermons, lessons, and personal example. 


\author{
Andrews University \\ Seventh-day Adventist Theological Seminary
}

\title{
IMPROVING THE ASSIMILATION OF NEW MEMBERS IN SMALL ADVENTIST CHURCHES IN CENTRAL PENNSYLVANIA
}

A Dissertation

\author{
Presented in Partial Fulfillment \\ of the Requirements for the Degree
}

Doctor of Ministry

by

Robert C. Williams

April 1996 


\section{IMPROVING THE ASSIMILATION OF NEW MEMBERS \\ IN SMALL ADVENTIST CHURCHES \\ IN CENTRAL PENNSYLVANIA}

A dissertation

presented in partial fulfillment

of the requirements for the degree

Doctor of Ministry

by

Robert C. Williams

APPROVAL BY THE COMMITTEE:

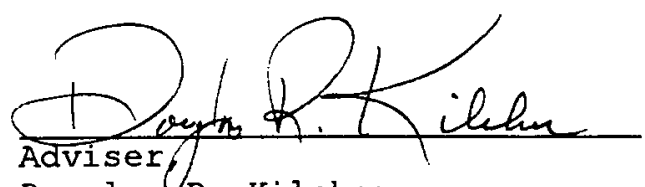

Douglas R. Kilcher
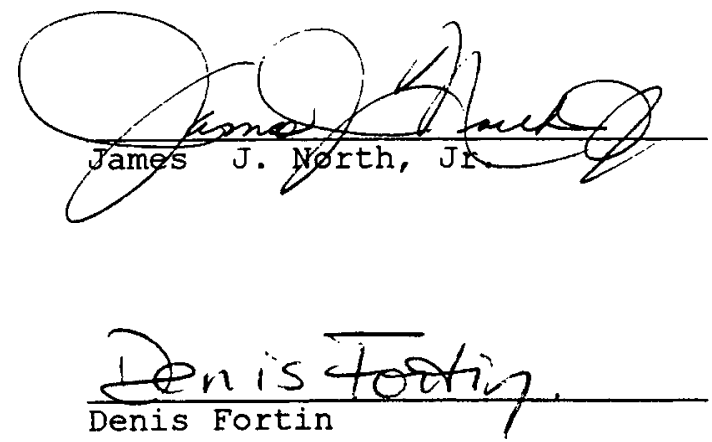

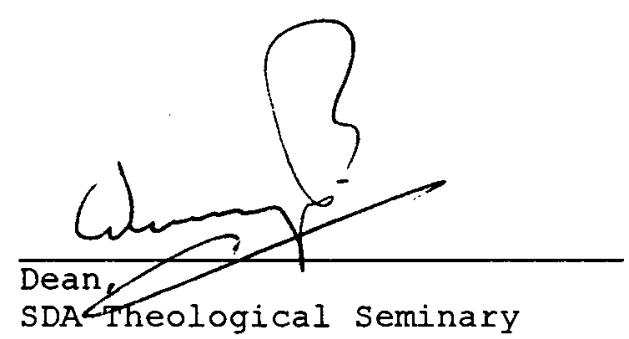

$\frac{\text { Decomber } 12,1996}{\text { Date approved }}$ 
TABLE OF CONTENTS

LIST OF ILLUSTRATIONS . . . . . . . . . . . . . . . . . . . . vi vi

LIST OF TABLES . . . . . . . . . . . . . . . . . . . . . . . . . vi vi

ACKNOWLEDGMENTS . . . . . . . . . . . . . . . . . . . . vii

Chapter

1. INTRODUCTION . . . . . . . . . . . . . . . . . . . . 1

Purpose of the Project . . . . . . . . . . . . . . . . . 1

Justification . . . . . . . . . . . . . . . . . . . . . 2

The Prevalence of Small Churches . . . . . . . . . 2

The Effectiveness of Small Churches

Relative to Growth

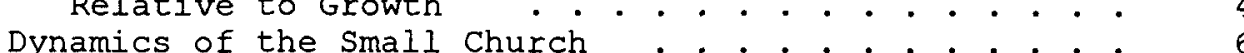

Screening in Small Congregations . . . . . . . 6

The Family Church (1-50 Members) . . . . . . . . 6

The Pastoral Church (51-100 Members). . . . . . . 8

Assimilation, the Moral Choice . . . . . . . . 8

Expectations for the Project . . . . . . . . . . . 9

Definition of Terms .. . . . . . . . . . . . . . . 10

Limitation of the Project. . . . . . . . . . . . . . . . 11

Method . . . . . . . . . . . . . . . . . 11

2. ASSIMILATION IN SMALL CHURCHES . . . . . . . . . . . 13

Review of Statistical Material

Concerning Evangelism and

Assimilation in Central Pennsylvania . . . . . . . . 13

Description of the Research Project . . . . . . . . 13

The Findings of the Ten-Church Survey . . . . . . . . 14

Summary and Conclusions . . . . . . . . . . . . . 16

Findings from the Interviews . . . . . . . . . . . . . 18

Pastoral Interviews . . . . . . . . . . . . . . . 18

Member Interviews . . . . . . . . . . . . . . . 23

Summary of the Interviews . . . . . . . . . . . 29

Literature Review on Assimilation in Small Churches . . . 30

The Shrinking Church in North America . . . . . . . 30

The Unique Characteristics of Small Churches . . . . . 31

Basic Small Church Structures........... 31

Basic Small Church Culture . . . . . . . . . 33

Member Involvement . . . . . . . . . . . . . 39

The Choice to Remain Small . . . . . . . . . . . . . . 40

Reasons for Choice .. . . . . . . . . . . . 41

Barriers to Fellowship . . . . . . . . . . . . . 42

The Possible Results of Choosing Not to Grow. . . . 47

Growth and the Small Church . . . . . . . . . . . 48

Norms .. . . . . . . . . . . . . . . . . 48

Assimilation . . . . . . . . . . . . . . . . . . 49

Types of Growth . . . . .. . . . . . . . . 51 
Assimilation in the Small Church . . . . . . . . . 52

The Importance of Friendships . . . . . . . . . 53

The Assimilation Process . . . . . . . . . . . 55

Barriers to Assimilation . . . . . . . . . . 60

New Member Development . . . . . . . . . . . 62

Assimilation from the New Member's Viewpoint . . . . 65

Synthesis . . . . . . . . . . . . . . . . . . 66

A Theology of Assimilation . . . . . . . . . . . . 68

Assimilation and the Church . . . . . . . . . . . 68

God's Attitude Toward Us . . . . . . . . . . . 69

Four Biblical Models for Assimilation . . . . . . 70

Vines, Branches, and Grafting In . . . . . . . 70

The Body of Christ and Its Members . . . . . . . . 71

The Family of God and Adoption . . . . . . . . . 74

The Kingdom of God and Naturalization . . . . . . . 77

The Whole Duty of the Church . . . . . . . . . . 79

Reflection....................... . . . . 80

Current Strategies in Assimilation . . . . . . . . . 80

3. A DESIGN FOR INCREASING THE AWARENESS OF NEED FOR

A Theoretical Model for Building Awareness of

The Church's Need to Assimilate New People

The Construction of a Technique for Bringing

This Awareness to the Local Congregation and

Leading Them to a New Vision of Their Role

In Receiving New Members into Fellowship... . . . .

4. IMPLEMENTING THE PROCESS . . . . . . . . . . . . . . . . 100

Choosing the Churches . . . . . . . . . . . . . . . 100

The Seminar and Questionnaire on Assimilation . . . . 101

Results of Implementation of the Seminar . . . . . . . . 104

The Initial Questionnaire and Its Results . . . . . . 104

Membership Demographics . . . . . . . . . . . 104

Member's Experience with the Local Church . . . . 106

Member's View of the Church's Mission . . . . . . 106

Membership's Commitment to the Church's Mission . . 108

Membership's Attitudes toward Assimilation

Of New Members . . . . . . . . . . . . 109

Membership's Behavior toward New Members . . . . 110

Membership's Evaluation of the Church's

Performance toward New Members . . . . . . . 111

The Follow Up Questionnaire and Its Comparisons . . . 112

Membership Demographics . . . . . . . . . . 113

Members' Experience with the Local Church . . . 114

Members' View of the Church's Mission . . . . . . 115

Membership's Commitment to the Church's Mission . . 115

Membership's Attitudes toward Assimilation

Of New Members . . . . . . . . . . . . 117

Membership's Behavior toward New Members . . . . 117

Membership's Evaluation and Commitment to Improve

the Church's Performance toward New Members . . 118

Observations on Church Behavior Beyond the

Questionnaires and Their Possible Meanings . . . . 121

Answers to Questions versus Seminar Attendance . . 121

Answers to Concept Questions versus Behavioral

Questions . . . . . . . . . . . . . . 122

Program Evaluation . . . . . . . . . . . . . . . 123 
Appendix

A. THE TEN-CHURCH SURVEY AND ITS RESULTS. . . . . . . . . . . . 132

B. QUESTIONNAIRES AND INTERVIEWS AND THEIR RESULTS. . . . . . . 137

C. THE SEMINAR . . . . . . . . . . . . . . . . . . . . . . 168

D. SUGGESTIONS CONCERNING THE SPRIRITUAL GUARDIAN PROGRAM . . . 192

E. SUPLEMENTARY ARTICLES AND CHARTS . . . . . . . . . . . . . . 195

BIBLIOGRAPHY . . . . . . . . . . . . . . . . . . 201

VITA............................ 206 
1. Schaller's Concept Showing Levels of Church Fellowship . . .

2. Scale of Judgments upon a Continuum Involving

Assimilation Range and the Contrast Ranges

Relative to a Person's Personal Reference Scale.....

1. SDA Churches by Membership Size . . . . . . . . . . . 3

2. Distribution of Membership by Church Size . . . . . . . 3

3. Growth in Seventh-day Adventist Churches by Church Size • . 4

4. SDA Average Growth Rates by Church Size . . . . . . . . . . 5

5. SDA Kingdom Growth by Church Size . . . . . . . . . . . . 5

6. The Summary of Results Concerning Assimilation by Church . . 15

7. Percentage Retained Compared to Evangelistic Method . . . . 15

8. The Importance of Friends in the Church . . . . . . . . . . 54

9. The Distribution of Age in the Church Congregations Surveyed by Percentage of those Tested... . . . . . 105

10. The Progression of Member Responses Moving From Concept
Statements to Behavior . . . . . . . . . . . . . 108

11. Answers to Statements Showing Personal Commitment . . . . . . 116

12. Members' Commitment to Assimilate New Members . . . . . . 118 


\section{ACKNOWLEDGMENTS}

I feel there are many who have had a hand in the completion of this project whom I would like to mention here. First among them is my wife, Amy, and my children, who have patiently endured my absences and encouraged me in my research. Then there were the clerks and pastors of the churches I studied, all of whom were extremely cooperative in gathering information and passing out questionnaires to their constituents in preparation for the seminars held there. Without their faithfulness, I would never have been able to proceed in this undertaking.

I would also like to thank my churches. In addition to being a guinea pig to some of my experiments, they have patiently waited through several years for their pastor to return from his academic exile. They have never complained about the time I was not able to spend with them as a result of this project, but have been encouraging and helpful in every way, even breaking into my reveries and forcing me to come out to enjoy a few moments with them in the spiritually cleansed air.

The Librarian at the Lutheran Theological Seminary at Gettysburg, Pennsylvania, has also been most helpful. Her efforts made it possible for me to borrow books and order materials through her institution which I would otherwise have had to travel long distances to acquire.

And finally, my gratitude goes out to the administrators and teachers involved in the Doctor of Ministry program at The Seventh-day Adventist Theological Seminary of Andrews University. Without their vision and their willingness to travel, many of us, in the fields of the Lord, would never be able to study so deeply into our field of ministry. vii 
Special thanks go to Dr. Kilcher, my committee chairman and adviser; Dr. North, for his advice and counsel and for consenting to be on my committee; and Bonnie Proctor, who has spent hours proofreading my material. Also, I would like to thank Drs. Holmes and Samaan for the patience they have shown me in granting my extensions, that I might be enabled to continue working on this project and bring it to completion despite the pressures facing me in my pastorate. 
The inspired writings of Ellen $G$. White give this counsel to the church regarding the care needed when dealing with new believers:

Those who have newly come to the faith should be patiently and tenderly dealt with, and it is the duty of the older members of the church to devise ways and means to provide help and sympathy and instruction for those who have conscientiously withdrawn from other churches for the truth's sake, and thus cut themselves off from the pastoral labor to which they have been accustomed. The church has a special responsibility laid upon her to attend to these souls who have followed the first rays of light they have received; and if the members of the church neglect this duty, they will be unfaithful to the trust that God has given them. ${ }^{1}$

\section{Purpose of the Project}

Recent survey results indicate that "we must take urgent action" to preserve the Seventh-day Adventist $(\mathrm{SDA})^{2}$ membership's willingness to believe and act according to "the commands of scripture, and the counsels and urging of the spirit of Prophecy." ${ }^{3}$ Some of those commands, as seen above, relate to the "care and feeding" of new members.

Church researchers point out that "closing the back door is just as much a part of real church growth as is opening the front door."

${ }^{1}$ Ellen G. White, "Our Youth and Children Demand Our Care," The Advent Review and Sabbath Herald, 28 April 1896, 257.

\footnotetext{
2 From this point on the term "Seventh-day Adventist" is abbreviated as "SDA."

3 "New Directions," Adventist Review, 30 December 1993, 16.

${ }^{4}$ Roger L. Dudley and Des Cummings, Jr., "A Study of Factors Relating to Church Growth in the North American Division of Seventh-day Adventists"

(Berrien Springs, MI: Andrews University Institute of Church Ministry, 1981), 6.
} 
Those churches that discover how to become the "caring church," and not just talk about it, will discover how to perform this feat.

The purpose of this project is to develop an approach that will increase the potential of our small (under 100 members) and very small churches (under 50 members) to assimilate and nurture new members. If this is done properly, it is hoped churches will not see the attrition that has stifled their growth in the past.

\section{Justification}

The Prevalence of Small Churches

"The normal size for a Protestant congregation on the North American Continent is one that has fewer than forty people at worship." An estimated 50 to 70 percent of the churches of most denominations are small membership churches. ${ }^{2}$ Yet the majority of the North American church members (508 and above), ${ }^{3}$ and the leaders of those church organizations, ${ }^{4}$ belong to "statistically large churches."

Seventh-day Adventist church figures follow those of other denominations. Ministry magazine published figures showing that 899 of the 4,226 churches in North America had memberships of 200 or more; 920 had between 100 and 199 members; the remaining 2407 churches had less than 100 members. ${ }^{5}$

${ }^{1}$ Lyle E. Schaller, The Small Church Is Different (Nashville, TN: Abingdon, 1982), 9.

${ }^{2}$ V. Gilbert Beers, "Big Footprints from Small Churches," Christianity Today, 8 August 1986, 10.

${ }^{3}$ David R. Ray, Small Churches Are the Right Size (New York: Pilgrim Press, 1982), 31.

${ }^{4}$ Schaller, The Small Church Is Different, 11.

${ }^{5}$ Ray, 31.

${ }^{6}$ B. Russell Holt, "The Small Church Advantage," Ministry, March 1987, 18. (These figures excluded companies and the conference churches.) 
Another study shows that the largest number of SDA churches in North America have under 100 members (59.88). ${ }^{1}$ This was a sampling of 249 SDA churches in North America. (See table 1.)

Table 1.--SDA churches by membership size

\begin{tabular}{|c|c|c|c|}
\hline Size & No. of Churches & $\begin{array}{c}\text { Percentage of } \\
\text { Total }\end{array}$ & $\begin{array}{c}\text { Curmulative } \\
\text { Percentage }\end{array}$ \\
\hline $1-50$ & 77 & 30.9 & 30.9 \\
\hline $51-100$ & 72 & 28.9 & 59.8 \\
\hline $101-150$ & 36 & 14.4 & 74.3 \\
\hline
\end{tabular}

Source: Roger L. Dudley and Des Cummings, Jr., "A Study of Factors Relating to Church Growth in the North American Division of Seventh-day Adventists" (Berrien Springs, MI: Andrews University, Institute of Church Ministry, April 1981), 27.

So while most SDAs are in larger churches, and only a fifth have membership in churches with less than 100 members (see table 2), it appears that the largest geographical area, and therefore the largest potential mission area in North America, is serviced by small and very small congregations.

Table 2.--Distribution of membership by church size

\begin{tabular}{|c|c|}
\hline Church Size by Membership & Percentage of Total NAD Membership \\
\hline $600+$ & 24 \\
\hline $300-599$ & 24 \\
\hline $100-299$ & 33 \\
\hline $0-99$ & 19 \\
\hline
\end{tabular}

Source: "Membership Size Distribution: Percent of NAD Members," The SDA Church Directory (Hagerstown, MD: Review and Herald, Research and Development, 1987). (Chart in RCW personal library, reproduced in appendix)

\footnotetext{
${ }^{1}$ Dudley and Cummings, 27.
} 
The Effectiveness of Small Churches Relative to Growth

Some small churches can be effectively evangelistic in their

communities. Church size seems to influence their growth potential.

The 1981 study on SDA church growth shows that the smallest

congregations (under 50 members) find growth very hard, while the

51-100-member churches are growing more easily. ${ }^{1}$ (See table 3.)

Table 3.--Growth in Seventh-day Adventist churches by church size

\begin{tabular}{|c|c|c|}
\hline $\begin{array}{c}\text { Size of Church } \\
\text { in Membership }\end{array}$ & $\begin{array}{c}\text { Percentage of Churches } \\
\text { Stagnant or Declining }\end{array}$ & $\begin{array}{c}\text { Percentage of Churches } \\
\text { with Some Growth }\end{array}$ \\
\hline $1-50$ & 63.2 & 36.8 \\
\hline $51-100$ & 36.1 & 63.8 \\
\hline $101-150$ & 27.8 & 72.2 \\
\hline $151-200$ & 37.5 & 62.5 \\
\hline $201-300$ & 41.2 & 58.8 \\
\hline $301-400$ & 30.0 & 70.0 \\
\hline $401-500$ & 33.3 & 66.7 \\
\hline $501+$ & 40.0 & 60.0 \\
\hline
\end{tabular}

Source: Roger L. Dudley and Des Cummings, Jr., "A Study of Factors Relating to Church Growth in the North American Division of Seventh-day Adventists" (Berrien Springs, MI: Andrews University, Institute of Church Ministry, April 1981), 30.

When these findings are placed into actual average growth figures for churches it was found that churches in the 50 to 150 membership ranges grow the fastest, and those below 50 members show the least growth of any church. ${ }^{2}$ (See table 4.) When figures are adjusted to consider kingdom growth, ${ }^{3}$ a similar pattern emerges. ${ }^{4}$ (See table 5.)

${ }^{1}$ Dudley and Cumings, 30 .

2 Ibid, 28.

3 "Kingdom growth" refers to that measure of church growth that is not attributable to members transferring in from other denominational churches or to the inevitable acceptance into membership of children born in the congregation. True kingdom growth occurs only when those outside the church "kingdom" come in.

${ }^{4}$ Kerry H. Hortop, "The Church as Family: A Study of Viability in the Smaller Local Seventh-day Adventist Church" (D.Min. project report, Andrews Univerity, Berrien Springs, MI, 1980), 181. 
Table 4.--SDA average growth rates by church size

\begin{tabular}{|c|c|c|}
\hline Size of Congregation & Number of Churches & $\begin{array}{c}\text { Average Actual Growth by } \\
\text { Percentages }\end{array}$ \\
\hline $1-50$ & 76 & 2.1 \\
\hline $51-100$ & 72 & 9.7 \\
\hline $101-150$ & 36 & 9.8 \\
\hline $151-200$ & 16 & 3.0 \\
\hline $201-300$ & 17 & 4.2 \\
\hline $301-400$ & 10 & 4.4 \\
\hline $401-500$ & 6 & 8.1 \\
\hline $501+$ & 15 & 5.0 \\
\hline
\end{tabular}

Source: Roger L. Dudley and Des Cummings, Jr., "A Study of Factors Relating to Church Growth in the North American Division of Seventh-day Adventists" (Berrien Springs, MI: Andrews University, Institute of Church Ministry, April 1981), 28.

Table 5.--SDA kingdom growth by church size

\begin{tabular}{|c|c|c|c|}
\hline Size of Church & $\begin{array}{c}\text { Avg. Kingdom Growth } \\
8\end{array}$ & $\begin{array}{c}\text { 8 Churches with } \\
\text { No Kingdom Growth }\end{array}$ & $\begin{array}{c}\text { 8 Churches with } \\
\text { Kingdom Growth }\end{array}$ \\
\hline $1-50$ & 4.4 & 56.1 & 43.8 \\
\hline $51-100$ & 6.6 & 35.0 & 65.0 \\
\hline $101-150$ & 6.2 & 17.4 & 82.6 \\
\hline $151-200$ & 5.5 & 14.3 & 85.7 \\
\hline $201-300$ & 3.7 & 17.6 & 82.4 \\
\hline $301-400$ & 2.8 & 20.0 & 80.0 \\
\hline $401-500$ & 3.8 & 33.3 & 66.7 \\
\hline $501+$ & 5.4 & 9.1 & 90.0 \\
\hline
\end{tabular}

Source: Kerry H. Hortop, "The Church as Family: A study of Viability in the Smaller Local Seventh-day Adventist Church" (D.Min. project report, Andrews University, Berrien Springs, MI, 1980), 100.

So the range of this study into assimilation in the world of the small church reveals two categories of congregations--the very small church (1 to 50 members) and the small church (51 to 100 members). Kingdom growth is occurring in each category, yet many churches do not

${ }^{1}$ The discrepancy between the number of churches represented in the 1-50 membership category of this table with the same category of table 1 is due to the dropping of one church from consideration by the researchers. It had experienced an artificial influx of 25 transfer members from a sister church in an effort to save it during the 6 month term of the study. The resulting growth lead to a distorting of the statistical material except where kingdom growth is concerned. 
grow. The reason for this can be found in the dynamics of the small church, or primary group. ${ }^{1}$

\section{Dynamics of the Small Church}

$\underline{\text { Screening }}^{2}$ in Small Congregations

I have personally struggled with my churches to help them to become more inviting to "outsiders." There is often a resistance among the membership to doing the things necessary to fully assimilate new members. This type of behavior has been dubbed "screening." ${ }^{3}$

Everyone is not welcome in the small church, regardless of the cordiality shown to visitors at the door. ${ }^{4}$ The clannish qualities of the small church community demand that new faces be assessed for the effect their presence will have on the existing members of the church and the church community as a whole before they will be let "in." Lyle Schaller observes: "In many congregations it is easier to become a member than it is to be accepted and made to feel so." 6

The Family Church (1-50 Members)

In researching churches, Arlin J. Rothauge determined that the structure a church takes is determined, in a large part, by its membership size. He therefore divided churches into four major

${ }^{1}$ Small churches function after the characteristics of primary or cell groups. Carl S. Dudley, Unique Dynamics of the Small Church (Washington, DC: Alban Institute, 1977), 5-6.

2 See the definition of "screening" on page 11 .

${ }^{3}$ John S. Savage, Kenneth J. Mitchell, and Joyce C. Nelson, Lab I Leader's Guide (Pittsford, NY: LEAD Consultants, 1981), 6.

${ }^{4}$ Roy M. Oswald, Making Your Church More Inviting (New York: Alban Institute, 1992), 49.

${ }^{5}$ Roy M. Oswald and Speed B. Leas, The Inviting Church: A Study of New Member Assimilation (New York: Alban Institute, 1987), 32. 1978), 73.

${ }^{6}$ Lyle E. Schaller, Assimilating New Members (Nashville, TN: Abingdon, 
categories and studied their structural dynamics with respect to this variable. ${ }^{1}$ Rothauge's categories are as follows:

1. Family Church, 0 - 50 members

2. Pastoral Church, 50 - 150 members

3. Program Church, 150 - 350 members

4. Corporate Church, 350 - 500 members. $^{2}$

For the purposes of this project report, only the family and pastoral churches are discussed--with a limit of 100 members for the latter. Both church groups (family and pastoral) are similar in this respect in that they are still small enough for everybody to know everybody else and present a united front to the world around them. It is partially the need to protect this sense of unity that motivates the screening behavior previously mentioned.

Churches of this size function primarily as a family organization. ${ }^{3}$ The family is in the form of a single social cell, held together by deep ties of history and blood relationships. "This type of church can produce a nurturing environment for those native to its care. Since the sense of unity enjoyed by the small church begins to dissolve with increasing size, the extra effort required of the congregation to maintain this closeness breeds a negative motivation toward growth. 5 Church researcher, Carl Dudley, refers to this church as "a special kind of primary group," a single cell. Single-cell primary groups are defined by this characteristic: "every member expects to

${ }^{1}$ Arlin J. Rothauge, Sizing Up a Congregation for New Member Ministry (New York: Seabury Professional Services, n.d.), 5.

2 Ibid.

3 Ibid., 7.

${ }^{4}$ L. Ray Sells and Ronald K. Crandall, The Small Membership Church--Growing, Caring, Serving: A Manual for Evangelism Ministries (Nashville: Discipleship Resources, 1982), 7.

schaller, Assimilating New Members, 126. 
know, or to know about, every other member."' He also characterizes these groups as "culture-carrying congregations who bring their identity from the past." The group has become satisfied with its experience, feeling no need to grow, because its single cell has probably already reached the limits to which it can still preserve its "face to face knowing and caring" experience with each member. ${ }^{2}$ Therefore the small church fights to stay small although it may profess another desire. ${ }^{3}$

The Pastoral Church (51-100 members)

As the size of a congregation grows beyond the fifty-member mark, the single cell structure breaks down. The single cell becomes "2 to 3 cells of quite intense relation." 4 The parental figures of the matriarch and patriarch can no longer hold everything together. Control of the church is therefore delegated to the pastor. ${ }^{5}$

In spite of the changes in structure, however, the pastoral church has many of the same difficulties with assimilation as the family church--plus one. Since there is no gatekeeper to bring interested parties into the church and introduce them around, ${ }^{6}$ the pastor is expected to handle all contact with newcomers. ${ }^{7}$ As a result, the members become indifferent and casual to the needs of newcomers. ${ }^{8}$

\section{Assimilation, the Moral Choice}

Lyle Schaller writes: "It is un-Christian for a congregation to seek new members unless it is also willing and able to accept them into

${ }^{1}$ Dudley, Unique Dynamics, 6.

${ }^{2}$ Ibid., 6-7.

${ }^{3}$ Lyle E. Schaller, Growing Plans (Nashville, TN: Abingdon, 1983), 20-21.

${ }^{4}$ Rothauge, 15.

${ }^{5}$ Ibid.

${ }^{6}$ Rothauge, 17.

'Oswald and Leas, 33; Rothauge, 17.

${ }^{8}$ Ibid. 
that called-out community."1 Many Seventh-day Adventist churches and their members are faced with a dilemma as a result of this truth. When asked if they feel they should bring in new members, almost every person in the church will say "Yes."2 Yet, when it comes to paying the cost for growth in congregational change and strains on the existing fellowship, members draw back. Concerning this Loren B. Mead writes in his book More than Numbers:

Congregations . . have paid little attention to socialization. We are told that half the new members who join a congregation disappear within two years. From a strict system's point of view, that is terribly costly. . . But beyond a systems point of view, the congregation has also violated its own beliefs and values. They have failed to receive and give hospitality to one of God's children who was seeking to make a home in the community. ${ }^{3}$

\section{Expectations for the Project}

Ultimately I hope to learn how to lead small churches into greater growth. Retention of new members is obviously as important to church growth as evangelism.

A community is not caring that cares only for itself. This project will benefit the local church by helping it to see any needs it may have toward strengthening its caring community and by extending it. The conference in which this project is completed may gain a training tool with which to prepare its churches for more effective growth.

There are other benefits. I hope to facilitate the eventual development of a method by which pastors may prepare their churches to receive new members before holding evangelistic outreaches. Increased understanding of the dynamics of small churches will help me facilitate

\footnotetext{
${ }^{1}$ Schaller, Assimilating New Members, 128.
}

${ }^{2}$ Surveys given in three smaller-sized congregations in Central Pennsylvania agreed that when asked if their church should grow and receive new members, the answer was nearly a unanimous "yes." The surveys are covered later in this paper, and their results are in the appendix $B$.

${ }^{3}$ Loren B. Mead, More than Numbers: The Way Churches Grow (New York: Alban Institute, 1993), 77, 78 . 
this. Healthy, growing churches incorporate people rapidly into the Iife of the church, ${ }^{1}$ and everyone shares the workload. ${ }^{2}$

\section{Definition of Terms}

Small Church: The term "small church" designates the combination of both the family and the pastoral church categories so long as membership is at or below 100 members.

Active Membership: This paper uses a functional definition of active membership. An active member is one who attends church at least every other Sabbath and is involved in the church in some way other than worship attendance.

Growth Capacity: "The growth capacity of any church can be measured by simple compilation of the number of potential small groups through which the new members can be assimilated." ${ }^{3}$ The church needs places for its new members. This capacity is found in its fellowship opportunities.

Assimilation: Assimilation is the processing of new members to "incorporate them into the life, the emotion, the ministry of the congregation." ${ }^{4}$ They need to become an integral part of the church. ${ }^{5}$

This process is also called "Socialization." Socialization is the process by which a stranger is brought into a group. . . . It is one of the critical processes in any social system. Where it is done well, the new member rapidly becomes an effective contributing member. Where it is not done well, the new member is frustrated, unproductive, and frequently disappears from the group before long. ${ }^{6}$

${ }^{1}$ Roger Lewis Dudley, Des Cummings, and Tim Garrison, "A Study of Factors Relating to Church Growth in the Ohio Conference of Seventh-day Adventists" (Berrien Springs, MI: Andrews University Institute of Church Ministry, 1983), 45.

${ }^{2}$ Faith, Action, Advance: Dynamics of Church Growth (Washington, DC: North American Division of the General Conference of Seventh-day Adventists, 1982), 4 .

${ }^{3}$ Dudley, Unique Dynamics, 14.

"John S. Savage, "The Teflon Church," Leadership 11 (Fall 1990): 31.

${ }^{5}$ Ibid.

${ }^{5}$ Mead, 78. 
Screening: Dr. John Savage tells those taking his "Lab I" seminars that "the local congregation knows who it wants and who it doesn't want in its membership." Therefore, they develop unconscious but effective behaviors to "screen" out the unwanted and let in the desirable. Most congregations are not aware of this subtle behavior. ${ }^{1}$

Norms: Screening behavior is most likely to be observed when a newcomer transgresses the "norms" by which a congregation operates. "Norms are those unwritten psychological rules that govern behavior in any human community." ${ }^{2}$ They are not published, but every member learns to follow them without conscious thought: i.e., "only vegetarian dishes are served at SDA fellowship meals."

Kingdom Growth: "Kingdom growth" considers only those new additions to the fellowship that come from sources outside the church. Biological growth (from children of members) and transfer growth (from people who transfer from another SDA fellowship) are not counted.

\section{Limitations of the Project}

This project covers only assimilation of new members into the small and very small church; it does not deal with transfer members entering from other Adventist churches who may already be familiar with our norms and mission. It is limited in place to the study of churches in central Pennsylvania.

\section{Method}

This project began with a literature review of small church dynamics and new member assimilation. Then the growth statistics of ten small churches in central Pennsylvania were studied for six years to determine whether new members have remained active or not. An attempt was made to determine if there is a difference between those brought in

\footnotetext{
${ }^{1}$ Savage, Mitchell, and Nelson, Lab I Leader's Guide, Session I, 6.

${ }^{2}$ Oswald, 43.
} 
by public evangelism and those who entered the church another way. In-depth interviews with three pastors, four assimilated members, and four non-attending members were conducted to determine their experience in the church and how it relates to their present status. Seminars were presented in three cooperating small churches. A questionnaire was given to church members three to four weeks prior to each seminar to ascertain their present awareness of the problems new people may face in entering their fellowship. A follow-up questionnaire was given after the seminar. These questionnaires were an attempt to measure the effectiveness of the seminar in building the membership's awareness with respect to new members and their needs by comparing the results from the pre-seminar questionnaire and the post-seminar questionnaire for any changes in attitude it may have stimulated. 
CHAPTER 2

ASSIMILATION IN SMALL CHURCHES

\section{Review of Statistical Material Concerning Evangelism and Assimilation in Central Pennsylvania \\ Description of the Research Project}

As a part of this project, ten small churches were surveyed in Central Pennsylvania to determine how well they had incorporated new members into their fellowships. Survey forms were sent to the clerks of each of these churches asking for their help in tracking the course of new members among them over the past six years (1988 to 1993). ${ }^{1}$ The survey sheet asked for the person's name, the date he or she joined the church (baptism or profession of faith only), and current status with the church (Active, ${ }^{2}$ Inactive, Dropped, Transferred, or Dead). Those who transferred out were assumed active.

The survey also asked the clerks to report, where possible, how the persons in the survey came into the church. The purpose of this was to try to gain some idea as to the effectiveness of our various methods of promoting church growth with respect to the individual member's assimilation into the congregation. The areas surveyed were: "personal ministry" (friendship, lay Bible studies, pastoral Bible studies), "biological" (children of church members who join), and "evangelistic

${ }^{1}$ Although the project proposal stated that this study would be done only over a three-year period, I found that many small churches did not have new members join them during this period, so to ensure an adequate data base, I extended the study over a six-year period from 1988 to 1993.

2 "Active Membership" is defined in this study as "regular attendance at worship services amounting to at least two Sabbaths a month, and involvement in the church in at least one other area. 
meeting." For the purpose of this study, "evangelistic meeting" includes any publicly held full-message seminar, whether conducted by a pastor, lay person, or visiting evangelist.

The churches range in size from twenty-five to one hundred members. Some phone calls had to be made to check the data gained in the study, but in general the clerks showed an adequate understanding of the survey process and of the members they were tracking.

Interviews were also conducted in the area. Three pastors of small churches were asked about their churches and districts. Four active church members were interviewed concerning their experiences in their respective churches, and four inactive members were interviewed to seek their experience in the churches where they may attend but do not participate.

The Findings of the Ten-Church Survey

In general, the churches did quite well with the members they had gained, showing an average retention rate of 70.5 percent. This was a figure much higher than rumor had led me to expect.

Some churches did better than others, of course. Retention ranged from 0 percent in one small church to 100 percent by another. Each of these extremes had extenuating circumstances. The church that reported perfect retention baptized only three people in the six years covered by the study. All of these were children of church members and therefore too young to "vote with their feet." Thus it cannot yet be ascertained how well they will assimilate in their later years. The church that had zero retention baptized four persons, and worked hard to retain them, but internal family problems have caused two to remain inactive, and two to be dropped from the books. ${ }^{1}$ (See appendix A for

\footnotetext{
${ }^{1}$ Two transferred out of state to preserve their family and have not yet found a church fellowship they like enough to stay. One requested to be taken from the books after a long spell of mental illness and family difficulties and one became involved in adultery.
} 
detailed results from the spreadsheet.) Table 6 gives the breakdown of the ten-church study.

Table 6.--The summary of results concerning assimilation by church

\begin{tabular}{|c|c|c|c|c|}
\hline Church No. & Church Size & No. Joined & $\begin{array}{c}\text { No. Still } \\
\text { Active }\end{array}$ & $\begin{array}{c}\text { Percentage } \\
\text { Retained }\end{array}$ \\
\hline 1 & 83 & 3 & 3 & 100.0 \\
\hline 2 & 55 & 6 & 5 & 83.3 \\
\hline 3 & 100 & 13 & 9 & 69.2 \\
\hline 4 & 30 & 4 & 0 & 0.0 \\
\hline 5 & 43 & 6 & 3 & 50.0 \\
\hline 6 & 76 & 33 & 26 & 78.8 \\
\hline 7 & 71 & 13 & 8 & 61.5 \\
\hline 8 & 76 & 42 & 34 & 80.9 \\
\hline 9 & 44 & 10 & 4 & 40.0 \\
\hline 10 & 56 & 16 & 11 & 68.8 \\
\hline
\end{tabular}

The method by which people were attracted to the church was also surveyed. This information is represented in three major categories: personal ministries, biological, and evangelism. Sometimes several of these means were combined. In most cases where these multiple influences were reported the members involved were assimilated more easily, by a rate of 91 percent. The figures in table 7 compare the relative effectiveness of the evangelistic method to the assimilation rate or percentage retained in the survey.

Table 7.--Percentage retained compared to evangelistic method

\begin{tabular}{|l|c|c|c|}
\hline \multicolumn{1}{|c|}{ Method } & Total Gained by & Total Retained & Percentage Retained \\
\hline Public Meeting & 36 & 31 & 86 \\
\hline Personal Min. & 51 & 35 & 69 \\
\hline Biological & 57 & 42 & 74 \\
\hline Mixed & 22 & 20 & 91 \\
\hline
\end{tabular}


Please note the following cautions concerning the interpretation of table 7. First, this information was not the primary goal of the survey and was collected as an afterthought. The clerks involved did not always report the route by which a person entered the church. Therefore, since the method of entry was not known for all those reported by the clerks, this is based on only a sampling. One fact that may skew such a sampling toward the positive is that the clerks most likely knew this information for members who were active in the fellowship at the time the survey was taken. Inactive members would be less likely to be known well by the clerks and to have this information recorded. Second, many represented in the survey had several categories listed by their name. They came in by mixed methods. No attempt was made to sort these out from the totals since a person who had a biological connection to a church family, attended an evangelistic meeting, and received pastoral Bible studies was clearly influenced by all three. It is assumed, however, that the percentage column was balanced by the fact that both the total joined and the number retained columns would be inflated to roughly the same degree.

\section{Summary and Conclusions}

As mentioned above, the assimilation rate for these churches was higher than expected. Rumors abound as to how the church sheds members. Horror stories concerning the church that baptized fifty people yet no longer sees any one of them are told frequently. While these things do happen (I surveyed one church in which the assimilation rate for twenty-one new members baptized by an evangelist was only 38.58$), 1$ the stories are probably being retold over and over again at the expense of those churches that achieve far better results.

${ }^{1}$ This information is not a part of this survey because the event occurred earlier than 1988, the beginning year for this study. Even so, the 38\% assimilation was far better than the rumor, which stated that none had been retained. 
The range of assimilation rates for the churches indicated that some small churches are more ready and able to assimilate new members than others. In general, those churches with less than fifty members had the lowest retention rates. Since these are the churches that follow most closely the single-cell model for church life, the reason for this could be that the local fellowship, intimate as it is for those who have had access to it over the years, has a difficult time opening up to newcomers, who have not, of course, shared in its history and traditions. Therefore, although the church invited them into membership, its table was full, all available places in its fellowship having already been occupied.

Since the single-cell structure breaks down at about the fifty member range, the larger congregations will have more places available to newcomers. People are more likely to find a fellowship when there are more tables present in a room.

Still, the church of any size will have its saturation point. There were churches in the survey with close to one hundred members whose assimilation rate was only 50 or 60 percent. This shows that while church size is relevant to assimilation, other factors will also determine whether new members find themselves included or excluded from the hearth fires of the local fellowship.

It would be good to find a way to evaluate how much room a church has within its fellowship that would be open to new believers before plans are made to hold evangelistic meetings. However, since the answer to this question deals with emotional issues such as social structure rather than the more concrete concepts of floor space and seating capacity, getting a viable answer could be difficult.

Regarding the method of entry into the congregation, all methods show that they work, and all have their losses. However, the significant difference between the assimilation rates for those who came 
into the church through just one major route and those who came in through several approaches suggests the wisdom, when possible, of pursuing a multi-pronged approach to evangelism. One of the advantages could be that those who have had personal studies and then sit through an evangelistic series have had longer to adjust themselves to the new truths presented. Also, the local church has had more time to get used to that new individual in its fellowship.

\section{Findings from the Interviews}

\section{Pastoral}

Interviews were conducted with three pastors in central Pennsylvania concerning their experience in assimilating new members. Twenty questions dealt with six items for each pastor: demographic information (see questions 1-7 \& 9--this questionnaire appears in appendix B), theory on assimilation (questions 13, 15-17), plans for assimilation of new members (questions $9 \& 10$ ), church's behavior toward new members (questions $7-12,14,18,20$ ), attitudes on responsibility for assimilating new members (questions 14-16\&18), and what is personally being done by the pastor to assimilate new members (questions $9,16,18 \& 19)$.

With respect to church and pastoral demographics, all pastors held responsibility for two church districts. Their tenure as pastors ranged from eleven months to seven years in the district, with from three years to sixteen years total in the ministry. The churches served ranged evenly between family-cell churches and pastoral, but only one pastor could clearly identify the patriarch or matriarch of his congregations. Each church had some identifiable groups within it, giving it the potential for absorbing new members, but most of these groups were considered by the pastor to be closed to outsiders (family or tightly knit friendship groups). The number of open groups in a 
congregation generally fell well below the suggested six to eight groups per one hundred members spoken of by Schaller. ${ }^{1}$ Nevertheless, some of these churches showed high assimilation rates in the six-year study, leaving one to consider whether or not the pastor was aware of all the openings into his church fellowships. The pastor of two of these congregations answered question 20 of the interview, "Are new members to your church staying active. . . ?" with a "yes" and indicated that they had all moved into leadership positions in the church.

All of the pastors showed an understanding of the needs of the new members who had come into their folds, and each had an idea as to why they sometimes left. The majority felt that new members needed friendship and acceptance in an environment free from criticism in order to remain strong. Two also felt that they needed to be given responsibility in the church fellowship so that they could feel a part of the program. The youngest pastor also mentioned that the new member needed to learn to apply the gospel to his or her life to become "other centered."

These pastors believed that there were multiple reasons why new members sometimes leave active fellowship. In ranked order these are: an inability to find friends and involvement in the church program (2), 2 a lack of true conversion--they are converted to doctrines, not Christ (2), screening on the part of the congregation (2), the decreased attention they receive after baptism discourages them (1), criticism by church members (1), and church members who fight in front of them (1). What is needed then to assimilate the new believer? All believed that helping the new member to find friends in the congregation was very important. Involvement in the congregation was second in

\footnotetext{
${ }^{1}$ Schaller, Assimilating New Members, 95.

${ }^{2}$ The number within parentheses indicates the number of responses to a particular item.
} 
importance. One pastor also felt that being honest and truthful with them (both in teaching and in social interactions) helped also.

One interesting response, from question 15, dealt with who

pastors believed were responsible for assimilating new members. All of them placed some responsibility upon the local church fellowship to open itself to new believers, but two of the three pastors indicated that the responsibility needed to be shared equally between the new believer and the congregation. The thinking here is that the new believer needs to care enough about church involvement to push through the social barriers confronting him or her, even as the church members need to care about growth enough to lower the barriers.

The third area examined was whether or not churches have any concrete plans by which they can involve new members in their fellowships (9 and 18). In short, the questions are: "How do you encourage visitors to return?" and "Do your churches have a plan for helping new members become a part of your church fellowship?" Amazingly, the answer from all three pastors for all of their small churches was "No." Churches had no formal plan in this area. This indicates that anything positive that is taking place in their congregations with respect to assimilation is happening on an informal basis only.

One pastor mentioned that he was planning to implement plans in his churches in the coming year. He has been in the district he serves for only eleven months. If he is successful in his plans, he will be the only one of the three to develop assimilation processes as a formal means of integrating new members and welcoming visitors.

Church behavior toward new members was the fourth area to be analyzed. In integrating new people into any congregation it is necessary to have places to put them. All pastors reported at least one open group that would welcome new members in one of their churches, but 
two of them served churches in their district that had only closed groups (family or closely knit friendship groups). Coupled with the already mentioned lack of a conscious church-wide effort to make visitors and new members feel welcome, this fact shows why it is often difficult for new people to find a niche in existing congregations.

When asked what experience they felt new members would have when attending their churches for the first time, all three pastors gave variations of the same response. They would be greeted at the door and perhaps informally by one or two members. They would be given directions to Sabbath school classes for themselves and their children. One or two might even be invited home for a meal (one pastor mentioned). But that was the extent of the church's effort.

When asked to place themselves in the position of a new member attending their church for the first time, the two pastors who felt they could answer the question indicated that they would be impressed by the friendliness and hospitality of the members and the nicely kept buildings. However, when asked if they would be likely to return, they were indifferent. Two pastors said the chance was fifty-fifty that they would return, and another commented in the negative: "I would not feel a burden to go elsewhere." The negative phrasing indicates that while he would stay he was not excited about doing so. It is interesting that, although all pastors considered their churches friendly, they did not find them friendly enough to really get excited about. If the pastor is not excited about what might be encountered at his church, what of the members?

Pastoral perception concerning the past staying power of new members at their churches varied considerably. The newest pastor was able to say that new members in his congregations were staying active. In his congregation, the church clerk reported an 80 percent assimilation rate over the past six years. Another pastor felt new 
members remained somewhat active, but some have fallen away, and that fact has depressed some of those who have remained. Interestingly enough, in the clerk's report on his church, over 60 percent of those baptized in the last six years had drifted into inactivity (the present pastor had only been in this district the past $21 / 2$ years of that study). One pastor evaded the question as to whether new members were staying active, saying that his church involved them. In his congregations all baptized in the past six years were the result of biological growth within the congregation and therefore were a part of their church family groups already. They will certainly stay active until they leave their families. Therefore it would be hard to determine in the case of his churches whether new members resulting from true kingdom growth would stay active or not.

One encouraging finding in the interviews concerned who the pastors believed were responsible for fellowshipping new members. All of them recognized that new members will need a lot of friendship, acceptance, and encouragement. One also understood that they would need further training in the distinctive truths of our message as seventh-day Adventists. All the pastors believed that the entity responsible for providing for these things and assimilating new members into the church fellowship was the church itself. They could see that only the church body was able to open its arms in welcome to newcomers.

In spite of this, however, two of the pastors believed that the newcomer has as much responsibility for his or her assimilation as the church body has. Pastors believe that the new member needs to keep trying to get in and not back down if everything does not work out the first time he or she seeks admittance. The newcomers need to make themselves available to the church for assimilation by responding to the church's efforts to involve them, not by sitting in the pews with arms 
folded and life closed to the hospitality of those who are trying to help them.

The final area of inquiry was to determine what is being done in the church to assimilate new people right now. I have already pointed out that none of the pastors had churches with a plan to aid the assimilation of new members. All the pastors indicated, in response to question 19, however, that they themselves were accustomed to doing the necessary footwork to incorporate new members into their churches. Two pastors involved themselves in visitation, prayer, and personally inviting new members to events and programs. One pastor personally encouraged church members to befriend the new members and invite them to take part in their fellowship groups. The other pastor felt that new members needed to be inoculated against the criticisms and imperfections of the church they were joining, so he would spend time before baptism discussing the ills of the church as well as its good points. In this way he hoped to expose them beforehand to the types of behavior they may encounter and so fortify them to keep trying to enter the life of the church after they encountered its more negative points.

\section{Member Interviews}

The active and inactive members interviewed are considered together so that comparisons and contrasts of their views can be more easily presented. Members' interviews also dealt with six areas of inquiry. First, demographics of the members and their church were considered (questions $1,3-7,17-18$ ). The second area sought to determine how aware the church members were of the assimilation needs of new members among them (questions 8, 9, 13, 15-20). The third area sought to determine the members' involvement with assimilation processes in their churches (questions $15 \& 20$ ). This was followed by the behavior of the church with respect to assimilation of new members 
(questions 9-12, 16-18). Questions 16 through 18 also ask "Who is responsible for assimilating new members in your congregation?" Finally, the interview explored what each member was looking for in a church home (questions $2,4,5,14,16$ ).

Regarding the background information on each interviewee, it was found that both the active and inactive members had been members of their particular church from between two years to over a decade, thus both recent and long-standing members were involved in the data. As expected, those who were active indicated that nearly all the members of the church were their friends. This was also true for two of the inactive, although they had been charter members of their church. The younger two (in terms of time in the particular church) indicated that they had only a few church friends, with more on the outside. All active and three of the inactive members had held major church offices. The remaining inactive member had never held any office. The holding of church office in the history of the members seems not to bear heavily on whether they are active or inactive.

Involvement in groups in the church was one of the strongest indicators of difference between active and inactive groups. The active are involved in at least one group, while the inactive are not. If the church were to create abundant groups, would it be possible to help inactive members become active in one such group, and thus change their whole orientation?

Most of the active members were in a pastoral church or higher designation. The inactive members almost always belonged to a familycell-group church organization. Generally, this is expected, for the pastoral church has more groups likely to assimilate people.

Similarly, most active members did not perceive decision making on the part of the church as being dominated by any one person. Active members perceived the church board as representing them in making its 
decisions. However, inactive members perceived one person dominant in the church, whether the pastor or a matriarch or patriarch. All inactive members did not consider this to be a bad thing however, especially if the person was the pastor. Two were, however, disgruntled at the way decisions were being made by this one person.

Another contrast was revealed in the members' perceptions of the church's evangelism with respect to assimilation. Active members felt that new members tended to stay in the fellowship (some more than others), but those inactive members who answered said they were all dropping out. However, when asked if someone in the church made the decision on who was welcome to stay and who to leave, the group was divided. No active person felt anyone would individually chase people away, although two felt that the congregation, as a whole, might screen them out. The inactive people showed more willingness to believe in such a person. Fifty percent stated that they felt that someone made the decision about who was welcome and 50 percent did not. This may show a feeling of victimization present among the inactive directed against the active members in their church family. If so, however, their answer to question 9 is puzzling. There they agreed 100 percent with the active members that their church was open to new people trying to join it.

Member awareness of the assimilation needs of new members begins with a definition of what an active member is. Both active and inactive members agreed that active members would be involved in the church in more ways than just worship attendance. All felt that when new members came into the church it was the church membership as a whole that was responsible for assimilating them and making them feel at home. Indeed, most of the inactive members said they felt at home in the church right away, or did so within a short time of joining, just as the active members did. Only one inactive member felt otherwise. 
When asked why they felt many new members drop away from active church fellowship, some differences of opinion arose. Active members tended to feel that fellowship and nurture were lacking and this caused new members to leave them. However, this area was not even mentioned by the inactive members. Inactive members believed that outside pressures were responsible for many people falling away. Only one active member mentioned this problem. Fifty percent of the inactive also felt that many who were baptized were baptized too soon. They were not ready to believe the message and live it. The plea here was for more time for growth in the new member's life. Only one active member mentioned this concern. Two active members felt that the problem was that the church preaches high standards but does not live them. One inactive member agreed, saying that there are mixed messages due to the lack of a uniform teaching throughout the church.

Thus, in order to incorporate new people into the church, active members and inactive members see some things alike and some issues differently. Getting new members involved was mentioned far more often by active members, 75 percent of whom believed this was important. This compares to 50 percent of the inactive who also believed this. Active members and inactive members felt equally positive about having a "spiritual guardian" program to help new members into fellowship and friendly social interaction inside and outside the church. However, active members were mistaken in thinking they should keep new members out of church office for their first year. Inactive members felt that it was important to accept newcomers, even if they have not fully adopted all the standards yet. They emphasized giving new members time to grow and being honest about our own struggles in these areas when talking to them. They perceived self-righteousness as a definite problem in some church congregations. Active members did not mention these concerns. 
Another great contrast between active and inactive members concerns the perception as to whether people are assimilating or leaving active church fellowship. The active members reported that all stay active (one response) or some stay active (two responses), pointing out that new members who join a group become involved in the church life. The perception is totally different among inactive members. They believe that nobody stays ( 3 with 1 abstention).

Active members reported individually that they do what they can to encourage new members to stay and become active: they encourage them when they can, bring gifts, write them letters, and greet them informally at the church services. The inactive members do nothing, except greet the person if they happen to be at church that day.

This places a fair estimate on the personal involvement of the membership in assimilating new members. What they do is helpful, but their commitment needs to deepen. The respondents leave the impression that their personal involvement is almost always limited to the church premises. Nothing listed above really invites new people into the members' own corner of church life. It seems that while members recognize that it is their responsibility to help new believers into the fellowship, they do not understand what that really means in terms of personal effort on their part.

Perhaps this is why, in noticing how the local church behaves around new members, one inactive member, while admitting to the friendliness in the congregation, pointed out the shallowness of it as well. The active members believe that their fellowship is excellent. They were impressed with the friendliness of the congregations they attended and the people willing to help in the program. They are not aware of any failing in the fellowship they enjoy. But two of the inactive members mentioned that, for them at least, the smiles stopped at the eyes and the handshakes were limp. This indicates either 
screening behavior on the part of the church or unrealistic expectations on the part of the inactive member concerning what the church members should do to help them feel involved.

Most, when asked if they would return after the first visit, would do so. But the inactive members tended to qualify their statements. They would stay if the message was right or they would stay if the fellowship was good, or they would return if welcomed. Since they are inactive in their present fellowship, this may indicate why they are not getting involved: because the message was not for them, the fellowship was lacking, and they did not feel welcome.

The fifth area looked at was the perception of responsibility for incorporating new members. It has already been mentioned that both active and inactive members believe that the church bears the primary responsibility here. Yet, the active member seems not to see what the inactive member is all too aware of: that there are some in the church who make newcomers feel unwelcome so that they do not return. If indeed it is the church's responsibility to integrate new members, it is also the church's responsibility to deal with those members who destroy the will of new members to attend and support the church.

What do people look for in a church? Active members state: friends and acceptance, friends and learning, and obedience to the Bible. Inactive members also show a high degree of will to be faithful to the message, but some are held back from coming regularly by health problems, criticism, and sometimes by hearing false (to them) teaching in the Sabbath school.

Active members list further that they come to church for: accepting people, openness, friendliness, dedication to principles of message, children's programs, and conservative values in worship. There is much of "what my church can do for me" in this list. Inactive members also seek church service. In order, they desire a sense of 
belonging, first of all, followed by reverent worship, a pastor who preaches a true message, and an active outreach program. With this list, one wonders why they are not active. Perhaps, however, they find it hard to be active alone, and so they sit on the sidelines waiting for a church that will lead out in some of these things.

\section{Summary of the Interviews}

The pastors surveyed showed that they had an awareness of the need for assimilation within their churches, and an awareness of the need for the church to become more friendly and open to new members among them. They aiso acknowledge the importance of groups in their fellowship and how this can help new members find a place. Each was involved, pastorally, in attempting to make the new members a part of the fellowship of the church they were joining. However, none of these pastors seemed to have the wholehearted support of their congregations in this task. None had been able, at present, to implement plans by which the membership would welcome and incorporate new members into their inner fellowships.

The active members showed some awareness of the needs of new members. They understood that the burden of responsibility for fellowshipping them rested with themselves as the church membership. However, their satisfaction with the church fellowship as they knew it made it hard for them to see why new members do not always feel a part. Their concept of fellowshipping is to greet them at church and write them letters. Far more is needed.

There were numerous comparisons between the active and inactive members. They both felt that their churches were friendly and open to new people, at least at first glance. They agreed that fellowship is important in choosing a church. They had almost all held office at one 
time or another. All agreed on the church's responsibility to build up the fellowship.

However, inactive members have a different perspective on how successful the local church has been in providing these things. They see most of the new members dropping into oblivion, whereas active members think they are still active. They are more likely to have felt screened out of the fellowship by one or two powerful people, whom the active members seem unaware of. They see that certain decisions are made only when certain people approve them. Moreover, inactive members are far more likely than active members to sense the need to allow new members time to grow into the message they have adopted, and they feel the slight of those members of the church who seem self-righteous in that they are quick to criticize anything that deviates from the norm. A look at the literature concerning small churches and the dynamics taking place in their fellowships will be of benefit in understanding these differences in perception.

\section{Literature Review on Assimilation in Small Churches \\ The Shrinking Church in North America}

George Barna points out that "America represents one of the great untapped mission fields in the world today. [It is]. . one continent on which Christianity is not growing." ${ }^{1}$ While things are not as pressing for Seventh-day Adventists as perhaps others, figures show that the rapid growth seen in developing nations far outstrips the slowed growth rate in North America. ${ }^{2}$ This news would be even more disturbing if it took into account the number of persons who join the

\footnotetext{
${ }^{1}$ George Barna, User Friendly Churches: What Christians Need to Know about the Churches People Love to Go To (Ventura, CA: Regal Books, 1991), 191.

${ }^{2}$ F. Donald Yost, "Seven Adventist Trends: Statistical Profile of a Changing Chruch," Dialogue 2, 1990, 10.
} 
church and fall away from active membership but still retain their names on local church books.

We are not doing well in reaching or retaining the present generation of North Americans known as "baby boomers:" Sixty-two percent of those who have fallen away from our church rolls are from this thirty- to forty-eight-year-old age group. ${ }^{1}$ As researched by Brad Strahan in 1989 , it was noted that the most important factor in having a "high level of satisfaction with the church" was found when there was a sense of togetherness in the congregation. ${ }^{2}$ Small churches could have a real advantage here in dealing with this need for togetherness, if they would.

The Unique Characteristics of Small Churches

\section{Basic Small Church Structures}

The family church

I have already mentioned that small churches fall into two basic structures according to size: the family and pastoral churches. Arlin J. Rothauge points out that the family church is a one-cell structure headed by a few matriarchal or patriarchal figures. ${ }^{3}$ Carl Dudley adds that this unofficial leadership rests on "time-honored relationships" built of their shared history and struggles in carrying the church during crises. Their support is necessary before any change in the church, including the acceptance of new members, can be achieved. ${ }^{4}$

In small congregations. . . newcomers will probably not feel a part of the group until the matriarch or patriarch of the

${ }^{1}$ Gary Russel, ed. "Why Have All the Flowers Gone?" Reclaiming Missing Members 1 (August 1994): 3.

${ }^{2}$ Brad Strahan, "Adventist Attitudes: A Research Report," South Pacific Record and Adventist World Survey, 13 Jan. 1990, 6.

${ }^{3}$ Rothauge, 7.

${ }^{4}$ Carl S. Dudley, Where Have All our People Gone? New Choices for old Churches (New York: Pilgrim Press, 1979), 81. 
congregation has communicated to the newcomer and the rest of the congregation that this new person is on the inside. ${ }^{1}$

New members coming into the family church have several basic needs. They need information about the heritage and traditions of the congregation, acceptance and recognition beyond what the gatekeeper and church functions can provide, association with the patriarch or matriarch, and safe opportunities to discuss their relationships in their new church family. ${ }^{2}$

The pastoral church

One step higher on the membership scale, the pastoral church shows a somewhat different picture. Roy M. Oswald and Speed B. Leas point out that the single-cell of the family church is divided into two or three cells in the pastoral church, "each of which functions as a clan." ${ }^{3}$ Therefore much of the family church remains in the form of subgroups within the larger congregation. Oswald and Leas further point out that these primary groups are often extended family units, although they can also be groups united about some common interest such as music or a Sabbath school class. The primary difference in the pastoral church is that the matriarchal or patriarchal authority is now delegated to a leadership circle centering in the pastor. ${ }^{4}$

The sand dollar effect. Carl George notes that in this size congregation, the clustering of some members into various primary groups produces what he calls "the sand dollar effect." The term refers to the graphic pattern on the back of a sand dollar where several raised portions are set off from the rest of the shell in elliptical designs radiating from the center. "Like the sand dollar's star embossing, a

\footnotetext{
${ }^{1}$ Rothauge, 32.

${ }^{2}$ Rothauge, 11.

${ }^{3}$ Oswald and Leas, 33.

${ }^{4}$ Ibid.
} 
series of overlapping cliques of people are found within a church durably bound together by past experiences, common interests, and family ties." Members who are not part of these cliques occupy the space between the embossments. They are part of the congregation but are looked upon by clannish insiders as being of marginal value. ${ }^{2}$

Assimilation problems. Any true assimilation into this church must involve developing a relationship with one or more of these cliques and their members. Newcomers who do not "make the proper alliances and friendships with members of one of the cliques" will probably feel unwanted and drop away. ${ }^{3}$

Like the family church before it, the insiders in this size congregation will probably think that they have a friendly church, for among themselves "they comfortably minister to one another." They are not aware of their "institutionalized neglect for the marginal people" in the church body. ${ }^{4}$ This again is the behavior John Savage calls "screening," $"$ and bars growth in any church fellowship.

\section{Basic Small Church Culture}

In speaking of the small church experience Anthony Pappas writes: "They were operating out of a different system . . . with different values, perceptions and understandings." ${ }^{6}$ He shows that their viewpoint differs significantly from that of larger congregations.

${ }^{1}$ Carl F. George, Prepare Your Church for the Future (Grand Rapids, MI: Fleming H. Revell, 1992), 65.

${ }^{2}$ Ibid., 66.

${ }^{3}$ Ibid.

${ }^{4}$ Ibid.

${ }^{5}$ Savage, Mitchell, and Nelson, Lab I Leader's Guide, 6.

${ }^{6}$ Anthony G. Pappas, Entering the World of the Small Church: A Guide for Leaders (New York: Alban Institute, 1992), 4. 
Some basic small church differences

Lyle schaller notes more than twenty of these differences, among them several that relate to fellowship. ${ }^{1}$ He points out that the primary focus of the small church is the health of each individual member, whereas the health of the institution is foremost with larger churches. ${ }^{2}$ The small church can feel satisfied year after year with regular attendance at worship even though only a fraction of the pews are occupied, while larger churches would be depressed by this. ${ }^{3}$ Bloodlines ${ }^{4}$ are "very influential in selecting officers" in small churches, whereas talent guides larger congregations. 5 "Thousands of small membership churches act on the premise that the office can mold the person." 6 This leads them to ask members to fill offices who may not even be in regular attendance because "it may help them become active again." In larger congregations, members earn their place. ${ }^{8}$ The death of a member in a small congregation is the death of a friend, not a statistic. ${ }^{9}$ Small churches have little patience for formal planning processes ${ }^{10}$ (which is one of the factors that played havoc with the movement to bring $\mathrm{MBO}^{11}$ to the small church in 1980). Furthermore,

'Schaller, The Small Church Is Different, 19-40.

Ibid., 19.

3 Ibid., 20.

${ }^{4}$ Pappas points out that: "People who come from a long line of very active and committed church members are more likely to be chosen at a relatively young age for irmortant leadership positions than members who do not have the benefit of good bloodlines." Ibid., 21.

${ }^{5}$ schaller, The Small Church Is Different, 21.

${ }^{6}$ Ibid.

${ }^{7}$ Ibid.

${ }^{8}$ Ibid.

${ }^{9}$ Ibid., 23.

${ }^{10}$ Ibid., 24.

${ }^{11}$ MBO means "Management By Objectives" and was tried as an across-the-board program in most Adventist congregations in North America in the 1980s. In small church congregations in Pennsylvania, where I pastor, it was 
the small church is "owned and operated by laity," "cares more for people than for performance, " 2 "is intergenerational, " 3 "relational," and runs by its own "internal clock" and "calendar" (two of the most frustrating things a new pastor may face). ${ }^{6}$ One of the nicest things about the small church is that it "has a place for everyone." One of its more problematic features is the importance given to "kinfolk ties." ${ }^{8}$ (This latter item creates a shell that is hard for newcomers to penetrate.)

Anthony Pappas explains why most church literature is irrelevant when applied to small churches.

The thought/action system of the small church varies significantly from that of other institutions. We may call the thought patterns of small church people a "folk mentality," for it is closer to the thinking of people in "folk societies" than

tolerated, but never fully adopted. It is an example of a program that is designed for large congregations, but which does not meet the thinking of small membership church groups.

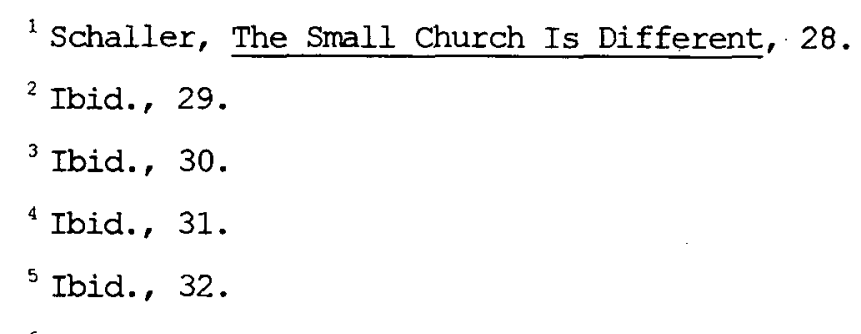

${ }^{6}$ I say "frustrating" because it is quite cormon for the pastor to be waiting to begin a service or a meeting and find that everybody arrives 15 to 30 minutes late. The scheduling mechanisms in small churches run by convenience to the people and their traditions, not by externally imposed clocks or calendars.

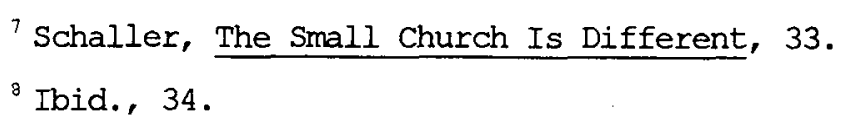

${ }^{9}$ Pappas points out on p. 9 of his book, Entering the World of the Small Church, that a folk society is a group of people who: (1) are small in number, (2) have long association over time, (3) know each other well, (4) have a strong sense of belonging, (5) are isolated from other groups, (6) identify strongly with their territory, (7) are "in a little world by itself," (8) tend to consider advanced age as synonymous with wisdom, prestige and authority, (9) have gone through similar sequential experiences, (10) have simplified rolls, (11) emphasize oral over written commications, (12) have a straightforward technological level, (13) determine the position of the individual according to rights and duties in the society, (14) have both expressive and effective behavior, (15) consider relationships to be ends in themselves, not as means to a goal, (16) are motivated by social recognition not personal gain, (17) prize stability above change, (18) allow traditions to determine their actions, and (19) find moral worth in doing things the traditional way. 
to the thinking of people in complex, bureaucratic and abstract organizations. ${ }^{1}$

A folk society roughly equals a tribe or a clan. ${ }^{2}$

Three characteristics of folk societies

Pappas lists three characteristics of tribal, folk societies. First, "roles more than offices determine the social landscape." ${ }^{3}$ This means that the matriarch or patriarch will determine the course of the church program more than an elder would. The person who fulfills the gatekeeper role in the church may not be the one stationed to greet people at the door. "The important thing to remember is that it is these types of roles which are really important not the rational structuring which pastors usually think is important."4

second, "what holds a tribe and a church together is commitment not favorable cost-benefit ratios."s People have placed their very lives into the church and see their security as a part of a secure whole. They will keep the organization going regardless of the treasury because of the social covenant they have made with one another. ${ }^{6}$ This makes small churches incredibly tough survivors.

A third characteristic is "the priority of social connections."7 The fellowship of the church family is to be protected and preferred above friendships with "outsiders," who may be perceived as the enemies rather than resources. ${ }^{8}$

The outsider is an enemy almost by definition. Not knowing who we are or how we do things puts the outsider beyond the history

\footnotetext{
${ }^{1}$ Ibid., 17.

2 Ibid., 9.

${ }^{3}$ Ibid., 13.

"Ibid.

${ }^{5}$ Ibid., 13-14.

${ }^{6}$ Ibid., 14.

7 Ibid.

${ }^{8}$ Ibid.
} 
and social interaction which gives meaning to the tribal world and its members. The outsider is an alien presence, like a pebble in one's shoe, irritating, a deviation from the correct order of the world. How often are first time small church pastors puzzled by the lack of enthusiasm in the congregation for their evangelization plans and the frequent outright dismay when they succeed in bringing new people in. It is not only those new folk he brings into the church who are outsiders, but even the pastor himself who is initially, at least, an outsider to the ways and mores of his small church. ${ }^{1}$

In a world that wants to have "tomorrow look like yesterday," that values "continuity over time" above "keeping options open," and where the main focus is inward rather than toward the outside world, this is a logical and protective phenomenon. ${ }^{2}$

\section{A different worldview}

Members in a small church have a different worldview. They "[see] the world as a totality." 3 In it everybody knows everybody else by name and family, and social and occupational connections. People are thus integrated into the whole picture. ${ }^{4}$ Any gap in this understanding must be filled in immediately in order for people to feel complete.

Therefore it is common for any gathering of the church, whether business or pleasure, to be filled to a large extent with "catching up" on each other's lives (another frustrating event for the pastor trying to complete an agenda at business meeting time).$^{5}$

Different perceptions of time

Time is perceived as being cyclical in the small church rather than linear in nature, as a larger congregation might perceive it. ${ }^{6}$ Larger congregations plan for the future. Time is going somewhere, to

\footnotetext{
${ }^{1}$ Ibid.

2 Ibid., 14-15.

${ }^{3}$ Ibid., 17.

${ }^{4}$ Ibid., 18.

${ }^{5}$ Ibid. , 19.

${ }^{6}$ Ibid., 41.
} 
something new. "For small church people the course of history is not so much directional as it is repetitive." ${ }^{1}$ Time is marked by what happens in it, and what happens has happened before. ${ }^{2}$ But the first time it ever happened was the best, ${ }^{3}$ the golden time. The orientation to the past thus developed makes it necessary for any change in routine to be anchored positively to "similar initiatives that went before."

A different perception of space

As time is perceived differently, so is space. Space is seen in accordance with what can happen in it. Therefore, physical dimensions give way to personal dimensions. "Space in the small church can never be dealt with only quantitatively. It also has a personal and therefore a sacred dimension." 5 Therefore, when someone new comes into church and sits in a space traditionally occupied by one of the members, the member feels displaced from what is rightfully his or hers, and resentment can smolder for the interloper. Trying to rearrange the Sabbath School classes to give more room to the juniors can likewise meet with resistance and resentment.

Problem perception

Since the small church is a socially structured organization, it sees problems in relationship to its human dimension. Pappas writes:

In a socially structured organization, . . . problems are registered as dissonance also, but not dissonance with the goals of the organization, for this organization has no goals. . . . Rather dissonance is registered when it occurs between the present state of things and how they used to be (when they were right). Problem registration, then, is not objective, nor is it subject to qualitative indices (except in very broad terms). It

\footnotetext{
${ }^{1}$ Ibid.

${ }^{2}$ Ibid., 42.

${ }^{3}$ Ibid.

${ }^{4}$ Ibid., 42-43.

${ }^{5}$ Ibid., 43-45.
} 
is a subjective sense, a feeling that things aren't right, a

loss of congruency, a mismatch between experience and memory. ${ }^{1}$

of course, the result of this "dissonance" is a desire to get back to the "way things were before," when the dissonance did not exist.

Therefore it fuels a flight into the past, which is the typical

orientation of the small church. If the source of dissonance is a new person who is trying to get into the social group, the flight will most likely be away from his or her presence and will result in screening behavior.

\section{Member Involvement}

One of the positive aspects of being small is that it demands a greater degree of member involvement in the program. Edward K. Perry, one-time president of the Upper New York Synod of the Lutheran Church of America, notes that people need to feel needed, loved, and wanted in their congregations. ${ }^{2}$ Allan $W$. Wicker, ${ }^{3}$ in a study of small churches ${ }^{4}$ using Baker's behavioral setting theory, ${ }^{5}$ points out that most small churches are undermanned, and members in undermanned organizations are

${ }^{1}$ Pappas writes that the goals of the socially structured organization are different from most organizations. Its goals are "frequently below the level of awareness" and involve "continuity over time [survival], congruity of behavior [maintaining the status quo], and recapturing the Garden of Eden [return to the good old days]." Ibid., 26.

${ }^{2}$ Edward K. Perry, "Learning About Fishing in Upper New York" [Photocopy], a paper by the president of the Upper New York Synod, Lutheran Church of America, April 1975, 9, Library, Lutheran Theological Seminary, Gettysburg, PA.

${ }^{3}$ Allan W. Wicker, "Assimilation of New Members and a Small Church," Journal of Applied Psychology 55 (1971): 151.

${ }^{4}$ Wicker was studying churches in the 300 to 600 membership range. Such churches would be considered large by Adventist standards. I believe the conclusions he reaches, however, are valid for he is comparing these churches with even larger institutions, preserving the relationship of small to large on the continuum. If they hold for such large groups, they hold much more for the 50- and 100-member congregations. What wicker could not study in such large "small churches" is the culture of the 50- and 100-member congregation, which is different.

${ }^{5}$ Baker's Behavioral Setting Theory states that the "behaviors and experiences of members of voluntary organizations are influenced by the degree to which the organization's activities are undermanned." Wicker, 151 . 
more likely to recruit others, share responsibilities, and even lower the requirements for admission. ${ }^{1}$ This leads people to experience greater fulfillment in small church functions. ${ }^{2}$

The downside of this would be that undermanned organizations like small churches must necessarily concentrate their efforts on maintaining the church program rather than outreach. This is a condition that Robert L. Bast points out will put the church at a disadvantage evangelistically. He writes that in gearing for growth, "about one-quarter of the church's volunteer pool should be class two workers." ${ }^{3}$ Churches as undermanned as the small fifty- and one-hundred-member congregation will be less likely to reach this level of evangelistic involvement, since all their energies will be sapped by church structure. Evangelism will have to be a second job description carried by each member. Perhaps this is part of the reason why the up to one-hundred-member Adventist congregation shows the second highest interest among its members for enrollment in lay training programs (about 338).4

The Choice to Remain Small

Almost any pastor who has experience in the small church will tell you of the apathy he feels from the congregation when the subject concerns "evangelism." The church will go through the motions of calling an evangelist and advertising meetings, yet very few people show up regularly to meet those coming to the meetings. Some churches have

${ }^{2}$ Ibid.

${ }^{2}$ Ibid.

${ }^{3}$ Class two workers are those volunteers who concentrate their energies outwardly, toward the community while class one workers focus their energies inwardly on the church programs and structures. Robert L. Bast, Attracting New Members (New York: Reformed Church in America and Monrovia, CA: Church Growth, 1988), 37.

${ }^{4}$ Robert L. Dale et al., Survey of Lay Leaders: Activities and Programs in 1989, Report 2 (Silver Spring, MD: North American Division Church Information System, 1 January 1990), 14. 
effectively screened away any who present themselves for membership.

This is what is referred to as the "choice" to remain small.

\section{Reasons for Choice}

Fear

Fear of growth is the primary reason for the ambivalence on the part of small congregations. The concerns of the small church vary, but basically the church chooses not to increase in size because of what it fears to lose. Two of these fears are as follows.

Fear of lost intimacy. One of the greatest fears is the fear of losing their intimate church fellowship. Newcomers will dilute the fellowship they enjoy so much." David R. Ray writes: "Some have resisted growing because they assume growth would mean a loss of intimacy and a dilution of power and authority." 2 L. Ray sells and Ronald K. Crandall support this saying: "Often the members see the outsider as a threat to the security of the fellowship, and are unwilling to risk losing what, to them, is the most important support in their lives." ${ }^{3}$

Fear of change. Closely related to this is the fear of change. Robert L. Maner points out that "we fear growth because we fear change and growth is change." Sells and Crandall write:

To grow is to invite change. To grow is to rearrange the tables, to put someone else at the table, perhaps between you and me, so that now I must talk to someone new after all these years of talking to you. To grow is to introduce new persons, new ways, new values. The church as we knew it may never be the same again! For some of us this is more than we can bear. ${ }^{5}$

\footnotetext{
1 Ray, 44.

${ }^{2}$ Ibid., 118.

${ }^{3}$ Sells and Crandall, 17.

${ }^{5}$ Sells and Crandall, 17.
}

${ }^{4}$ Robert E. Maner, Making the Small Church Grow (Kansas City, MO: Beacon Hill Press, 1982), 19. 
Self-satisfaction

What I call "self-satisfaction" comes next. It is the feeling that things are just fine and why change them? Hortop writes that small churches have high need fulfillment for "older long-term members." This sense of satisfaction tends to cause them to forget the other need fulfillment that goes with the gospel commission, namely, to reach the world. ${ }^{1}$ However, Lyle schaller would disagree that the problem lies with the church members or any lack of commitment to Jesus Christ and the gospel, calling the suggestion "nonsense."2

Lay control

One of the things schaller points out as being a problem is lay control. Studies show that the greater the control of the laity in long-established churches, the less likely they are to grow. ${ }^{3}$ This seems to disagree with the principle of lay involvement and the priesthood of all believers, a proven growth concept in Adventist churches. However, Schaller is referring here to the lay tendency in small, long-established congregations to resist pastoral influences for growth. Since long-established small churches have not been able to hire a full-time minister, the lay people have taken the reigns. If their vision is merely to maintain the church as it is, growth will be perceived as an enemy and "outsiders" will be "screened out."

\section{Barriers to Fellowship}

Schaller's structural barriers

In his book Assimilating New Members, Schaller shows that every congregation has barriers within its fellowship that divide the

\footnotetext{
${ }^{1}$ Hortop, 67.

${ }^{2}$ Schaller, Growing Plans, 21.

${ }^{3}$ Ibid. , 18.
} 
congregation into two status groups. ${ }^{1}$ This concept is very close to Carl George's "sand dollar effect" spoken of earlier in this chapter. Schaller writes:

Nearly every congregation has two barriers around it. The larger outer barrier is composed of several methods, techniques and traditions that have the combined effect of keeping potential new members from joining that congregation. . . . Another group of barriers consists of the unintentional exclusionary dimensions of the congregation. Every congregation, by the nature of the people who are members, by its history and traditions, . . causes many people to feel excluded. ${ }^{2}$

To illustrate this, Schaller refers to what he calls the exclusionary circle, which is a circle within a circle (see figure 1). The outer circle represents the total membership of the congregation. The inner circle represents the insiders of the congregational fellowship and is surrounded by a wall. Those on the inside of the inner circle do not see the wall, but it is very apparent to anyone outside of that select group. ${ }^{3}$

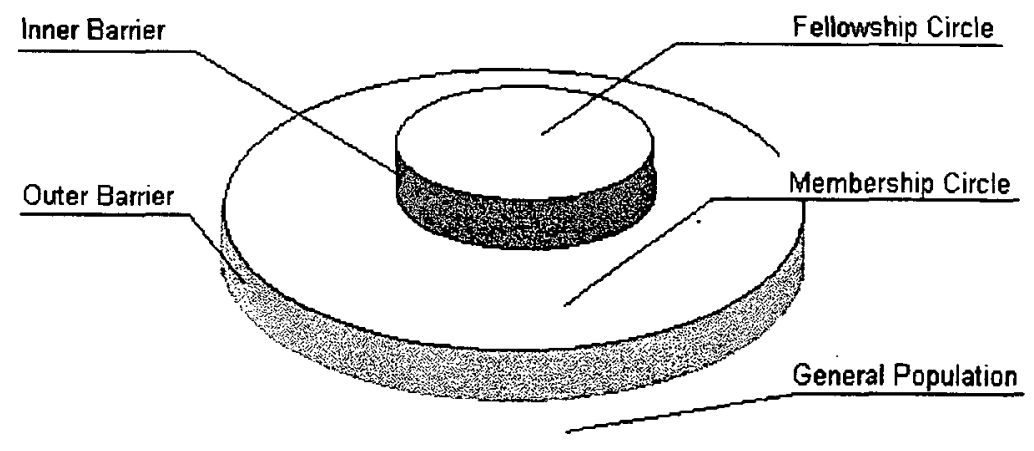

Figure 1. Schaller's concept showing levels of church fellowship.

\footnotetext{
${ }^{1}$ Schaller, Assimilating New Members, 17-18.

${ }^{2}$ Ibid.

${ }^{3}$ Ibid., 80.
} 
The sad part of this situation is that it is possible for persons to leave the general population of the world for the fellowship of the church only to find out that they have become a sort of "eternal visitor." "They may have moved inside of the initial barrier between the church and the world, but still not be admitted to the fellowship circle. Some may wait years for this to happen; others will never be invited in. ${ }^{2}$

Lack of psychological space

One concept that may help us to understand why such barriers exist may be found in the concept of psychological space. In any grouping where people have face-to-face relationships with each other, there is a psychological limit to how many close relationships one person can manage. It is common knowledge that a person can handle a greater number of acquaintances than close friends. Therefore the fellowship circle of any given individual could look much like the illustration above with barriers between friends, acquaintances, and total strangers.

The church structure faces the same psychological limit in its fellowship. Carl S. Dudley writes:

Small churches are already the right size for everyone to know everyone else. They are, in fact, much larger than many social scientists think that they "ought to be." They cannot include more members without letting go of the contact they now have with the present body. In a word, they are "stuffed."

There is only so much room around the table, and it is reserved for those who have already established their place there.

\footnotetext{
${ }^{1}$ Maner, 40.

${ }^{2}$ Ibid., 39-40.

${ }^{3}$ Dudley, Unique Dynamics, 13.
} 
Mental chains

Maner points out that there are also psychological "chains" that small churches impose upon their own thinking with respect to growth. ${ }^{1}$ One of these is "smallness." This involves a mental limit that he considers to be self-imposed so that a change of mind in this respect could produce a change of size in the congregation. David R. Ray, in his book Small Churches Are the Right Size, writes: "They can use their small size as an excuse for inactivity and mediocrity." 2 Another such limit, Maner counsels, involves the church's denominational label. Some may feel that their church does not grow because it has a certain denominational affiliation, but Maner points out that this is fruitless thinking. It is what we do, not what we are called, that restricts our growth. ${ }^{3}$

Another chain involves the church's concept of the pastoral role. In many small churches the pastor does it all. He is "priest, prophet and errand boy." Such a concept limits any growth in the church to what the pastor can accomplish, and sometimes the "errand boy" aspect of this can be so limiting with respect to his time and energies that little space remains in the pastoral schedule to reach out to new people and bring them into the church fellowship.

There is also an inferiority complex in small churches that results in a tendency to make excuses for inactivity. It sounds like: "The other church grew because. . . but we don't because..." The truth is that everyone struggles the same when it comes to growth. ${ }^{5}$

\footnotetext{
${ }^{1}$ Maner, 22.

2 Ray, XV.

${ }^{3}$ Maner, 22 .

4 Ibid.

5 Ibid.
} 
The final chain, and perhaps most paradoxical when considered in comparison to the chain of inferiority mentioned above, is spiritual pride. "It is possible for members of a small congregation to draw self-righteous robes about themselves and almost dare a visitor to come among them." Then, when they have thoroughly frozen out their new prospect, they say that the person left because he or she could not accept the "high standards" of the congregation. ${ }^{2}$ There is an "endless list" of items that can be used as excuses under the title, "unpopularity of holiness."

The cost of growth Schaller points out that it is often the congregational perception, conscious or unconscious, of the cost of growth that holds up the evangelistic program. He lists five of these that need to be addressed. First is the loss of intimacy already mentioned. The small church enjoys a closeness that will be diluted as it grows. The second part of the price tag is loss of influence, which will effect the motivation of the present church leadership, for it is self-evident that new members will want to have a voice in church leadership. Third comes loss of comfort. This is related to the loss of intimacy. The church no longer gives the feel of "a well-tailored garment" but is continually having to readjust itself to fit a greater variety of thoughts and needs. Fourth is the risk of failure. Fifth, since new members do not come to us "washed and sanctified," there is a squeamishness concerning the "dirt" they may trail with them into the cleanly wiped church pews. ${ }^{4}$

\footnotetext{
${ }^{1}$ Ibid.

2 Ibid., 19.

3 Ibid.

${ }^{4}$ Schaller, Assimilating New Members, 85-90.
} 
The Possible Results of Choosing Not to Grow

It may not be pleasant or popular to consider this, but unless churches confront these costs and choose to do whatever it takes to promote growth among them, the result could be institutional suicide. Hollis L. Green, in his book Why Churches Die, points out that many congregations are in decline through holding onto the old ways and do not realize it. ${ }^{1}$ You or I could see indications of this fact by a simple study of our Conference directories over the past five years. How many show the same people being elected and reelected to the same offices year after year, and how many churches show the same name or family name behind the majority of church positions?

Green points out that passivity among the membership of a church and eventual church death result when certain conditions become evident in the congregation. When leaders have been in office for ten to twenty years, and large proportions of leaders are overworked, leaving no time for church responsibilities, the church is in trouble. When more than one half of the membership have older children, are widowed, or never married so that their attitude is "we've done our part," and much of the congregation is afflicted with frustration due to unfulfilled dreams, the church is losing its energies. When the leadership of the church is oriented only in the past, the membership feels powerless to move or change things, and the church feels inferior with a poor image in its community, the church is facing spiritual and institutional death. ${ }^{2}$ Green writes:

Because of the nucleus of committed Christians and the number of average or marginal people that remain involved in the program of the church, the drift in the congregation often goes unnoticed. The first major symptom of the problem is when the same persons are involved in the leadership of most all the activities of the church. 1972), 49.

${ }^{1}$ Hollis L. Green, Why Churches Die (Minneapolis, MN: Bethany Fellowship, 2 Ibid., 17. 
The average and marginal membership of the congregation have little or no opportunity for active participation and drift slowly but surely toward a nominal position.

\section{Growth and the Small Church}

Barna's counsel that "in the context of church growth, imitation is also the quickest route to doom" is well taken where small churches are concerned. Lyle Schaller also cautions that growth strategies designed for a church of one size may not work in a church of another size. ${ }^{3}$ However, what is true of transplanting fully blown programs may not be true for their underlying principles. The small church environment, as with any social structure, is still under nature and its laws, even though those laws may need to be applied a little differently.

Dudley and Cummings's statement that "church growth is found where new members are quickly incorporated into the life of the church"4 will be applicable regardless of church size. But the engineering of a church atmosphere that promotes new member assimilation and incorporation will be different for the small church, with only one to three cell groups into which to bring new people.

Norms

One of the things that will influence this is an understanding of how church norms influence the induction of new members. Since the small church functions as a family clan, or a close grouping of two to three family clans, history and traditions have become a large part of its framework. Loren B. Mead writes on the disparity that often exists between newcomers, who are constantly on watch in their new congregation

\footnotetext{
1 Ibid., 142.

2 Barna, 16.

3 Schaller, Growing Plans, 17.

"Dudley and Cummings, "A study of Factors," 131.
} 
trying to regulate their own behavior to follow congregational norms and practices, and old-timers, who "already live the norms even if they don't realize it." This fact makes it hard for established members to appreciate the difficulty other people face in trying to function according to their foibles. What is needed is for someone already integrated into the congregation to help newcomers by "showing them the ropes"--the secret social routes and passwords used by their congregation. Also needed is the congregational reassessment of their behavior patterns to see what helps and what hinders those newly come among them. "Healthy norms can undergird healthy interactions for years; unhealthy norms can inhibit the organic growth of a congregation." 2

\section{Assimilation}

The "small" advantage

David R. Ray lists three advantages small churches have in respect to fostering assimilation for new members. These potential positives can give it the advantage over even the large, multi-celled congregation.

1. Each person can be known in the small church. ${ }^{3}$ This fact offers those who join small churches a range of intimacy not known in many larger institutions. Ray points out that the small church is free to be what it so clearly is, "an intimate, caring, faithful people, colored by their own zany, peculiar, intriguing chemistry of history and personality. ${ }^{4}$

\footnotetext{
${ }^{1}$ Mead, 72.

2 Ibid.

${ }^{3}$ Ray, 92.

'Ibid., 47.
} 
2. "Each person is needed and does make a difference." 1 As mentioned above, the small church is an undermanned organization that needs to involve everybody in its operation. B. Russell Holt, in Ministry, writes that small churches "can't afford the luxury of very many idlers." 2 This clearly fits into the need of new members to be involved and builds the bonds with established members. ${ }^{3}$ The potential is there for "a more intimate and participatory worship service, individualized and experiential education, the mobilization of a whole congregation in mission." "There is also opportunity for, aside from the intimate family network, "an organizational model that is simple and economical to maintain." All this participation is possible because there are not enough members present to keep the organization moving without seeking to involve every able body in the work of the church. 3. "Each person is part of the family of faith network. "6 Those included in the small church fellowship receive family-style treatment.

In a small church I can experience a sense of family and community, an awareness of the needs and joys of each organ of the body, a feeling of being cared for by people who really know me, the possibility of worship so finely focused that it is appropriate for most or all the people, the chance for all to rehearse their common future, and the opportunity for each person to participate as an actor in the great drama of worship. ${ }^{7}$

According to a paper written by Ralph $\mathrm{W}$. Martin, the experience described by Ray here should be very appealing, for we live in a "high tech-high touch" society where "growing churches have high touch" as one

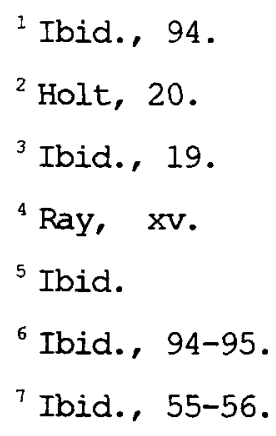


of their primary characteristics. ${ }^{1}$ This means that our increasingly impersonal society leaves people starved for intimate contact. If Martin is right, bringing people into contact with one another in a caring community fills the basic need of our social milieu, and the small church has one of the best answers available to that need.

The small church disadvantage

In spite of these advantages, the small church often finds itself unwilling or unable to move forward in growth. This leads George Barna to write that it is "substantially easier" to plan a new church and have it grow than to revive an "existing congregation that is beset with hardening of the spiritual arteries."2 "Preconceived notions of what the church is meant to be; based on historical precedent," and individuals who have lost their "zeal," "energy," "vision," and "interest" in souls "block the road to growth."

\section{Types of Growth}

A church can enjoy basically two types of growth. There is growth by replacement, and growth as increase. Sells and Crandall interpret these two as follows. Growth by replacement is occurring when a church remains the same size over the years. Twenty years ago it was forty members. It is forty members now, and it will be forty members twenty years from now. This church is growing by replacement only. It is replacing the members lost by attrition (transfer, death, apostasy), but it is not adding any additional members to the group size. The other growth is when you add more members to the group. This is called "growth as increase." It is "growth that comes by extending the size of

${ }^{1}$ Ralph W. Martin, "High Touch in a Depersonalized Society," rough draft of an article for Ministry magazine, 1 March 1990, 1; included in appendix E.

${ }^{2}$ Barna, 188-189.

${ }^{3}$ Ibid. 
the fellowship, adding new members, which increases the total number of active and present members."

Growth as increase involves increasing the number of cells in the congregation and therefore the psychological room available to bring in new members. Single-cell churches grow by gathering people from outside their fellowship and making them part of their fellowship by adoption and some addition. However, they soon hit the limits of their social space (their psychological limit). But for a church to grow beyond these limits, multiplication of cells is necessary. In this the church develops new groups where new members may experience a fellowship that sometimes rivals that of the intimate single-cell congregation. ${ }^{2}$

Some small membership churches, according to Sells and Crandall, find that they share the characteristics of both the single-cell and multi-cell church. ${ }^{3}$ They have room within themselves to accept growth, but people are not coming in to occupy the available seats. Such a church would have to be limited in its growth by some outside circumstance like population loss in the surrounding community.

\section{Assimilation in the Small Church}

Research cited by Joel D. Heck shows that 80 to 90 percent of those who become inactive do so within the first six months of church membership. Heck goes on to say that this is, in a large part, due to a decline in the attention paid new members by the church after they join. ${ }^{4}$ Certainly this gives us a valuable clue to how we can improve our record with respect to keeping new members active.

\footnotetext{
'Sells and Crandall, 13.

${ }^{2}$ Ibid., 16.

${ }^{3}$ Ibid.

${ }^{4}$ Joel D. Heck, New Member Assimilation: Practical Prevention of Back Door Loss through Front Door Care (St. Louis, MO: Concordia, 1988), 17.
} 
The Importance of Friendships

Edward $K$. Perry writes of the need for close friendships in the church, saying: "The key is how people do, or do not, nurture and support each other in the local congregation." In conducting program reviews of Lutheran congregations in upper New York, person after person responded that what pleased them in their local congregation was: "good friend"; "Christian fellowship"; and "people I can depend on."2 Each of these items is friendship-related.

John Savage of L.E.A.D. Consultants teaches that a person's "sense of belonging will usually determine" his or her stay in active membership. ${ }^{3}$ Savage lectures that there are three key issues, "faith, friends and groups," that the church must preserve in order to keep active members active. They are "the glue that holds the church together." Each of the above authors and lecturers considers friendship and fellowship to be primary forces in holding onto church members. Perhaps the reason is disclosed by Nelson Annan, who quotes Win Arn's Growth Report \#1 (dated 1986) pointing to the breakdown of the American family as fueling an increased need for friendship. ${ }^{5}$ According to W. Charles Arn:

Numerous studies in the field of church growth indicate that the most important reason people are involved in their church today is their friendships and relationships. . . . Other studies indicate that persons who become active church members will have identified an average of seven new friends in the church within the first six months. The dropouts will have made less than two. ${ }^{6}$

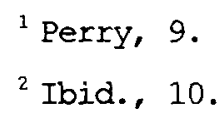

${ }^{3}$ John S. Savage, Kenneth J. Mitchell, and Joyce C. Nelson, Lab I Participants Manual Session I (Pittsford, NY: L.E.A.D. Consultants, 1981), 1.

'Savage, Mitchel, and Nelson, Lab I Leader's Guide, 60.

${ }^{5}$ Win Arn, Growth Report \#1, in Nelson Annan, More People: Is Church Growth Worth It? (Wheaton, IL: Harold Shaw Publishers, 1987), 36.

${ }^{6}$ W. Charles Arn, "Evangelism or Disciple-making?" Church Growth State of the Art, in Roy M. Oswald and Speed B. Leas, The Inviting Church: A Study of New Member Assimilation (New York: Alban Institute, 1987), 58. 
Robert L. Bast reports a study on church dropouts showing that friendships were the key ingredient in bringing people into the congregation and helping them stay active. ${ }^{1}$ Table 8 shows the results of the study.

Table 8.--The importance of friends in the church

\begin{tabular}{cccccccccc}
$\#$ & of & New & Frie nds & in & the & Chu & rch & \\
\hline 0 & 1 & 2 & 3 & 4 & 5 & 6 & 7 & 8 & 9 \\
\hline
\end{tabular}

Status of Member

\begin{tabular}{lcccccccccc}
\hline Active & 0 & 0 & 0 & 1 & 2 & 2 & 8 & 13 & 12 & 12 \\
\hline Dropouts & 8 & 13 & 14 & 8 & 4 & 2 & 1 & 0 & 0 & 0 \\
\hline
\end{tabular}

Robert L. Bast, Attracting New Members (Copublished: New York: Reformed Church in America; Monrovia, CA: Church Growth, 1988), 94.

A study conducted by Russell Burrill on the results of his evangelistic series in Spokane, Washington, shows similar results. There, two thirds of those who remained active, and only one third of those who dropped out, made at least six new friends in the first six months of membership. ${ }^{2}$

Hollis L. Green disagrees, however, with the idea that fellowship is everything. Green argues that it is not sufficient to hold a congregation together without pulpit preaching "to help men find spiritual solutions to spiritual problems."3

However that may be, fellowship is certainly a major factor in bringing people out to listen to the preacher. As Mark Finley points out: "Those who attend a crusade with an Adventist friend are ten times more likely to make a decision to become an Adventist than those who

${ }^{1}$ Bast, 94.

${ }^{2}$ Russell Burrill, "Survey of People Baptized at Public Evangelistic Meetings in Spokane, Washington" [Photocopy], pp. 23-24, NAD Evangelism Institute, La Grange, Illinois.

${ }^{3}$ Green, 144 . 
walk in cold off the street!"1 He further states that the retention rate for this group is 85 percent greater. ${ }^{2}$

\section{The Assimilation Process}

All of the above underline the importance of assisting new members in the task of making new friendships in the congregation. Loren B. Mead urges that "congregations cannot spend too much time developing ways to help the newcomer find her or his way into community." ${ }^{3}$ Socialization needs careful attention and planning to succeed. Mead considers this "a basic issue of the faith."

Four routes to inclusion

Lyle Schaller identifies four routes into membership for adults who have no kinship ties in the congregation they are joining. First are those who were members of a face-to-face small group with congregational members, such as a fellowship group, before joining themselves formally to the body. These were the least likely to become inactive. ${ }^{5}$ Next came those who joined a group in the church where membership in the group was important to them, but they did so after uniting with the congregation. ${ }^{6}$ some became involved in the church through accepting some formal role or responsibility in the church and began to sense belonging. These were a little more likely not to stay. The least likely to retain active status were those who gained their

2.

\footnotetext{
${ }^{1}$ Mark Finley, "Friend-to Friend Evangelism," Update, Sumer/Fall 1994,

${ }^{2}$ Ibid.

${ }^{3}$ Mead, 79.

${ }^{4}$ Ibid.

${ }^{5}$ Schaller, Assimilating New Members, 76.

${ }^{6}$ Ibid.
} 
feeling of belonging only through involvement in an unofficial task as a helper. ${ }^{1}$

Tasks of incorporation assimilation

Bast lists six responsibilities of the local church in seeking to fellowship new members. First, "identify and respond to the needs." People joining the congregation have certain expectations and hopes concerning the fellowship they are entering, but they also come with problems from their past that need to be dealt with physically and spiritually. ${ }^{2}$ Second, the congregation needs to identify itself clearly to the new member as to its "history, tradition, philosophy and goals." This is necessary information for a person who wishes to bond with the congregation. ${ }^{3}$ Third, encourage the new member's concern for the "well-being of the congregation." Membership cannot be meaningful if it is only oriented toward spiritual consumption. People need to give also to the community. ${ }^{4}$ Fourth "help people in the joining process." This can include a class providing an orientation to their new membership and its rights and duties. Questions can be answered and information given that will lessen their anxiety at the change in their lives. ${ }^{5}$ Fifth step is to "prepare people for belonging." Bast considers joining and belonging as being separate issues. "While all members of the congregation know that they have joined," he writes, "not all feel that they belong." 6 This could be the most difficult step in the

\footnotetext{
${ }^{1}$ Ibid., 77.

${ }^{2}$ Bast, 144 .

${ }^{3}$ Ibid., 146.

${ }^{4}$ Ibid., 146-147.

${ }^{5}$ Ibid., 148-149.

${ }^{6}$ Ibid., 150.
} 
assimilation process. Finally, "provide a meaningful experience of reception." Make their public induction a memorable occasion. ${ }^{1}$

Roy M. Oswald, in dealing with the incorporation process, reduces it to simpler terms, beginning with the first visit of a newcomer, and adds the need for raising the quality of life within the congregation as well.

Two things need to be happening simultaneously. Yes, you need to deepen the sense of welcome extended to parish visitors. A thoughtful follow-up needs to be in place. With some clarity the newcomer needs to hear about requirements for membership. These aspects deal directly with the incorporation process. As congregations are trying to clean up their acts on the incorporation process, they also need to be raising the quality of life within the parish. Once newcomers are assimilated into the parish, is there anything of quality to offer them? ${ }^{2}$

The concept of quality of congregational life is often overlooked by those who feel newcomers should expect to "get along with us as we are." Providing an adequate haven for the newcomer to grow in spiritually, however, must necessarily involve improving our own spirituality.

Bast lists the eight characteristics he considers necessary for a member to have if he or she is to be considered fully assimilated into the congregation. Notice the social and spiritual involvement and consider the quality of congregational life these things express.

1. Each new member should be able to list at least seven new friends they have made in the church.

2. Each new member should be able to identify his or her spiritual gifts.

3. Each new member should be involved in at least one (preferably several) roles, tasks, ministries in the church, appropriate to their spiritual gift.

4. Each new member should be actively involved in a small fellowship (face to face) group.

5. Each new member should be demonstrating a regular financial commitment to the church.

6. Each new member should personally understand and identify with the goals of the church.

7. Each new member should be exhibiting a regular pattern of worship attendance.

\footnotetext{
${ }^{1}$ Ibid.

${ }^{2}$ Oswald, 44.
} 
8. Each new member should have identified his/her unchurched friends and relatives and be taking specific steps to help them toward responsible church membership.?

Bast's list suggests that a member who does not exhibit these characteristics may not yet be a fully integrated person in the fellowship. If this is so, we have a lot of work to do.

Assimilation can be thought of as becoming a part of the congregation. In this sense, John Savage suggests that an individual's language change will indicate their feeling that they have been assimilated, regardless of their other involvement. He points out that the pronouns used when referring to the church will change from "your, their, them" to "our, we, us, etc." ${ }^{2}$ I am assimilated when I feel I am part of the whole.

Adoption

A simpler way to see assimilation happening is through the concept of adoption. We all have known families that have adopted children. In terms of the family church, adoption is a useful method of assimilation. Bast writes of the family church: "The process by which newcomers enter is adoption. The crucial need for the new member incorporation process into such a church is for a 'matriarch' or 'patriarch' who will perform that task." As it takes the influence of a parental figure to adopt a child, so the influence of a key church leader is needed to bring in new members to that environment and help them gain acceptance. ${ }^{4}$

Spiritual gifts

According to George Barna, "one of the actions that most clearly separated growing churches from stagnant churches, was the willingness

\footnotetext{
${ }^{1}$ Bast, 137-138:

${ }^{2}$ Savage, Mitchell, and Nelson, Lab I Leader's Guide, 106.

${ }^{3}$ Bast, 126.

${ }^{4}$ Ibid.
} 
of growing bodies to accept people for who they were." 1 By this he means that people should be encouraged to involvement in the area of their spiritual gifts. Spiritual gifts need to be discerned, and then the new member needs to be encouraged to do what "God has called them to do" rather than just plugging them into program gaps. (i.e., in the children's Sabbath school department.) This practice could greatly increase the assimilation of members in local settings.

Development of small groups

closely connected with the above is the understanding that small groups are needed to assimilate new members with any rapidity. Adoption is a one-on-one process and can be properly done only by the primary leadership of the local church. Therefore, it comes up against a bottleneck where growth is concerned. Discovering and assigning places in the congregation according to spiritual gifts, while good advice in itself, need leadership figures to set people in the proper places. Small groups are the ideal answer to the bottleneck problem involved in both processes.

Schaller recommends that in order for a church to assimilate all who might want to join a small group, the congregation needs to have six to eight small groups for every one hundred members. ${ }^{3}$ According to Schaller's concept, a congregation that assimilates well will have "too many fellowship circles to count." 4 These small groups would provide places where new members could be accepted and learn to use their spiritual gifts. They would also involve persons who were not necessarily members of the congregation as yet in fellowship circles

\footnotetext{
${ }^{1}$ Barna, 163.

2 Ibid.

${ }^{3}$ Schaller, Assimilating New Members, 95.

${ }^{4}$ Ibid., 94.
} 
before they decided to join ${ }^{1}$ (and these are the people who assimilate most fully into the church). Schaller recognizes that not everybody in the membership of a church may wish to be a member of such small groups, but the existence of the groups will provide fellowship and encouragement for all who may desire to belong. Joel D. Heck considers that small groups solve the need for new friends in the congregation because small groups help new members to get to know a few people well. ${ }^{2}$

\section{Barriers to Assimilation}

Lyle schaller reports that small churches receive "an average of only four to ten new members a year" and most of those are related to families in the church. ${ }^{3}$ As a result, small churches do not have much opportunity to develop skills in assimilating strangers. In addition to this, the single-cell structure of the small church makes it function as one large group. "New members either are absorbed into that central fellowship or feel left out." ${ }^{4}$ schaller further explains that this large group "is already as large as it can become without changing the character and quality of the interpersonal relationships" it enjoys. That limits growth to replacement growth, for any further increase would cause internal stress upon the existing fellowship. ${ }^{5}$

Such stresses can result in screening behavior among church members toward anyone they perceive as being dangerous to their way of life. If they were to consciously consider this they might justify their behavior with words like those of Arlin Rothauge:

There is a difference between group life and gospel life. The gospel is for all; not every group is for all. As the bearer of the gospel, the church must become a place for all. Perhaps

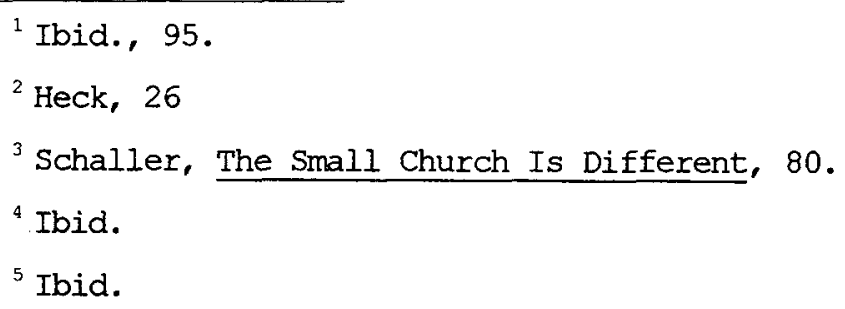


it would be more realistic to say that the church must become a place where everyone can find a place. ${ }^{1}$

As good as this may sound to the ear, it has little place when considering that the single-cell church has only one fellowship group into which new members must be integrated. In that case, Rothauge's comment would be understood as "not every church is for all." That would never fit Adventist theology, which states explicitly that God is calling all men to become part of His remnant church. We cannot set aside our responsibility to receive new members by assuming they can go someplace else and still be part of the church. We must learn to make our church fellowship into "a place for all."

Joel Heck lists several barriers a congregation may erect that will interfere with assimilation. Heck agrees with Schaller's assertion $^{2}$ that "the capacity of a congregation to receive, welcome and assimilate new members is the second most important price tag on growth." As such, Heck places the congregational attitude "that assimilation is the responsibility of the new members" as number 1 on his list of barriers to assimilation that churches have erected to prevent new members from "spoiling things." 4 This attitude is aided by the general lack of awareness, on the part of the congregation, of the "people void" new converts feel through the loss of old friends who are not being replaced by new friends in the church. ${ }^{5}$

Heck's other barriers involve a number of items. There are considerations involving mobility of the person being assimilated. Ethnicity (although this can sometimes be a bridge as well) can bar effective entrance. The tendency toward individualism in American

${ }^{1}$ Rothauge, 18.

2 Joel D. Heck, New Member Assimilation: Practical Prevention of Back Door Loss Through Front Door Care (St. Louis, MO: Concordia, 1988), 10.

${ }^{3}$ Schaller, Assimilating New Members, 126.

${ }^{4}$ Heck, 14.

5 Ibid., 24-25. 
society builds barriers between people in general, and between persons and groups in particular, causing the group to feel the new member should "stand on his own" while the new member may likewise have negative feelings toward "joining." This would be especially the case if the prospective new member is an introvert. The tendency of any small group to reach a point of saturation is another barrier to be faced; and finally, self-centered congregations can easily put people off. ${ }^{1}$

Some barriers to assimilation come from the viewpoint of the person considering membership. Marshall Shellbey lists several possible obstacles to assimilation that might exist in a church of any size. Among them are the liturgy, unspoken behavioral expectations of the congregation, demographic of the area, location of the church (especially in urban settings where "turf" is assigned among various gang communities), and doctrinal emphasis of the church or denomination. ${ }^{2}$ Shellbey considers that the "challenge for pastoral leaders" is to decide which of these items are needed for church identity and well-being and which can be discarded to promote growth. ${ }^{3}$

\section{New Member Development}

Roy Oswald lists six stages of development new members must go through from the time they are prospects attending church for the first time to their complete commitment to the church and its goals. These stages are: Searching, when people go church shopping; Testing, when they visit for the first time to "see what it is like; Returning and affiliating, where they like what they see and affiliate with the membership to experience more; Joining, the step of formal entry into the congregation; Going deeper, as new members now seek to find their

${ }^{1}$ Ibid., 14 .

${ }^{2}$ Marshall Shellbey, "From the Editor," Leadership 11 (Fall 1990): 3.

${ }^{3}$ Ibid. 
permanent place in the congregation, both physically and spiritually; Being sent, as they enter into the service and outreach aspects of the church fellowship. ${ }^{1}$ of these, the area we are examining most closely is the "going deeper" stage.

Oswald points out that in terms of developing new members, much effort is spent on the initial four stages. But once a person actually joins the congregation, he or she tends to be forgotten. Oswald urges:

Newcomers often need further help in going deeper spiritually and finding their place through a meaningful volunteer role. Newcomers who do not successfully move through this stage often become inactive and drift to the periphery of the congregation. ${ }^{2}$

This phenomena is witnessed far too often in Adventist congregations.

Leo Schreven notes four crises many new believers face within their first two years following baptism that jeopardize their going deeper. "These years set a pattern of spiritual growth and development for the rest of the believer's life." ${ }^{3}$ First is the "crisis of discouragement." "When old habits resurface--behaviors they had renounced at their baptism--new members can become discouraged. Second comes the "crisis of integration." "The crisis of integration begins when new believers fail to replace their 'old' friends with new ones and thus do not become part of the social network of the church." ${ }^{6}$ The "crisis of lifestyle" can surface anywhere from one to one-and-a-half years following baptism. ${ }^{7}$ It is like the crisis of discouragement in that the new member feels he or she has let himself/herself down. These members have failed to integrate the value system of scripture and the

1 Oswald, 96.

${ }^{2}$ Ibid.

${ }^{3}$ Leo Schreven, "New Members and the Disappearing Act," Adventist Review, 7 October 1993, 12.

${ }^{4}$ Ibid.

${ }^{5}$ Ibid., 13.

${ }^{6}$ Ibid.

${ }^{7}$ Ibid. 
church into their lifestyle. Finally comes the "crisis of leadership." The new believers have gained enough trust among the church members to be considered for major church office. As they begin to enter into these circles, however, it becomes clear to them that the church is still a human institution, run by human beings. In Schreven's words, the church's "'halo of holiness' becomes tarnished. They recognize that all the church members are not 'saints'."2

Brad Strahan surveyed 397 Adventists from the South Queensland Conference and mentions: "The sense of togetherness and fellowship at local church level [ $\underline{\underline{s i c}]}$ is the crucial factor separating different levels of church satisfaction." ${ }^{3}$ Fellowship seems to be a key to developing this satisfaction. Schreven notes that "during the first six months, more individuals leave the church because of the crisis of discouragement or the crisis of integration than for any other single reason." People need immediate attention when in these stages ${ }^{5}$ if they are to find the friends and social placement they need to develop the sense of togetherness spoken of by strahan. "Warm, loving fellowship and deep personal relationships are significant factors in preventing apostasy," writes schreven. "In each of these crises, one major ingredient can help avert apostasy: Caring love."7

\footnotetext{
${ }^{1}$ Ibid., 14.

2 Ibid.

3 Strahan, 6-7.

${ }^{4}$ Schreven, 13.

${ }^{5}$ Ibid.

${ }^{6}$ Ibid.

${ }^{7}$ Ibid., 14.
} 
Assimilation from the New Member's Viewpoint

Certain items become visible to the church that learns to look at itself through the eyes of visitors and new members. Gary Bondurant in his article for Ministry wrote:

Contacts with the other worshipers have a greater impact [than with formal greeter or pastor]. When other worshipers introduce themselves to me, I feel more welcome, and therefore more comfortable. If they invite me to sit with them during worship, that's even better. When they offer me a smile or a hymnal or show me in some other way that I have been noticed, I am attracted by their thoughtfulness. ${ }^{1}$

Just noticing visitors is not enough, however. It is possible to notice and embarrass new people. Bondurant cautions churches to notice visitors "in appropriate ways." 2 Pasting name tags on visitors (unless the rest of the church members wear them) and asking new people to stand and introduce themselves to the worship service may have a negative effect. Friendliness and a display of genuine interest on the part of the church members are the best greetings.

When newcomers have joined the church, they expect the caring atmosphere that attracted them to continue in their lives. Ernie Voyles, the retired research coordinator for Southeastern California Conference, is quoted by Monte Sahlin as remarking: "It is a lack of love and concern that drives them out of the fellowship of the church, and the evidence of love and concern that attracts and brings them into the church!" In the same section of the book Sahlin comments that "all the surveys of and interviews with" inactive and former members show that the majority left because of negative or cool relationships with 21.

${ }^{1}$ Gary Bondurant, "Through the Eyes of a Visitor," Ministry, May 1990,

${ }^{2}$ Ibid.

${ }^{3}$ Ernie Voyles, quoted in notes by Monte Sahlin in addition to Fordyce $W$. Detamore, Seeking His Lost Sheep (Hagerstown, MD: Review and Herald, 1989), 85. 
other church members. ${ }^{1}$ Again it becomes plain: negative fellowship breeds a negative and inactive membership.

As new members approach the fellowship of the church, they will perceive one of three types of commitment they can participate in. Schaller lists them as: (1) commitment to the heritage of a particular church, (2) commitment through loyalty to the ministry and mission and contemporary goals of the church, and (3) commitment involving a little of both 1 and 2 above. He then gives this implication for assimilation into the fellowship:

The larger the proportion of members who feel a sense of commitment because of heritage ties and the smaller the proportion who are tied-in through contemporary goals, the more difficult it is to attract new members and the more likely it is that new members will soon lapse into inactivity. ${ }^{2}$

Few who have not grown up in a congregation will be able to share in its heritage. The opportunity for new members to involve themselves must therefore be found in the church's present goals. Having such goals is critical to assimilating new people into the congregation.

Synthesis

At this point it may be a good idea to try to draw together some of the thinking represented here. Most authorities in the field of small church dynamics agree that there is a difference between the dynamics of the small church and the larger congregations. Small churches, in almost every way, perceive their world in their own unique way--that of the tribe or primary group. The dimensions of time and space are truncated to fit within the lives of people--the people they have become bonded to in their church relationships. Therefore, anything that threatens the matrix in which these relationships exist is

\footnotetext{
${ }^{1}$ Ibid., 83.

${ }^{2}$ Schaller, Assimilating New Members, 79.
} 
perceived as intrusive and undesirable. The small church member's most potent defense against such disturbances is to ignore their source. If the disturbing factor happens to be a new member in the fellowship, their presence is no longer noticed or acknowledged.

This presents a challenge in assimilating new members that is not easily solved. In order for a person to truly become a part of a congregation they must become part of the central fellowship group (in small family churches) or one of the central fellowship circles (in the small pastoral congregation). These groups exhibit characteristics of the prickly pear, tough and spiny on the outside but soft and sweet once you get inside. Many candidates are turned back by the spines before they can gain admittance. Others may never become really accepted into that intimate fellowship no matter how they try.

The fact that this screening behavior is almost totally unconscious on the part of the church membership only makes it harder to deal with. This behavior must be made visible to the membership or they will deny their part in discouraging new members and place the blame on the victim. One task to which the ministry needs to address itself is that of helping the churches to see what they are really doing and why. Without confession and repentance there will be no healing.

Another area of concern is the misperception that many church administrators have concerning how small churches operate. Growth programs developed by our denomination in larger churches assume a homogeneous mind-set among all the churches, which is proactive and ready for change. Because small churches are almost totally opposite to these characteristics, church programs that seem like good ideas to church leaders raised in large church environments find little acceptance in the small church settings. Small churches are quite content to spin on from year to year, keeping to a comfortable sameness of routine, growing only enough to replace the members they lose through attrition. 
Therefore it becomes clear that if change is to happen at all, the key must be found within the people involved, not external promotions. People need time to reorient themselves, their attitudes, and desires. The road to new growth and better assimilation will be a long one and must involve a satisfactory answer to the questions of intimacy and fellowship that new membership growth apparently threatens. Based on the studies made so far, the development of cell-group structures within the larger congregation appears to be the structural answer to preserving (at least in part) the continued intimacy and fellowship small church people are accustomed to. At the same time, small cell-groups have the ability to grow and divide, reproducing themselves and providing nearly unlimited psychological space for newcomers to enter. The only thing that will be left behind is the sense of knowing all the people in the congregation and being involved in everything the congregation is doing. Even so, the separation from these things is, for many, a high price to pay for growth.

Thus the motivation for a church to change its infrastructure from one very satisfying primary group to numerous intimate cell-groups will not develop until the small congregation remembers the purpose of its existence in Jesus Christ. A theology of assimilation is needed to give the spiritual foundation for the new structures needed. It is hoped the next section of this paper will help to provide the beginnings of just such a foundation. This foundation should be especially acceptable to small churches because it is rooted in the Christian church's past experience with community: its golden age.

\section{A Theology of Assimilation}

Assimilation and the Church

The purpose of this portion of the paper is to advance a theological basis to guide in the assimilation of new members into the 
local Seventh-day Adventist congregation. New members come to us as babes needing care and feeding, acceptance and love. Yet it seems many of these "babes in Christ" are not being assimilated. This hemorrhaging through the "back door" of our churches disturbs the morale of many of our members and destroys the effectiveness of our evangelism in North America .

There are reasons why this is happening to our churches. Church members seem unaware of their responsibility on an individual and personal basis to involve themselves actively with the new members who join them.

In seeking to correct this deficiency, it is helpful to examine the scriptural evidence that relates to assimilation and church membership from two aspects: first, the aspect of God's inclusive attitude toward those who will believe in His son, Jesus; second, from the aspect of four models in the New Testament that delineate the relationship by which a new believer enters the church and functions as a part of God's plan in the church setting. These four models suggest four key words that should guide us to better assimilate new members into our church fellowships.

God's Attitude Toward Us

In the Bible we learn of a God who became personally involved with human salvation. He cared enough to prepare a place to which our rebellious race could return (John 14:2). He is the father waiting for the prodigal to return, and the shepherd braving the night to find his one lost sheep (Luke 15: 3-7; 11-32). Jesus actively accepts and strengthens all who will come to Him in time of need (John 6:37). His love was so involved that He even suffered at Calvary to redeem us from our sinful ways (Rom 5:8). He desires that all who follow Him will express that same love for one another (John 13:34-35). 
These simple facts give us a basis by which we can understand the role of our church membership with respect to the assimilation of new members. The teaching of Jesus and the Apostles indicates several models that interconnect to help us learn what assimilation is and what it involves on the part of our members and congregations.

Four Biblical Models for Assimilation

Vines, Branches, and Grafting In

The first concept comes from Rom $11: 16-24$ and John 15:1-6. Rom 11 builds the concept that the gentiles, who were not a part of Israel, have attained to the same connection, with all its privileges with God through Christ that Israel had once enjoyed. The process by which this has taken place is likened to the process of grafting. Grafting is the process in agriculture by which the limb of one plant is joined to the stem of another and allowed to grow and produce fruit. When the Jews failed to produce fruit to God and rejected the faith offered them in Christ, God had to "cut them off." Paul speaks of the grafting in of the gentile people into the stalk or vine of Israel in their place.

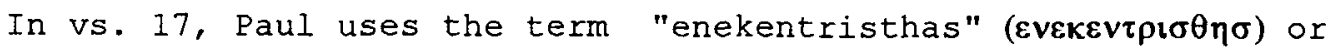
"grafting" to describe this process. This is the aorist, passive, indicative form of the verb "to graft." ${ }^{1}$ It indicates that the action of grafting is being performed on the new addition to the vine by another (in this case God) and that the grafted connection remains in the new vine from that point forward. For this to have happened, there must have been a time when the branch of the "wild olive" (gentile branch) was not a part of Israel. Now that the graft is made, however, the gentile believer shares in all "the richness of the olive tree" (vs. .

${ }^{1}$ On Line Bible Ver. 6.1, Woodside Bible Fellowship, on tine Bible USA, P. O. Box 21, Bronson, MII. (Keystroke sequence: [F5] for Strongs \#s, [F4] for definitions, Highlight \#1461 for verb definition and hit [Enter], Highlight \#5681 and [Enter] for the parsing.) 
17 RSV) just as the original branches did. There is no favoritism with God.

It is important for the local church to realize this and not to withhold any privileges or services from the new members in their midst. New and old members are both part of the same plant.

This becomes even clearer to us when we see that Jesus called Himself the "vine" and His followers the "branches" (John 15: 1-5). It is supremely important that the branch continually "abide in" Him. The

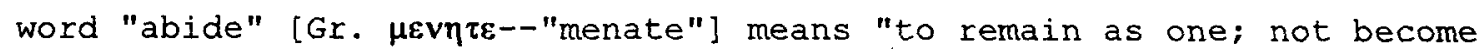
another or different." ${ }^{1}$ The implication is that once established in Christ the relationship is to continue.

"Connection" is the key word here. This first model indicates the importance of helping new members to become closely connected to Christ as the source of their spiritual nourishment. It behooves all church members, therefore, to set examples of a proper spiritual life and to encourage their new brethren and sisters in seeking the Lord. Opportunities for group prayer and study should be present to strengthen the connection of new members in the church with their Lord and Savior. Without this strong connection with Jesus our new members will not grow solid in their new faith.

The Body of Christ and Its Members

In 1 Cor 12, Paul speaks of another concept of a person's relationship to the church and Christ that has implications for new member assimilation. He calls them "members" of "the body of Christ." Paul uses the word "melos" ( $\mu \varepsilon \lambda \circ \sigma)$, which stands for "members of the human body." "Now you are the body of Christ and each one of you is a

${ }^{1}$ Ibid. (Keystroke sequence: [F5] for Strongs \#s, [F4] for definitions, Highlight \#3306 for verb definition and hit [Enter]).

${ }^{2}$ Ibid. (Keystroke sequence: [F5] for Strongs \#s, [F4] for definitions, Highlight \#3196 for word definition and hit [Enter]). 
part of it" ( 1 Cor $12: 27 \mathrm{NIV}$ ). The members are "melai ek marous" ( $\mu \varepsilon \lambda \eta \varepsilon \kappa$

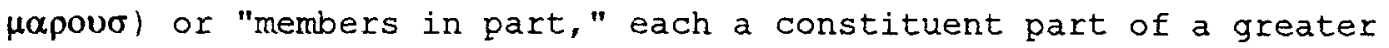
whole. Each one, then, is to be part of a team, working together to accomplish a unified purpose in Christ. This comparison shows several significant points about assimilation.

First, assimilation into the local congregation involves total integration of the talents and the gifts of each new member into the whole structure of the local congregation. New members must be invited into full involvement, according to their abilities and talents. Until they are functioning to their fullest capacity in the body of local believers, they are not assimilated into the church nor truly a part of it.

Second, assimilation into the local congregation involves discovering one's place or niche. This is determined by a person's spiritual gifts as demonstrated before the church. As the eye is placed in the head because of its gift of sight, so the new members need to be guided to their place in the church as determined by their talents and abilities. This should be a careful and planned process, following defined rules, even as the placement of the organs of the body are determined by its natural laws.

Third, from the whole passage, each gift and the member possessing that gift are to be considered supremely important to the functioning of the body. As Paul points out in vs. 22, "the parts of the body which seem to be weaker are indispensable." since the future challenges to the body of believers are unknown, the talents and abilities that God has placed in the church to meet those challenges must be guarded and trained carefully.

Finally comes an implication relating to the possible purpose of this body. The church, both local and international, into which a new 
member is integrated represents Christ in each locality. All members carry Christ's presence with them in all their daily intercourse with the community, and therefore their satisfaction and fulfillment in membership in the church is important to the spreading of the gospel. If the members of the body are sick and feeble in the eyes of the community, the church and Christ will not be attractive to them. If the members are fulfilled and happy, the community will see the power of Christ to change lives and restore hope, and their faith in the gospel will rise.

In addition to the Corinthian passage, Paul, in Rom 12, makes it clear that along with being members of the body we are also members "one of another" (vs. 5). This brings in the fellowship aspect of the gifts. True conformity to the will of Christ will involve using the gifts given for the good of the whole body of believers. Integration and assimilation into the body happen only as the member uses his or her talent within the corporate context of the church.

This is an organic view of the church in which each member lives and experiences his or her significance through the interrelationships of the whole church. The church is a living organism made up of individual parts that have been assimilated or digested into the whole. New members must be digested, processed, used, and trusted in the plans of the local church or else they will never feel a part of the organism and will be sloughed off as the roughage.

The key words for this model would be "belonging" and "purpose." The sense of belonging and purpose in human associations is one of the basic needs of the individual. We need to know that we stand in solidarity with other believers, and work together to the same ends. Without this sense of belonging, new members will certainly leave the church fellowship despite their doctrinal beliefs. It is the fellowship and the communion of believers together that strengthen the church. 
Furthermore, the church needs to assimilate new talent to survive. Since the church is the sum of its parts or members, and no two members have the same gifts to offer, the church will be a crippled body until all the gifts represented in its membership are functioning in the whole being.

Churches that reject new members or refuse to admit them into meaningful fellowship are practicing a form of starvation. They are refusing the nourishment the body of Christ needs to survive and prosper in this world. If a human does this, we call it "anorexia nervosa." People with anorexia are unable to continue to function beneficially in this world. The same is true of organizations like churches.

The Family of God and Adoption

Numerous passages in the Bible use the term "to adopt" in reference to God's plan of redemption. The term in the New Testament

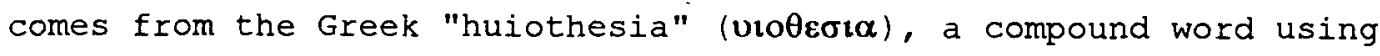
"huios" (son) and "tithemi" (to set or establish or ordain). ${ }^{1}$ Hence, in combination the word means "to set or ordain as sons." Adoption is the process of taking somebody into a family situation who was not born there.

An adopted son or daughter is entitled by that act of reception to have all the rights and privileges that pertain to the fully biological offspring. In using this term for humans, Paul is testifying to the full assimilation by grace of the gentile believers into the family of God. Now if God has extended this adoption to those who believe in Him, can the local church withhold its fellowship from the same? of course not.

The term "adoption" is used of the believer in christ in the following passages: Rom 8:15; 9:4; Gal 4:5; Eph 1:5. Each brings out

${ }^{1}$ Ibid. (Keystroke sequence: [F5] for strongs \#s, [F4] for definitions, Highlight \#5206 for word definition and hit [Enter]). 
important information for the local church. In Rom 8:15 the contrast is made between receiving the spirit of bondage or slavery and receiving the adoption. Paul makes it clear that Christians are now adopted children of the heavenly Father, and entitled to call Him "Daddy" (Gr. $\alpha \beta \beta \alpha)$. This gives them the wonderful privileges of a new family, a new relationship with God in Christ, and a new future as the Father guides His children to their eternal destinies. The word "received" in the

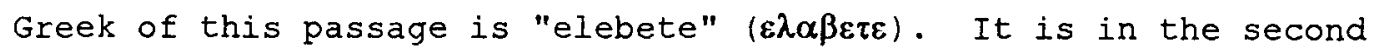
aorist, active voice and indicative mood, ${ }^{1}$ indicating that the action of adoption has been already imposed upon the believer from the throne of God. The context points to a time when this was done in the past, and the action or reality of adoption continues from that point forward with no limit. This does not speak of a "King or Queen for a day" concept, but one that is intended by God to continue, and which God enacted by His authority to be permanent.

Rom 9:4 indicates that the adoption originally belonged to the Israelites. Theirs was the "adoption," "glory," "covenants," "the giving of the law," "the worship," and "the promises." The implication in the context of Rom 8-11 is that the adoption can be lost through unbelief (9:32), for the Jews stumbled on the stumbling block, which was Christ. The gentiles, however, have gained the adoption for they have inherited the faith that Israel left behind $(9: 30)$ and have therefore been grafted into the vine and root that nourished Israel, as discussed previously. Faith is important for the adoption. It is the sole qualification.

Gal 4:5 shows that the work of Christ was to redeem humanity from the law's condemnation so that individuals could choose to receive the adoption. In this passage, the term "receive" [Gr. "apolambomen"--

${ }^{1}$ Ibid. (Keystroke sequence: [F5] for Strongs \#s, [F4] for definitions, Highlight \#5627 for parsing and hit [Enter]) 
$\alpha \pi \circ \lambda \alpha \mu \beta \omega \mu \varepsilon v]$ is in the subjunctive mode showing the conditional nature of the adoption. ${ }^{1}$ It is not certain that the people for whom Christ worked this miracle will take advantage of it, although they may do so if they choose. The word is also in the active voice and shows that the action is to be performed by the ones for whom the adoption is prepared. It is within the choice of the individual as to whether the adoption shall happen or not. Some, like many Jews, chose the bondage of law and rejected the gift of grace. But once the decision is made to receive the adoption, it will proceed as already having been accomplished, for it is the promise of God. The implication is that churches that do not receive new members wholeheartedly into their kinship circle are defying the adoption that God has chosen to give to those members, and are therefore dishonoring Christ.

In the context of Eph 1:5 we find that God thought out this adoption well in advance. Vs. 4 shows that His plans were made "before the foundation of the world." Humanity was not left to flounder in its lost condition but would be reinstated to the family of God. The word

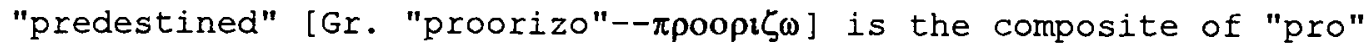
meaning "before" and "horidzo" meaning "ordained or determined." ${ }^{2}$ The RSV translates this passage: "He destined us in love to be his sons through Jesus Christ." Faith in Christ is the only qualification necessary to receive this adoption. Therefore, established church members should not impose their own restrictions and tests on new members but admit them as brothers and sisters into their personal church family as full and equal participants in the family of God. "Kinship" would be the key word in this concept. Kinship ties are some of the strongest bonds existing in any society. A person's

${ }^{1}$ Ibid. (Keystroke sequence: [F5] for Strongs \#s, [F4] for definitions, Highlight \#5632 for verb parsing and hit [Enter]).

${ }^{2}$ Ibid. (Keystroke sequence: [F5] for Strongs \#s, [F4] for definitions, Highlight \#4309 for verb definition and hit [Enter]). 
first loyalty after God is to one's family, and the church is a true family after God's plan.

Since God, the head, offers to adopt anybody who desires His Son into His family, it is imperative that the local church discover what that means and truly adopt new members and interests into its inner "kinship" circle. We need to examine the kinship ties that hold our church families together and learn to draw those who attend and choose to fellowship with us into those same relationships. In this we would be reflecting the love and grace of God to us.

We do not have a right to be individually exclusive in this matter. We cannot receive new members into our church and refuse to receive them as full family members unto ourselves. Membership into the remnant church means that each of us are family, both to God and to each other, and God expects His children to get along and help one another (John 13:34). New members who are made to feel "at home" in the family will not depart from the family, but strengthen it.

\section{The Kingdom of God and Naturalization}

The final conceptual model to consider is that of naturalization. Naturalization is that process by which a person who was politically the citizen of one country or people becomes the citizen of another. In the Gospels, Jesus went about preaching "Repent, for the kingdom of Heaven is at hand" (Matt 3:2). The word translated "kingdom" is "basilia" ( $\beta \boldsymbol{\alpha} \sigma \boldsymbol{\imath} \boldsymbol{\lambda} \varepsilon \boldsymbol{\alpha})$, which refers to the "kingdom of God" seventy-one times, and "kingdom of Heaven" thirty-two times in the Bible. From this it is clear that God has a kingdom over which He rules, and that it affects the lives of human beings.

In Eph 5:5 we read that impure and sinful people will not have a place in "the kingdom of Christ and of God." So Christ and God rule in a kingdom, and by definition that means they govern a nation. 
In the book of 1 Pet 2:9, Peter tells Christians: "You are [present tense] a chosen race, a royal priesthood, a holy nation, God's own people" (RSV). From vs. 10 it is clear that this was not always the case, for "once you were no people but now you are God's people" (RSV). In coming from the position of being "no people" and to becoming "God's people" a transformation of status took place which I liken to naturalization.

Christians are citizens of another country, even another world. They are to obey the laws of that country and honor the sovereign king of that kingdom, who is Christ and God. The present tense used in the verses above shows that even in Peter's day this status was considered to be a present reality. The adverb "now" [Gr. "noon"--vvv] indicates that this condition is "at this time" and not sometime later." This reality is available to every person who desires to take part in it, and is activated individually each time a person accepts Jesus Christ as his or her Savior and Lord.

Along with citizenship into this exalted kingdom come duties and privileges. Part of the duties are to seek to live in imitation of Jesus, advance the goals of His kingdom on earth, and keep His laws. The promises involve numerous assurances of His protection and care, eternal life, and an eternal destiny. This is all within the terms defined in the New Covenant, which state that "I [God] will be their God and they shall be my people." (Heb 8:10-11)

Assimilation into the local church involves, therefore, an acceptance of the rights, duties, and privileges of being a citizen in the kingdom of God. New members need to realize that they are now holding new citizenship papers and have entered into a superior political system. If they will accept and live in accordance with this

${ }^{1}$ Ibid. (Keystroke sequence: [F5] for Strongs \#s, [F4] for definitions, Highlight \#3568 for word definition and hit [Enter]. 
concept, they will feel the loyalty that comes with dedication to a new and better way of 1 ife and a worldwide identity with the people of God.

"Patriotism," then, would be the final key word. Patriotism has proved itself through the ages as one of those experiences that will lead people to deny their own life for the good of others. It motivated Patrick Henry to give his "one life" for his country and his people. It has motivated countless Christians through the ages to face the fire and the scaffold for the sake of their own new kingdom and Lord. The local church needs to instill this sense of history and duty into each new person who enters its gates.

The Whole Duty of the Church

The duty of the local church in assimilation of new members is therefore a fourfold task. First, it needs to facilitate each new person's connection with the vine, Jesus Christ. New members need to identify with Jesus and find their strength through a personal relationship with Him in prayer, study, and service. Next, the local church must help new believers to find their place in the Body of Christ. Experienced church members need to take these "babes in Christ" under their care and help them discover their spiritual gifts and find areas within the church structure and mission for those gifts to be exercised. Third, the local church must include new members in the kinship ties that hold the local congregation together. To do this, church members must not be aloof, keeping to their own family circles and friendship groups, but must actively invite these new members into personal relationship with themselves and their friends. Finally, the new members must be helped to identify with the kingdom of God on this earth, both locally and internationally. They need to learn the history of the church and the kingdom of God, locally and biblically, and they need to realize that they are now part of God's holy nation, sharing in 
its appointed destiny. There is comfort in knowing that God has a plan and a service for everyone who comes to Him by faith.

Once these ties are formed, the new member should be fully assimilated into the workings of the local church and the world church organizations and be ready to fulfill an active place in them. This is the point where they will become disciples and ambassadors for Christ in their workplace, family, and neighborhood relationships.

Reflection

These scriptures clearly indicate that the local church is responsible before God to promote the inclusion of each new believer within its midst. The church has been called into the world to imitate Jesus Christ. Its very existence is founded on being the present body of Christ in the world, the place in which each new believer is to find lodging. It must become the place where new believers can grow and mature before God.

For a local church to refuse to provide this spiritual and emotional lodging place is a denial of Christ. Such a church ceases to participate in the wider body of Christ and becomes none of His. The thought of rejecting anyone who presents him or herself to Christ must become anathema to any true believer, no matter what the provocation. Promotion of this responsibility among the members of small churches is our greatest argument for change and growth. They may be uncomfortable about the changes that will come to them with growth, but if they truly desire to follow Christ they will make the necessary sacrifices. The strategies already exist for them to be successful.

Current Strategies in Assimilation

There are "three broad factors that determine a newcomer's willingness to return" to a specific congregation and merge into it: 
obstacles, atmosphere, and structure. ${ }^{1}$ Obstacles include: (1) large family networks that have their own social gatherings and little energy for outsiders, (2) existing friendship groups that are similar in behavior to family networks, (3) facilities in disrepair or overcrowded, (4) unrealistic personal expectations of ministry on the part of the new member, and (5) many more. But "the greatest obstacle to newcomers' integration is the attitude of insiders." ${ }^{2}$

Many assume incorrectly that "once the new member has formally joined, the task of welcoming is complete." ${ }^{3}$ Tc assume this leads many churches to neglect the needs of their new members. The local church is responsible to help new members become active parts of its fellowship, and is therefore the primary culprit when new members become inactive. ${ }^{4}$ Therefore the small church will need to develop its ability to welcome and involve new people.

In order to do this, small churches need to cultivate "a positive self-image." ${ }^{5}$ A church with a negative self-image will not have the energy to incorporate new people into its midst and will not be attractive to new people, who will sense the listlessness or combative elements in its makeup. ${ }^{6}$ strategies for incorporating new members into small congregations will therefore need to work on these two areas, or else the church will draw in upon itself to conserve energy. The resulting cliquishness will destroy any attractiveness the church membership may have had before the community. Churches will also become

\footnotetext{
${ }^{1}$ Calvin C. Ratz, "The Velcro Church," Leadership 11 (Fall 1990): 38, 39.

${ }^{2}$ Ibid., 39, 41.

${ }^{3}$ Bast, 135.

${ }^{4}$ Ibid., 136.

${ }^{5}$ Savage, 31.

${ }^{6}$ Ibid., 31, 32.
} 
closed to change, and growth is change. "A negative self image is a terminal illness in many small churches."i

"The self-image a church has is often determined by the kind and quality of ministerial leadership."2 Increasing a church's ability to assimilate new people involves building up the church's view of itself. Here are four methods by which pastors may build their church community.

The pastor is to promote experiences that will help build a sense of community and togetherness. . . The pastor must help the congregation feel proud of its identity as a parish. . . . Visibility of the pastor in the community is necessary. . . The pastor might promote small groups in the parish. ${ }^{3}$

One of the best ways a pastor can help build up his church is by bringing in new members and helping them to integrate into the fellowship. This is a necessary first step to building the church's ability to assimilate new people, but it is slow. Pastors can handle only six to ten new people at a time." Since it takes months, and even years, to work a new person solidly into a fellowship, this severely limits the number of persons a pastor can guide in.

Many churches seem to function solely with the pastoral model for assimilation. Members assume that newcomers are totally the pastor's business and do not become involved without an invitation.

This is not only a bottleneck to the process of growth in a congregation but often leaves the newcomer feeling frozen out of the fellowship.

Therefore, pastors should seek to involve the church as soon as possible in the assimilation process so that the membership will function appropriately toward new believers.

${ }^{1}$ Ray, 37.

2 Ibid. 38.

${ }^{3}$ Father David O'Connor, "Rural Pastoral Leadership I: The Pastor," in Ministry in the Small Church, ed. David G. Andrews (Kansas City, MO: Sheed and Ward, 1988), 94.

\footnotetext{
${ }^{4}$ Rothaugh, 17.
} 
One of the first things the pastor should initiate is a spiritual guardianship program. At the baptism of the new member, an established church member should be chosen to engage in a "Barnabas Ministry," taking the new believer under his or her care and guiding him or her carefully into church fellowship. Spiritual guardianship programs work under the process of "adoption," ${ }^{1}$ as defined earlier in this paper. Therefore, they can be especially effective in very small churches where there are few groups into which new believers can integrate. The spiritual guardian should invite the newcomer into his or her own fellowship circle, introduce him/her to others, and be his/her best friend in the congregation until he/she can become comfortable with the entire membership. Some have expressed disappointment in the spiritual guardian program of late because it seems to have lacked effectiveness, but if the person chosen to shepherd the new member is carefully selected (he or she should be a "Barnabas," "son of encouragement") and trained, the program could bear much fruit. (see appendix D for information and suggestions).

Another thing the pastor should involve his church members in is visitation. Visitation by church members to the homes of new believers can accomplish several important things. First, it helps the new member to become acquainted with the visiting member and to feel accepted. Second, and as important, the new members may have questions concerning the congregation and its norms that require an answer from those "in the know." Newcomers will need to learn about the history of the congregation, its traditions, who its leaders are, and bond with them personally. ${ }^{2}$ Another important aspect of visitation, at least in SDA circles, should be to help new believers deepen in their new faith.

Men of the best ability should be chosen to help in the effort. They should enter heartily into the work of visiting and holding

${ }^{1}$ Sells and Crandall, 14-15.

${ }^{2}$ Bast, 126-128. 
Bible readings with those newly come to the faith, . . endeavoring to establish them in the faith. The new believers are to be carefully instructed, that they may have an intelligent knowledge of the various lines of work committed to the church of Christ. ${ }^{1}$

Another list of the benefits of visitation is:

Regular visitation by elected leaders and the pastor (1) keeps communication lines open, (2) stimulates regular attendance, (3) strengthens motivation to return tithes and offerings and (4) keeps discouraged members from leaving the church. ${ }^{2}$

In addition to visitation, the pastor should encourage members to involve newcomers in their own responsibilities in the church. There are two assumptions helpful to doing this properly. These are: "(1) God has entrusted to each believer the necessary resources to do what he has called that person to, and (2) God has given each church the people necessary to do what he has called the church to do." ${ }^{3}$ The local church should help them to identify their spiritual gifts, and then help them to discover where their gifts will fit in the congregation's ministry. ${ }^{4}$

The key to establishing this valuable pool of laborers was the church's ability to help people realize the practical meaning of the New Testament teaching about servanthood, and the responsibilities we have as followers of Christ. . . That ministry is a give and take proposition. ${ }^{5}$

"Everyone should feel that he is responsible to God for all the talent he has given him, and that he should use these entrusted talents to God's glory." 6

${ }^{1}$ Ellen G. White, "Notes of Travel--No. 5 Los Angeles, Cal.," Advent Review and Sabbath Herald, 2 March 1905, 8.

${ }^{2}$ Thomas A. Stafford, "Tacoma Central Seventh-day Adventist Church: The Interdependent Ministry of the Pastor and Head Elder" (D.Min. Project Dissertation, Fuller Theological Seminary, January 1985), 119.

${ }^{3}$ Ron Oertli, "Finding the Fit," Leadership 11 (Fall 1990): 130.

'Barna, 163.

${ }^{5}$ Ibid., 162 .

${ }^{6}$ Ellen G. White, "Serving God Fervently," Advent Review and Sabbath Herald, 26 July 1887, 465. 
Finding the area for involvement for a new believer develops "those all important relationships that help people feel at home" in the church and helps one to "mature spiritually."1

The best help that ministers can give the members or our churches is not sermonizing, but planning work for them. . . Especially should those who are newly come to the faith be educated to become laborers together with God. ${ }^{2}$

When the church has developed to the point of forming multiple cells or groups, it can move from methods of adoption to addition. "Growth by addition is adding service and program units to meet needs, or starting new groups for fellowship and service." ${ }^{3}$ One of the most effective methods of addition, in any congregation that will receive it, is the formation of cell groups.

Cell groups take the larger family of the congregation and break those willing to participate into intimate subfellowships where new members can form immediate and meaningful friendships with other members. Carl George writes: "With each new wave of technological advancements, people seek a compensatory human touch. . . I believe that opportunities for interpersonal exchange, such as small caring groups, are needed more than ever." "Healthy small groups combine evangelism, spiritual nurture, and calling to service." 5

Authorities suggest that any congregation that has more than forty adults attending should form into small cell groups. ${ }^{6}$ One reason for this is that few humans can handle more than ten intense

${ }^{1}$ Warren Bird and Michelle C. Bird, "When Should Newcomers Become Leaders?" Leadership 11 (Eall 1990): 123.

${ }^{2}$ Ellen G. White, Testimonies to the Church, 9 vols. (Mountain View, CA: Pacific Press, 1900), 6:49, 50.

${ }^{3}$ Sells and Crandall, 15.

${ }^{4}$ George, 15.

${ }^{5}$ Ibid., 59.

${ }^{6}$ Nelson Annan, More People: Is Church Growth Worth It? (Wheaton, IL: Harold Shaw Publishers, 1987), 40. 
relationships at one time. Cell groups keep people the primary focus. ${ }^{1}$ They also provide "doors," "multi-entry points" into the inner fellowship of the church where a newcomer may be able "to find people with similar interest and values, to participate in satisfying activities, and to build new relationships." 2

Thomas Stafford, pastor of the Tacoma Central Seventh-day Adventist Church in Washington, believes that the number of inactive members there "would be greatly reduced if we had elders and other leaders being responsible to gather groups of members or non-members for prayer, study or other kinds of fellowship." ${ }^{3}$ This is undoubtedly true; however, there is a resistance in many SDA churches toward the intimacy of small groups. ${ }^{4}$ They are leery of the closeness that develops in small group settings and resist those who would establish cell groups.

The effectiveness of small cell groups for evangelization and assimilation of new members is established by a study conducted in the Presbyterian church. Several pastors were encouraged to develop "cell" groups in homes. When they had a sufficient number of these "cells" meeting regularly, the pastor was to pull them together and integrate them into a new church. There were two results: (1) some cells integrated into one "big happy family" and became one primary group incapable of growth, and (2) some cells did not integrate, but retained their own identities while worshipping together with other cells. These churches continued growth. They had never developed the expectation of having to know everybody else. ${ }^{5}$

\footnotetext{
${ }^{1}$ Maner, 32.

${ }^{2}$ Rothauge, 18.

${ }^{3}$ Stafford, 119 .

${ }^{4}$ Martin, 1.

${ }^{5}$ Dudley, Unique Dynamics, 14.
} 
Small cell-group intimacy can become so intense that non-members attending small cells in a church will often request membership in the church because they feel so at home with their newfound friends. ${ }^{1}$

of course, there are always people who just wish to be left alone. Calvin Ratz suggests that "they may lack a basic commitment to God, and no amount of friendliness will make them stay. Others bear the imprint of our culture that recoils from commitment to anything." Perhaps the best council regarding these people is not to try to integrate them at all. They may be more comfortable if allowed to grow silently in the midst of the congregation.

\footnotetext{
${ }^{1}$ Dudley, Where Have All our People Gone? 76.

${ }^{2}$ Ratz, 45.
} 


\section{CHAPTER 3}

\section{A DESIGN FOR INCREASING THE AWARENESS OF NEED FOR ASSIMILATION AMONG SMALL-CHURCH MEMBERS}

"Every congregation has unwritten rules about who is welcome in its midst." Most congregations are unaware of this "screening behavior" and the norms upon which it is based. Therefore these conditions become a sort of autopilot, functioning to exclude or include new members without the congregation's conscious involvement. It is, therefore, necessary to help the congregation to see what it is doing that pushes new members away and to encourage them to become more inclusive.

The best way to accomplish this is not to point out continually what they are doing wrong with respect to nurturing new members, but to continually hold up before them the vision of how to do it right. Pastors may include this theme often in their sermons on Sabbath morning and in their teaching at prayer meeting. Elders' and deacons' meetings may be called to educate the leadership of the church concerning the needs of new members. Above all, the individual member needs to gain a vision of his or her place in helping the new people in their midst to feel welcome, wanted, and at home.

At these user friendly churches members realize that inviting people to church was only part of their responsibility. . . . They also were responsible for accompanying the guest to the church activity, as well as for following up with them. It was not the task of a "visitation team" or an "evangelism team" to make the visitor feel welcome. The strategy called for the person who did the inviting to also provide on-site hospitality and post-visit debriefing.

\footnotetext{
1 Oswald, 49.

2 Barna, 100.
} 
Barna considers assimilation to begin with the first visit of a prospective new member to the church services. The counsel he gives naturally applies also to the new member when he or she has joined the fellowship.

This is the thrust of the comments of Doug Murren in his audio tape, Assimilating Newcomers into Ministries. Murren pastors the Eastside Foursquare Church in Kirkland, Washington. Speaking of pastors he says: "We can't assimilate people anymore."1 "Assimilation is the assignment of the entire church. It must be incorporated into the very philosophy and fiber and self identity of the church." ${ }^{2}$ Murren believes each church member is responsible for including those persons he or she brings to the services. Members should stay with them through the process of assimilation until they too are involved in ministry. ${ }^{3}$

From the church member's initial point of view, however, assimilation also requires something of the new church members. John Savage writes:

Consider the people who join a church. Although these people likely are coming because of their own anxieties, the church expects them to make new friends, accept unfamiliar beliefs and practices, learn new social rules, and become active in the congregation. ${ }^{4}$

This list of tasks may be in the back of the minds of the established members, but it may not be what motivates the new believer.

But newcomers are troubled. . . They're coming to church in hope of finding friends. They want help, not new assignments. Consequently, the church that wants to incorporate these people will have to do most of the giving, bending, and reaching out. ${ }^{5}$

${ }^{1}$ Doug Murren, Skills for Ministry Leaders: Assimilating Newcomers into Ministry (Pasadena, CA: Charles I. Fuller Institute, 1994), Audio Cassette in the Pastor's Update Series, Vol. 55.

${ }^{2}$ Ibid.

${ }^{3}$ Ibid.

${ }^{4}$ Savage, The Teflon Church, 31.

${ }^{5}$ Ibid. 
Many church members have not realized their duty in this regard. As one writer put it, "Newcomers don't come with Velcro already applied. It's up to the congregation to make them stick." ${ }^{1}$ And as another asserts: "People come back to a church where they feel welcomed, valued, and needed." 2 "Friendliness and warmth of the church" is a big part of helping newcomers return. ${ }^{3}$

\section{A Theoretical Model for Building Awareness of the Church's Need to Assimilate New People}

In preparation for a theoretical model in promoting assimilation in small churches, it is helpful to introduce a few new terms into the vocabulary of this paper:

Latitude of acceptance: "The range of positions on an issue that the individual finds acceptable to him."

Latitude of rejection: "The positions he finds objectionable."5

Reference scale: An established set of reference points, either internal or external to the individual, "composed of categories of acceptance and rejection" by which he or she judges the characteristics of various stimuli. ${ }^{6}$ Reference scales may be psychosocial in nature.

Scales for categorizing stands on religious, moral, and social issues, which are more resistant to change, are psycho-social scales and are formed relative to stimuli which are not objectively well-graded. . . . They become the regulating basis for the individual's evaluations of his relations with people, issues, and prevailing social practices. ${ }^{7}$

\footnotetext{
${ }^{1}$ Ratz, 38.

${ }^{2}$ Bast, 89.

3 Ibid., 61.
}

${ }^{4}$ Muzafer Sherif and Carl I. Hovland, Social Judgment, Assimilation and Contrast Effects in Communication and Attitude Change (Westport, CT: Greenwood Press, 1961), 129.

${ }^{5}$ Ibid.

${ }^{6}$ Ibid., 182, 183.

7 Ibid., 37. 
Learning: "The conditions and extent of past experience with the stimulus material" that influences "the nature of an individual's judgment scale and his placements of relevant stimuli."

Ego involvement: The degree of a person's personal involvement with a subject. ${ }^{2}$

Threshold of acceptance: Related to "latitude of acceptance" and refers to the degree of difficulty an individual experiences with respect to the acceptance of an idea, position, or situation. In experiments with individuals exhibiting high ego involvement, it was noticed that they rejected more items than they accepted. The conclusion was therefore reached that "high ego-involvement with an issue produces a raised threshold of acceptance of positions on the issue, a relationship which results in an extensive latitude of rejection." ${ }^{3}$

Anchorages: Stimulus factors external or internal to the individual, "concepts or categories previously formed by the individual during the course of encounters with the stimulus in question."4 Assimilation effect: "An anchor located near the limits of a psychological scale produces an assimilation effect: Judgments are shifted in the direction of the anchor."

Assimilation range: That range of stimuli near the limits of a psychological scale in which an assimilation effect may occur. ${ }^{6}$

Contrast range: That range of stimuli too far removed from the limits of a psychological scale for assimilation to occur.

\footnotetext{
${ }^{1}$ Ibid., 183.

${ }^{2}$ Ibid., 129.

${ }^{3}$ Ibid., 130.

${ }^{4}$ Ibid., 30.

${ }^{5}$ Ibid., 182.

${ }^{6}$ Ibid. , 49.
} 
Contrast effect: When an anchor located in the contrast range of an individual is rejected as being far removed from the individual's position. ${ }^{1}$

It has been noticed in experimentation that a people will respond to a position relatively close to his or her own thoughts and ideas by considering it as being much closer to his or her position than it really is. ${ }^{2}$ This assimilation effect can help promote change.

In theory, a person may be led to change by a series of wellplaced stimuli (anchors), just to the limit of what the individual or group of individuals finds acceptable, thus producing an assimilation effect. The new position is accepted into the individual or group's psychosocial scale of reference, and that scale of reference will thus be displaced in the direction of the new idea or position.

A possibility for promoting change through communication might be that of stating a position which differs so slightly from the individual's own position that it falls at the limits of his latitude of acceptance or perhaps within a noncommittal area between the latitudes of acceptance and rejection. These circumstances are conducive to an assimilation rather than a contrast effect. . . The communication is assimilated and placed closer to the individual's position than it is in fact. - . Conceivably, in such small doses, the holder of an intense position might be gradually shifted. ${ }^{3}$

Figure 2 below illustrates how this can be worked out. The downward pointing arrows represent anchors or positions presented to a person with a defined reference scale. The reference scale itself is relatively narrow and represents the positions he or she has taken with respect to a subject based upon personal and hearsay experience. There is a range of positions beyond the individual's present range of consideration, however, which they would accept as being like their own (whether or not this is in fact true). This is the assimilation range.

\footnotetext{
1 Ibid., 181.

2 Ibid. 188.

${ }^{3}$ Ibid. , 195.
} 
Positions or anchors " $a, b$ " and " $j, k$ " fall well outside of this assimilation range and would probably be rejected. Positions "e, " $f$," and "g" fall well within the range of current opinion and therefore would serve only to reinforce the individual's already-held reference scale. Positions " $d$ " and " $h$ " however have the potential to change opinion, for they are somewhat diverse from what has been already accepted about the subject but not so diverse as to be rejected. The assimilation effect will therefore incorporate either of these into the already-held reference scale. But what about positions "c" or "i" with respect to assimilation? According to this chart they would be rejected, but they would also probably introduce some dissonance into the thinking of the individual, who might then be moved by persuasion. Either rejection or acceptance could be difficult for them.

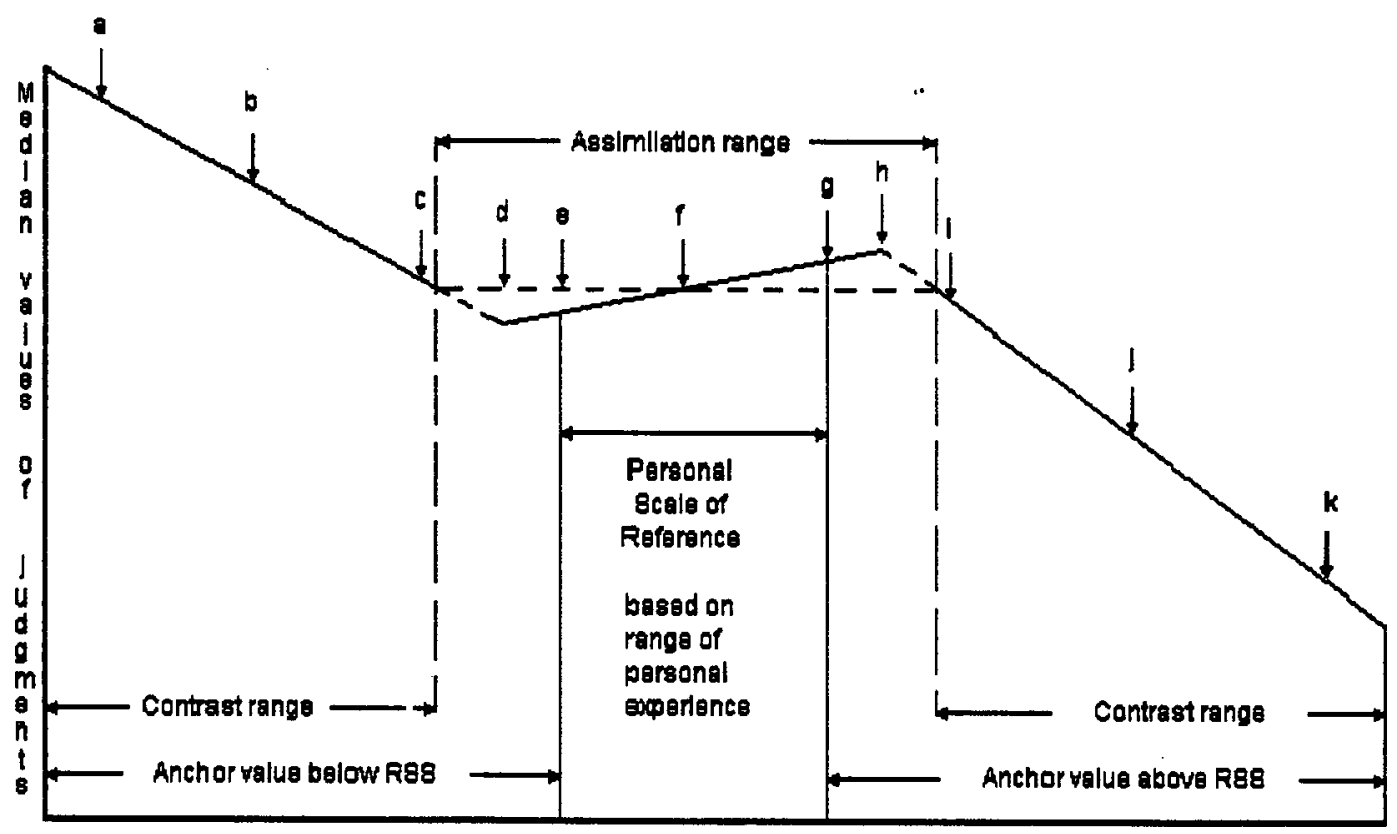

Pig. 2. Scale of judgrwents upon a continuum involving assimilation range and the contrast ranges relative to a person's personal reference scale. This chart is a noditicacion of a chart given in: Huzafer sherif and Carl $I$. Hovland, Social Judoment: Assimilation and Contrast Effects in Conmunication and Attitude Change (Testport, CT: Greenwood Press, 1961), 49. 
The key to change would be to keep presenting positions like "d" or " $h$ " to the individual, and giving them time to digest the new information and make it part of their new reference scale. The reference scale would then shift slightly to include the new material. When this shift is complete, another position in the same direction on their now modified reference area will result in further change in attitude and behavior.

Here we see the importance of consistent preaching and upholding the true positions of the gospel before our churches. People come into the church after a long process of ridding themselves of the reference systems of the world and being exposed to the reference scales of heaven. At first they are not able to accept all that heaven has to offer them, for their reference systems are contaminated with the thoughts and values of the secular world around them. However, as they are exposed over and over again to the truths of the gospel they find more and more that gradually falls within their range of assimilation, and as they accept and believe these new positions they are changed. As the apostle Paul wrote in 2 Cor 3:18: "But we all, with unveiled face, beholding as in a mirror the glory of the Lord, are being transformed into the same image"1 (NKJV).

When small-church groups reject people who come among then, it is often because something in those people falls outside of the range of their accepted values. By continually holding before the people the vision of Jesus and His inclusion of all people into His ministry, the preacher may influence change. By sermon and personal labor, he or she can begin to sensitize the church membership to their duty before God to imitate Christ in His healing ministry and make room in their fellowships for those who will come in to join them.

${ }^{1}$ The Open Bible, expanded ed. (Nashville, Camden \& New York: Thomas Nelson Publishers, 1980), 1177. 
But the process is slow and arduous, and there is great frustration when the established value systems of the membership conflict with the values of the preacher. Research shows that when a person holds strong opinions, change is resisted strenuously. ${ }^{1}$ His or her tendency is to see issues as "black or white." ${ }^{2}$ Furthermore, the value scale of the group in which the individual is a member, or aspires to be a member, will influence his or her judgments of a stimuli. ${ }^{3}$ Therefore, the minister seeking to influence his membership to become more inclusive to newcomers is faced with shifting the reference scale of the entire congregation as a whole.

Kembleton Wiggins, in his book Soul Winning Made Easy, points out that behavior is influenced by three major areas of concern on the part of the person we are trying to move. Although his book deals primarily with moving evangelistic audiences in meetings to modify their behavior in harmony with the messages given, the same principle can apply for any desired behavior change. These three areas are: the person's attitude toward a certain course of action, the person's beliefs about the expectations of other people around them, and the person's motivation to live up to those expectations." The congregation's likelihood of modifying its behavior to fit the message of inclusiveness toward newcomers among them will be most likely achieved, therefore, if these three aspects of motivation are kept in focus.

The minister will need to help the congregation see their need for change as a whole and build the desired attitude toward the act of inclusion and assimilation. "This involves beliefs about the

${ }^{1}$ Sherif and Hovland, 129, 130.

'Ibid., 187

${ }^{3}$ Ibid., 125.

${ }^{4}$ Kembleton S. Wiggins, Soul Winning Made Easy (Mountain View, CA: Pacific Press, 1975), 14,15. 
consequence of performing the act and [each member's] personal evaluation of those consequences." ${ }^{1}$ The blessings of an inclusive fellowship therefore need to be presented to offset the apprehensions the church member may feel at becoming a larger, less intimate group.

The presentation must also address what the membership is thinking about the expectations of their fellow members, with whom they have probably formed strong bonds over the years. "If an influential person in [their] life expects [them] to decide against your suggested action, [they] will either make an unfavorable decision or a weak favorable one." ${ }^{2}$ The important thing to get across to the church is that Jesus expects them to draw in people from the world and to grow and increase, and to do this a church must be inclusive. ${ }^{3}$ Numerous passages in the Bible make this clear: "Go therefore and make disciples of all the nations" (Matt 28:19a, NKJV); "But you shall receive power when the Holy Spirit has come upon you; and you shall be witnesses to Me" (Acts 1:8a, NKJV); "Freely you have received, freely give" (Matt 10:8b, NKJV). The example of the early church members--growing and including new people as fast as possible--is an indication of what the Lord is leading Seventh-day Adventist church members to be like in the last days. Furthermore, the call to be the three angels' messengers, going to all the world to prepare for Jesus' soon return, indicates a work for the Lord that no Adventist church can ignore except at its own peril. So Jesus' stand concerning the actions that will result in assimilation of new members into the church is firmly on record and motivates inclusion. The remaining item that needs to be covered with the congregations, over and over, is that of their motivation to live up to

\footnotetext{
${ }^{1}$ Ibid., 15, 16.

${ }^{2}$ Ibid., 16.

${ }^{3}$ Ibid.
} 
what Jesus expects of them. ${ }^{1}$ This may seem to be a given, but it should not be taken for granted that whatever Jesus expects of us we will collectively desire to do. The truth is somewhere else. Church members need to grow in their relationship with Christ before they will allow Him full access to their lives. The grace of God in calling them out of the world and to life; the sacrifice of His life on Calvary so that they can live in newness of life for all eternity--these themes need to be a constant thread in every sermon. The purpose here is to help their love for Christ to grow for, as Jesus said, "If you love Me, you will keep My commandments" (John 14:15 margin, NASV).

\section{The Construction of a Technique for Bringing This Awareness to the Local Congregation and Leading Them to a New Vision of Their Role in Receiving New Members into Fellowship}

In seeking to help the local congregation develop an awareness of the need for, and begin to find a vision for, assimilation of new members, I relied upon two things already mentioned. The first is the constant repetition of the need for assimilation as a theme in sermons and presentations. The second is the development of a seminar to sensitize the church member to his or her roll as an assimilator. Since the sermon requires that the pastor of the church be involved in this project over a period of time that transcends the limits allowed for this project, the seminar approach was the method chosen. It, alone, could potentially produce some results over a short time frame.

It was decided that the seminar should be centered in an attempt to help the church evaluate how it has received new members over time. A questionnaire was developed to allow the church members to respond to various stimulus statements relating to their attitudes and behavior with respect to new members and their expectations and perceptions

\footnotetext{
${ }^{1}$ Ibid., 17.
} 
regarding who is responsible for them. The questionnaire was given to the church members at least one month in advance of the prospective seminar to allow time for analysis of the data collected and the tailoring of the presentation in the seminar to the needs of the local church body. In addition to the questionnaire, a survey of ten small churches in the area, including the subject church, was conducted to gain hard data on how the local congregation was doing in retention of its new members in comparison to the community of churches in the region. During the seminar, this information would be given back to the local congregation to help their self-evaluation.

Before the seminar, and as a preparation for it, a sermon was given. The sermon presented the biblical injunction to receive new people into our fellowships and to help them become part of the active church. The sermon was given during the Sabbath worship service at the church, and was followed that afternoon by the seminar.

It was recognized that members may need to be jolted into understanding something of what new members among them might be experiencing. The inclusion of a group exercise to help members experience the feelings caused by screening behavior was therefore thought necessary, along with discussion on how the experience affected them. ${ }^{1}$ Members were to go through this structured exercise to expose the unconscious screening behaviors that often deter newcomers, then they were given time to digest the experience and compare it to behaviors they had already seen in church life.

The seminar was conducted primarily in a lecture-response format in which the participants were encouraged to take in information, then respond to it, both in group discussion among themselves and in feedback sessions with the facilitator-lecturer. It was felt that, although this

${ }^{1}$ The experience used here was borrowed from the Lab 1 training seminars conducted by John Savage: Savage, Mitchel, and Nelson, Lab I Leader's Guide, 6. 
approach would not be able to impart as much information to the church for the time spent in the seminar, it would see that the essential information was digested and made useful in the most efficient manner possible. This is especially important since the seminar was aimed, not only at imparting information, but at helping the group to assimilate and use that knowledge in promoting change.

Lectures used in the seminar were either borrowed or constructed from materials given by a variety of authors. Information was chosen on the basis of whether it would be helpful in aiding the church members to understand themselves, as an organization, and the experience others might have in joining them. The lectures included a section on why people remain in active membership (borrowed from the Lab I Leader's Guide), ${ }^{1}$ and a section on church structure: the sand-dollar effect for larger small churches (taken from Carl F. George's book, Prepare Your Church for the Future) $)^{2}$ and the family church structure for very small churches (taken from Arlin J. Rothauge's booklet, Sizing Up a Congregation).$^{3}$ One further lecture on assimilation compares the method of adoption with that of cell-group formation and proposes a structure for the church that would vastly improve its ability to assimilate new members if implemented (also taken from Carl George's book). ${ }^{4}$

After the seminar, the original questionnaire (somewhat modified) was given to see if there was any change in the types of responses returned by the members of the church. This would be taken as an indicator of whether the seminar had any effect on the membership and its thinking. See appendix $C$ for seminar materials.

\footnotetext{
'Ibid., 60-62.

2 George, 64-66.

${ }^{3}$ Rothauge, 7-13.

'George, 85-106, 158.
} 


\section{CHAPTER 4}

\section{IMPLEMENTING THE PROCESS}

As stated earlier in this paper, this project was an attempt to increase the awareness of local church members to the needs of newcomers. The proposed process for this was through the development of a short, Sabbath afternoon seminar using interactive techniques and lecture information gained from surveys performed in the local church setting. It was hoped that the church members would show an interest in learning what the needs of new members are, and how to help these newborn members become an integrated part of the local congregation.

The effectiveness of this approach was to be measured by the responses given by church members to a forty-question survey, given one month before the seminar, compared to another nearly identical survey to be given to seminar participants after the seminar was completed. The relative scores shown in the two surveys were to give an indication of any changes that might come as a result of the seminar approach.

\section{Choosing the Churches}

The churches chosen for the experience were three small to very small congregations in central Pennsylvania. The smallest church and the largest church were part of the researcher's district, while another small church was chosen from a neighboring district. Churches were chosen on the basis of their size (between 15 and 100 members in worship attendance), and some consideration was given to past performance in assimilation. None of the churches chosen had held members well over the years. The assimilation rate of one of them was zero, and another 
was assimilating only about a fifth of those who had come to its doors.

The remaining church had just below an average number of successful assimilation to its record.

It was desired to represent both the small and very small membership church in the study. The dynamics of each is somewhat different and therefore the methods of assimilation used by each one differ. Whereas methods of adoption would prevail in the very small membership church where all members must become integrated into the single family-style core, the small membership church will have several groups functioning among which a new member may choose. Inclusion into one of these groups, however, is as necessary in the small church as in the very small membership church.

Each church was contacted with the opportunity to participate in the study and subsequent questionnaire. The invitation was carried by the pastor to the church board for approval. The three churches that approved of holding the seminar were then scheduled for the holding of the program on a Sabbath afternoon.

The Seminar and Questionnaire on Assimilation The seminar was based, in part, on prior results as seen from the questionnaire. The questionnaire consisted of forty questions dealing with a person's attitude toward the mission of the church and new members in particular. Members were asked to rate themselves through a behavior scale of one to five on how they had related to new members in the past. Behavioral rather than conceptually centered questions were felt to be the most likely to show the true attitudes of church members. Many may think they are open to those outside the walls of the congregation, but show little behavioral interest in them. Therefore, while concept items were included, the real weight of the evaluation instrument was upon behavior. 
This information was studied during the month prior to the seminar and a report was prepared from it to feed back to the church the results of the survey, with an emphasis on some of the church-growth and assimilation attitudes it reflected. The first third of the seminar was occupied in this manner, using lecture and feedback with the entire group of participants. Church members were told that this information was just the picture they had presented of themselves. If they did not like the picture they could take steps to change it. If they liked the picture they were acquainted with some of the possible results with respect to new member assimilation. The survey and accompanying results appear in the appendix B to this project report.

The seminar actually began during the Sabbath morning preaching service as I gave the sermon "Doors into the Church." The sermon was to give a spiritual foundation for the seminar to come, helping the participants to look at assimilation from the viewpoint of the Bible and God's will for them. The seminar then progressed, after a fellowship meal, with group building and the survey results. The group then broke up into smaller groups to discuss the findings of the survey and any feelings they developed during the presentation. Each group then shared its results with the larger group.

This phase of the seminar was followed by an exercise to help the participant experience, consciously, the screening process often employed unconsciously by church members to exclude, or screen, newcomers. This exercise and its sources have already been dealt with in chapter 3. It produced significant insights among the participants concerning the screening process.

The screening experience and its discussion period was then followed by another lecture taken from the Lab I materials dealing with what holds people in the church. ${ }^{1}$ In this lecture, Savage points out

\footnotetext{
${ }^{1}$ Ibid., 60-62.
} 
that the things that keep most active members active are their faith, their friends in the church, and the groups they belong to. When faith begins to break down, the person's friendships and their group involvement keep the member steady as he or she struggles to find new faith in the Lord and His work. Participants were then given an exercise in which they wrote down (or in one case, expressed verbally) why they were still active church members in the Seventh-day Adventist church.

Two short lectures followed this exercise, presenting the various structures that small churches usually exhibit. The very small church structure was that of the primary cell with matriarch and patriarch and gatekeeper. Much of the material for this lecture came from Arlin Rothauge's booklet, Sizing up a congregation for New Member Ministry, with an overhead chart taken from page $7 .^{1}$ The material for a fifty- to one-hundred-member small church structure was taken from carl George's book, Prepare Your Church for the Future, using an overhead slide from page $65 .^{2}$ In each of these lectures, the appropriate means of assimilation used by such churches were presented.

One final lecture was given before closing the seminar. It was titled, "What Is Needed? A Place for New People." It is a short presentation suggesting that the local church consider moving from the congregational structures presented into a new, small cell-group structure implementing what Carl George calls the Meta Church. Material here is taken from Carl George's book, Prepare Your Church for the Future, ${ }^{3}$ and a related quote from Testimonies to the Church, vol. 7, by Ellen G. White." The thrust of this material is to encourage the church

\footnotetext{
${ }^{1}$ Rothauge, 7-13.

2 George, 64-67.

${ }^{3}$ Ibid., 87-92, 158.

${ }^{4}$ White, Testimonies to the Church, $7: 21$.
} 
to develop small cell-group structures into which they may invite new members, and which they might join or even start. This would allow much faster and better assimilation of new members than the adoption method so often relied upon. This lecture was followed again by group discussion. The revised questionnaire was then passed out and filled in by the participants to see if the presentations had any effect upon their thinking with respect to new members and their needs.

\section{Results of Implementation of the Seminar}

The seminars held in the three churches showed some effect, overall. However, due to an observation to be dealt with further in the evaluation section, the results are questionable. The readouts from analyzing the data collected can be found in the appendix $B$ to this paper. Only the most pertinent responses are covered here.

The Initial Questionnaire and Its Results

The questionnaire was divided into seven areas of inquiry: personal demographics, personal experience with the local church, personal view of the church's mission, personal commitment to the church's mission, personal attitudes toward assimilation of new members, personal behavior toward new members, and personal evaluation of the church's performance toward new members. From these it was hoped insights would be gained concerning the local church and its prospects for assimilation.

Membership Demographics

The demographic questions began the questionnaire. They dealt with length of time the members had been a part of the local church (question 1), age range (question 2), reason for attending (question 3), and whether or not they hold current office positions in the church (question 15). Of these four, question 1 on the length of time the 
members have been in the local church fellowship has some of the greatest light to shed on assimilation potential. Lyle schaller wrote that when the median tenure of members in a congregation has been ten years or longer, that local church has had difficulty in assimilating new people. ${ }^{1}$ In the three churches questioned, those who had been members for over ten years all composed more than 50 percent of the membership. The range was from 54 percent in one church to about 64 percent in another. This indicates that these three churches need help in gaining and holding new members.

The age ranges of the membership would also be influential with respect to the church's ability to attract new people. Table 9 shows the distribution of age in each of the congregations.

Table 9.--The distribution of age in the church congregations surveyed by percentage of those tested

\begin{tabular}{|l|c|c|c|}
\hline Years of Age & Church 1 & Church 2 & Church 3 \\
\hline Less than 20 yrs. & 5.68 & 0.08 & 2.48 \\
\hline 20 to 30 yrs. & 5.68 & 10.78 & $19.5 \frac{8}{8}$ \\
\hline 31 to 50 yrs. & 27.88 & 32.18 & 36.68 \\
\hline 51 to 65 yrs. & 33.38 & 28.68 & 31.78 \\
\hline Over 65 yrs. & 27.88 & 28.68 & 9.88 \\
\hline
\end{tabular}

As can be seen from the table, most of the churches have very large numbers of their people in the above fifty range. Interestingly enough, the assimilation rates for these churches on the ten church survey showed a possible correlation between this variable and the ability to hold members also. The assimilation rates for these churches was shown to be 0.0 percent, 50.0 percent, and 69.2 percent, respectively over the six-year period studied. Note that church \#3 had the most even spread in member ages, was the church with the highest

${ }^{1}$ Lyle E. Schaller, "Twenty Questions for Self Evaluation in the Small and Middle Sized Church," Church Management 8 (April 1977): 15, 16. 
rate of retention, and was the one in which the number of members with tenures of over ten years was the lowest.

Members' Experience with the Local Church

Questions $14,15,22$, and 31 dealt with the members' satisfaction with their local church. Members in small churches usually show a high degree of satisfaction in their church environment. As mentioned earlier in this paper, this satisfaction can sometimes block them from perceiving the needs of new members that come among them. As expected, the overall satisfaction and church involvement were high. Over three quarters reported that they had friends in the church, and the age group with the most friends was the zero to five years tenured group ( $81 \%$ reporting positively). Fifty-eight percent of those taking the survey held church office in their local fellowships, suggesting a high degree of involvement. This also is a high indicator of satisfaction. An average of 70 percent reported, "I am happy with the fellowship this church gives me." Interestingly, the only group that did not concur with this percentage was those members tenured locally for six to ten years. Their percentage of satisfaction was only 44 percent. The final indicator of satisfaction shows that 77 percent gave an "agree" or "strongly agree" rating to the statement, "This church meets my needs." This concurs with the findings on the other questions of this type and supports the literature regarding the satisfaction small-church members feel with their local church fellowships.

Member's View of the Church's Mission

Seven questions on the survey dealt with this area. Question 5 asked how many believed God was calling all people to become seventh-day Adventists. About two thirds of the church members marked this question 
in the affirmative. This response was lower than expected from a church that believes as a tenet of its faith that it comprises the remnant of God's people on the earth. Apparently one third of the membership of these churches have doubts in the matter, which can certainly dampen any climate for growth and assimilation. Those who believe that God may not be calling people into their church will be less likely to expend their personal energies to include new people in their fellowship than those who do.

The numbers improved somewhat for question 7, "My church has lots to offer this community," with 80.5 percent responding in the affirmative. Question 11 made a similar statement, "Many people in this town need the fellowship this church can offer." The response here was 91.9 percent. So the membership seems to feel they have something good to share with others.

Likewise, there was a high degree of certainty concerning the local church's role in the community. To question 10 almost 80 percent responded "yes" to the statement: "We know what God wants us to do locally as a church in this community." Members also indicated an awareness of the need for their personal help and assistance in running the local church outreach program (question 16, 70.7 percent answering in the affirmative). And there was an almost universally felt need among the members to improve their outreach program (question 20, 97.6 percent affirming).

"The church is to be a hospital for sinners and receive everyone who comes here for membership." This statement, question 6 , met with a 908 positive response. People in these churches recognized that perfection was a long way off, and that it is the place of the church to receive anybody who is willing to come into its gospel treatment program. Only about 10 percent felt the church must be more selective 
in its admissions. These may tend to be the screeners, who see their function as keeping the church pure.

Membership's Commitment to the Church's Mission

It is interesting to compare the above, heavily positive views, to the actual behaviors the church members involved themselves in with respect to new members. Table 10 can be helpful here.

Table 10.-- The progression of member responses moving from concept statements to behavior

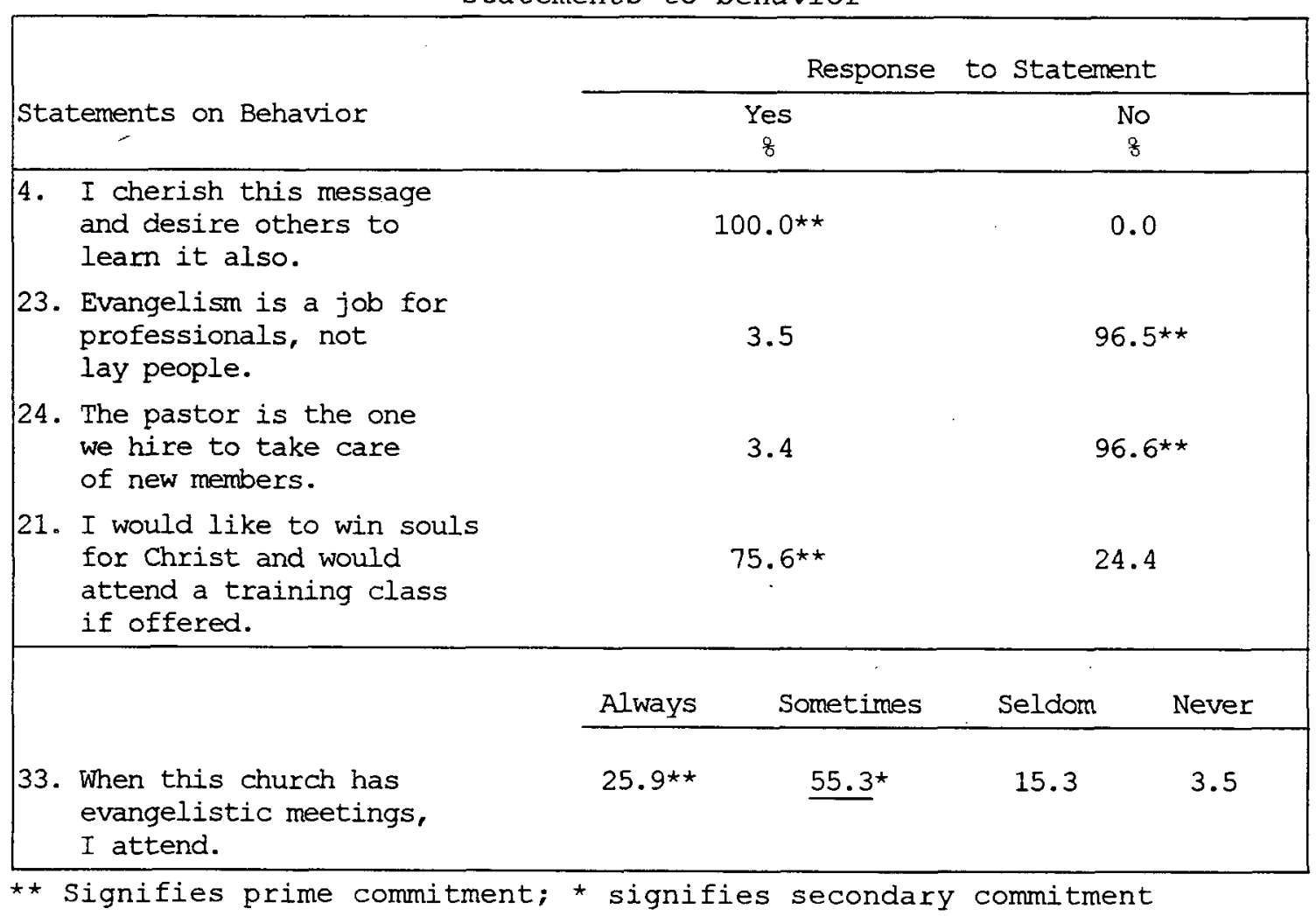

This table begins with an ideal statement (\#4): "I cherish the message I have learned in this church and desire others to learn it also." It ends with a statement of personal behavior needed to act out this statement (\#33): "When this church has evangelistic meetings, I attend." One hundred percent answered in the affirmative for the first 
statement, but only about one quarter of the people taking the survey said they "always attend" evangelistic meetings when held. Personal commitment to mission has a greater price than personal views and theories. A drop in percentages was expected here, therefore, and a drop in percentages is what was received.

Membership's Attitudes toward Assimilation of New Members

One of the items that will strongly enhance or restrict the ability of a new member to become part of a congregation is the attitude the members of that congregation express toward new members. If the membership likes the church as it is--thinks it is just the right size right now--it will likely make new people feel unwelcome in order to preserve its comfort zone. If, however, the congregation feels a need to expand, it will be inclusive. In the questions under this section, the survey looks at the attitudes of members in this area.

In statement 8 , people indicate that their churches are not growing fast enough to suit their ideals. The response to statement 34 concurs, strongly rejecting the idea that the local churches are "big enough already." A high percentage also (98.9\%) indicated in statement 17 that their churches needed to reach out and bring in new members from their communities. But when the church does reach out, are they ready to welcome the new believers?

Statements 12, 19, and 29 show how the people feel toward putting themselves out for new believers. Of the respondents, 98.8 percent recognize the need for church members to be friendly and supportive. Likewise, the majority (to the 88 th percentile) recognize that it takes more than putting signs on the restrooms to make new members feel at home, and some special treatment, "coddling," is acceptable to the congregations if it is not overdone. It would appear that these members are ready to receive new people. 
Membership's Behavior toward

New Members

Things become disappointing again, however, when personal

behavior is evaluated. It is easy to say we want to receive new

members, but do our actions testify that our words are true?

Again, the progression from ideal to real is tested by actions.

To statement 25, "I believe in actively including new members in what I

am doing in this church," 92.9 percent of the members gave an

affirmative response. However, there is reason to question the reality

of this. Statement 27 shows that nearly 88 percent of the members will

at least speak to newcomers when they show up (to the "always" or

"sometimes" levels at least). However, the response to statement 28

shows that only 35 percent of those who were able to do so ever invited new people to their homes ( 78 always; 298 sometimes). The majority of the members who could do so, ignore this means of hospitality. Again, in statement 30 , we see that the majority of members (808) only

"sometimes" try to introduce new members into their social groupings.

This should be over 80 percent "always" including new believers, especially since nearly 100 percent of those taking the survey profess to believe in doing this very thing. Our churches need more dedicated people to include these new believers into the fellowship of the church. This is one of the reasons why our church members should all attend the evangelistic meetings their churches hold in their communities. It is at these meetings that they can meet new believers, befriend them, and so help them in the decision-making process to become active parts of the new church body we are trying to attract them to. This is why the response to statement 33 is also disappointing from the aspect of assimilation. 
Membership's Evaluation of the Church's Performance toward New Members

Statements $9,13,18,26,32$, and 35 through 40 deal with the membership's evaluation of themselves and their church's performance. The general, overall self-approval rating is high. Most believe the church is warm and friendly, and it probably is to members. However, some uncertainty is indicated in a drop of percentage points into the high to low $60 \mathrm{~s}$ when asked if the people of the church really care for each other and if it is easy for newcomers to find a place among them.

Probably one reason for this is that they have seen so many newcomers leave. Statement 32 shows an interesting pattern. When asked if new members tend to stay, most of the membership answers "sometimes," in the 80 th percentile, but only 4.7 percent indicate anything for the "always" answer. This suggests that the interpretation they have given to "sometimes" is rather loose and might better be shifted to the "seldom" area of our understanding. It is hard to admit to failure, so we, as humans, tend to grasp the highest evaluation for ourselves that we can talk ourselves into. Some stayed, we reason, therefore it is proper to indicate a "sometimes" in this answer.

In statements 35 through 40 the members were asked to step back and take a look at their church from the aspect of a person newly baptized and attending services there for the first time. What would they experience there? Of course, complete objectivity is not possible here, but the tendency in the responses is still instructive.

The questions were made to be as concrete as possible, focusing on the types of actions that the new member might encounter at the church. Again, the church tended to evaluate itself positively, in and about the 70th percentile, concerning such things as, "Would someone speak to you" or "Would you find a Sabbath school for your children?" Most felt they would leave having made friends and would come back next 
week. However, uncertainty appears when asked if someone would invite them home. There the "not sure" response was used by nearly 40 percent of the participants. And no wonder, since most of them had just indicated that they invited people home only on rare occasions, who would be there willing to invite them if they came to their church as visitors?

The Follow-Up Questionnaire and Its Comparisons

In the follow-up questionnaire, given to those to took the seminar only, certain assumptions are involved. First is that those who took the seminar entered the seminar with the same general points of view as those who did not (i.e., their average score on the survey if taken right before the seminar would be the same as that of the whole church). Corollary to this first assumption is the supposition that those attending the seminar are a representative cross section of the entire congregation involved. The extent to which the follow up testing is able to show a change resulting from the seminar is based on the validity of these presuppositions.

It was further assumed that the people who populate our small churches are mostly good people. They feel the desire to see new members join with them in this message, and they are committed to helping this to take place. If this is true, the belief is that they need only to be informed of the needs that new members encounter to become more effective. The seminar therefore focuses on providing this information, both experientially and cognitively. The final questions of the follow-up questionnaire were therefore revised to ask for commitments to various behaviors that would help new members become incorporated into our churches. For the purpose of evaluating the seminar's effectiveness, these things should be kept in mind. 
Again, the follow-up questionnaire is found in its entirety in appendix $B$. In this space the various areas of testing are revisited to see what changes may have taken place in their scoring. Only those questions showing a change are dealt with here.

\section{Membership Demographics}

In member demographics, several important differences are noted among those who came to the seminar and took the follow-up questionnaire. First among them is a shift in the tenure of these members in the local church. The results of the questionnaire show that it is the newer members in the church who attended the seminar. Those who had been members from zero to one year showed a 9 percentage point increase (hereinafter to be referred to as "point" increase or decrease). Those who had been members from one to five years showed an 8.2 point increase. Correspondingly, those who had been members from six to ten years decreased by 2.8 points, and those above ten years tenure in the local church decreased by 9 points. Non-members attending the seminar were also down by about 5.9 points. This could show that the longer-term membership is less open to change, or it could show that the members are more elderly and simply less able to attend.

When looking at the ages of those attending, an interesting thing is seen. In the age categories of those attending the seminar, members under twenty years of age were not represented at all in the seminar (a decrease of 2.3 points) and those from twenty to thirty years of age dropped in their attendance by 7.8 points. It was primarily the members in the age range from thirty-one to fifty years who showed enough interest to attend (increased by 12.9 points). Those aged fifty-one to sixty-five also dropped about 7.9 points in attendance, but the truly elderly, those over sixty-five years of age, were almost a quarter of those attending (a factor of 6.1 points of increase). The 
reason why many of the younger members stay away may be again that they do not care, or that they have small children and cannot attend because of them.

One other interesting change in the demographics of the two groups can be noted. While approximately 15 percent of those attending the church claimed to have come into the church through evangelism, none of this group attended the seminar. There was also a significant drop in attendance among those who had come into the church by Bible studies. The bulk of those attending the seminar were from those who had grown up in the local church (biological growth up by 4.2 points) or from those who had come in through other means, possibly transfer (19.2 point increase). The reason for this lack of interest among those whom one would feel should be most interested is a mystery.

Members' Experience with the Local Church

Regarding their personal experience with the local church, those who came to the seminar felt about the same way as those who did not attend the seminar, as evaluated through the overall questionnaire. In fact, a higher percentage of them were involved in the local church through church office (increased by 8 points). They expressed the same degree of satisfaction with the local church and felt the local church fulfilled their needs to the same degree as the original sampling (about $70 \%$ in each category, respectively).

The one notable change is seen in those members whose tenure in the local church has been only from zero to five years. When asked if they had many friends in the church, a question that is usually related to individual satisfaction, only about half had friends in the church. This is a decrease of about 31 points for that group of members. overall, however, the decrease for this question was not significant (only 2 points). 
It would appear that with respect to personal experience with the church, there is little difference between the two samplings of the memberships of these churches. This would tend to help strengthen the above mentioned assumption of a representative sampling (even though the demographics of the group by age, etc., seem to have changed considerably).

Members' View of the Church's Mission

In this area there were only three significant increases to be noted. In all other questions, things remained about the same as in the overall survey. This means that the personal view of mission of these members remained about the same, except for an increase in their belief that God is calling all to become Seventh-day Adventists (increase 5 points). They believed more strongly than the former group that their church has a lot to offer their community (up 12 points). And they expressed the unanimous belief that their church needed to develop a better outreach program to that community (up 2 points). This last area appears to be one of the major needs felt by the Adventist peoples surveyed.

Membership's Commitment to the Church's Mission

In this area, the seminar attendees showed significant positive change over those who did not attend. As in the first questionnaire, they unanimously indicated that they cherish the message of this church, but they followed up by a determination to be involved in that message. Table 11 lists their responses and should be helpful. The second column shows the overall percentage of respondents answering affirmatively to the question, and the last column indicates the number of percentage points change over the former survey and the direction of that change. 
Table 11-- Answers to statements showing personal commitment

\begin{tabular}{|l|c|c|}
\hline \multicolumn{1}{|c|}{ Statement } & $\begin{array}{c}\text { Affirmative } \\
\text { Response }\end{array}$ & $\begin{array}{c}+/- \\
\text { pts }\end{array}$ \\
\hline $\begin{array}{l}\text { 4. I cherish this message \& desire others to learn } \\
\text { it. }\end{array}$ & 100.08 & 0 \\
\hline $\begin{array}{l}\text { 21. I would like to win souls for Christ and would } \\
\text { attend a training class if offered. }\end{array}$ & 97.18 & +21 \\
\hline $\begin{array}{l}\text { 23. Evangelism is a job for professionals, not lay } \\
\text { people. }\end{array}$ & 0.08 & -3 \\
\hline $\begin{array}{l}\text { 24. The pastor is the one we hire to take care of new } \\
\text { members. }\end{array}$ & 0.08 & -3 \\
\hline $\begin{array}{l}\text { 33. When this church has evangelistic meetings, I } \\
\text { will attend. (Always) }\end{array}$ & 51.38 & +25 \\
\hline
\end{tabular}

It should be noted that all statements in this part of the questionnaire do not indicate a positive change toward new member assimilation if answered in the affirmative. Statements 23 and 24 are worded so that an affirmative response would actually indicate a negative attitude toward the care and feeding of new members. Therefore, a negative score in the third column for statements 23 and 24 is a very positive change with respect to assimilation.

It can be seen that those completing the seminar are much more ready to reach out to new members than those who did not attend the seminar. Also, the change in the last question from evaluating past behavior, which would not have changed in the month's time after the first questionnaire was given, to the making of a commitment for the future needs to be noted here. It is a different question. At this point, it indicated an individual's desire to be more involved with new members in the evangelistic church setting and no more. However, it is significant that over half of the participants in the seminar indicated affirmative responses at the highest level (always). 
Membership's Attitudes toward Assimilation of New Members

Although most responses in this area remained about the same as those previously mentioned, significant change was noted in the answers to questions 29 and 34. Question 29 suggests that the church should not give special treatment to new members to help them enter its fellowship more easily. It was good to see the attitude here shift away from an affirmative position where this statement was concerned. Whereas in the first questionnaire, 4 percent "strongly agreed" with this statement and about 20 percent "agreed," the follow-up survey showed that only about 2.5 percent "strongly agreed" and 16 percent "agreed" who had taken the seminar. Also, there was a deepening of the opposition to the statement as seen in a rise to 28.9 percent who "strongly disagreed" with the statement among seminar attendees, an increase, here, of about 12 points.

Likewise, in question 34, when faced with the statement, "This church is just the right size in its membership," respondents after the seminar indicated even more categorically that there was room in their midst for new members. The shift toward the "strongly disagree" response here was about 12 points also. The significance here is that if church members are satisfied with their size as a congregation they will seek to keep it that size, even if it means screening out new applicants .

Membership's Behavior Toward New Members

Many of the statements in this area of the questionnaire were modified so that they would now reflect the member's attitude toward future performance with respect to new members. The reason for this is that past behavior cannot be changed, but future behavior is as yet to 
be expressed. Therefore, intentions are being substituted for behaviors wherever necessary.

The results in this area could prove very helpful to the local church if carried through into the future behavior of its participants. Table 12 shows the results of the four questions involved.

Table 12.-- Members' commitment to assimilate new members

\begin{tabular}{|l|c|c|}
\hline \multicolumn{1}{|c|}{ Statement } & $\begin{array}{c}\text { Affimative } \\
\text { Response }\end{array}$ & $\begin{array}{c}+/- \\
\text { pts. }\end{array}$ \\
\hline $\begin{array}{l}\text { 25. I believe in actively including new members in } \\
\text { what I am doing in this church. }\end{array}$ & 100.08 & +7 \\
\hline $\begin{array}{l}\text { 27. I will try harder to speak to new members and } \\
\text { make them feel at home any way I can. (Always) }\end{array}$ & 76.98 & +36 \\
\hline $\begin{array}{l}\text { 28. I will be inviting new members to fellowship at } \\
\text { my home this year. (Strongly Agree) } \\
\text { (Agree only) }\end{array}$ & $\begin{array}{l}18.98 \\
64.98\end{array}$ & -17 \\
\hline $\begin{array}{l}\text { 30. I will try harder to introduce new people to my } \\
\text { friends at the church. (Yes) }\end{array}$ & 82.18 & +61 \\
\hline $\begin{array}{l}\text { 33. When this church has evangelistic meetings I } \\
\text { will attend. (Always) }\end{array}$ & 51.38 & +25 \\
\hline
\end{tabular}

The strong showing toward helping with the assimilation process is evident in these responses. The primary reasons why new members often leave our fellowships is that they feel screened and unwanted, not a part of what is going on at the local churches they join. They have not made friends in the congregations to help them through these feelings. Therefore, they leave. When church members make it their business to include newcomers and to help them become a part of their network of friends in the church, many of these needs will be met.

Membership's Evaluation and Commitment to Improve the Church's Performance toward New Members

Some of the responses in this section showed little increase or decrease. About the same percentage of participants felt that the local church was a "warm and friendly place" and that "the people in the 
church cared about one another," and to about the same degree.

Interestingly, they evaluated their church better than the initial

questionnaire in the ease with which new members could become a part of the church family. This showed an increase of 9 points over the former results. There was a slight shift to the negative to the statement, "This church is friendly to visitors and makes them feel at home," but not too significant. Perhaps this is because these questions, unchanged from the first questionnaire, have a strong orientation to the past and you cannot change the past.

Great difference begins to be seen, however, in the responses to statements regarding commitment to make things better in the future. The number indicating that they would "always" do all they can to help new members stay active was 84 percent. All the rest fell into the "sometimes" category. This is a 79-point increase over responses to the former statement: "New members who join this church stay active in its fellowship." If these members carry through with their desire to always help new members any way they can, more new members will end up staying. The final five questions are also oriented to building for the future, and as such are changed enough so that the increases they show over the former questions need to be interpreted in the light of their new future orientation. Still, the results are encouraging.

In the former questionnaire the questions in this section asked the member to imagine him/herself coming to church for the first time and what kind of reception he or she would get in five key areas. In this follow-up survey, members were asked to commit to giving aid to new members in those same five specific areas. It is therefore assumed that the change in percentage will indicate something of an increase or decrease that new members can expect in these areas when attending their church. 
Question 35 asks if the members would help new members by introducing themselves to them so they will feel at home. This showed a shift to the central position. Members here seemed unsure of what they would do. Still, 78 percent said they would introduce themselves and try to help newcomers feel at home in their church fellowship. This question needs to be compared to the response to question 27 , which asks if they will try harder to speak to new members, etc. In this former question, 76 percent said they would always do this for new members. That is about the same as the response to question 35, but notice that question 27 had originally been 36 percentage points lower with respect to the "always" response. This suggests that when filling out the first questionnaire, people tended to "fake good" for their churches on the last six questions. In the post-seminar questionnaire, we see members determining to live up to their positive view of the church. The remaining questions in this section show significant increases in the members' desire to help. Question 36 suggests that newcomers can expect a 29 percent increase in the willingness of church members to extend to them the hospitality of their homes. This is the area that was treated with the most uncertainty in the former questionnaire. New members should also find that 92 percent of the seminar attendees will introduce them to their friends and family (an increase of 15 points), that 83 percent will help them with their children (increase of 9 points), that 100 percent would be friendly to them (positive by 25 points), and that they would receive an invitation back to church from 1008 of the seminar attendees (an increase of 18 points). Even though only a fraction of the members attended the seminar, it is easy to see that the church atmosphere toward new members that they will represent can be a very positive help in the processes of incorporation. 
Observations on Church Behavior Beyond the Questionnaires and Their Possible Meanings

There are some concerns, however, to be seen in the church's overall behavior with respect to the seminar itself. Bear in mind that these seminars were conducted at the request of the local church boards in each of the three churches. Yet, attendance at the seminar by the members of these churches was sometimes very low.

Answers to Questions versus

Seminar Attendance

This begs the question of honesty on the part of the church members in filling out the original questionnaire. When people who are church members say, in effect, that they are eager to see their church grow, and that they are willing to do what they can to help it grow (that new members are welcome among them even though they recognize that many new members are not staying among them), it is strange to see so few set the time aside to seek to discover how to help their fellowship become more magnetic to new people. The old adage that says "You speak louder by what you do than what you say" is applicable here. One church in the study had over 80 members. It invited the seminar to come to its premises. But on the day of the seminar, less than half of the membership was present. Of that body, only eight attended the seminar and only one of them had taken the former questionnaire. Is that church interested in growth or in becoming more inclusive to new members? If so, why was it so restricted in its attendance?

It can be wondered, from this, how much of the literature, which states that much of a church's negative actions toward newcomers are unconscious, is reliable. Perhaps what is really happening is more conscious than we supposed. Church members who resist change may do so because they actively like things the way they are, regardless of what they will tell a researcher. But because they are conscious of their 
true desires, and they realize that their desires constitute sin in the eyes of God and the church, they try to avoid those places where they may have to confront themselves on these issues.

Answers to Concept Questions versus Behavioral Questions

The existence of this contradiction in many of our church members is also observable in their answers to concept questions and statements when compared to their answers to behavioral questions and statements. It is easy to say, "I cherish this message and want others to learn and believe it." It is another to say, "When evangelistic meetings come to my church, I always attend." It is a simple matter to say that "New people who attend our churches should all receive invitations to a member's home for fellowship dinner." But it is not so easy to affirm "I always try to invite visitors home for fellowship dinner" if one is not, indeed, doing so. It was interesting to note the differences in this area. It is important to keep in mind that, to achieve genuine results in increasing member awareness of the needs of new members, action and behavior must be the goal, and not statements of intention only.

In this, the weakness of the seminar, and the questionnaire as an evaluative instrument, is emphasized. When all the counting and comparing is finished, all the information this instrument has communicated and the evaluation thereof is only a piece of paper. The prospects for change will ever belong to the local congregation and the individual members. They must put their stated intentions into practice before results can truly be achieved. 


\section{Program Evaluation}

The stated purpose of this project was to seek to increase the awareness of church members concerning the assimilation needs of new members in our congregations. The means for this stimulation was to develop a seminar at which this objective could be reached. Measurement of success in reaching this objective was to be gained by comparing the results of a questionnaire given to the church before the seminar was held with the results of a very similar questionnaire to be filled out by seminar participants following the seminar. It was projected that the seminar should produce some change in the attitudes of members as indicated in these questionnaires. In order to provide time for evaluation, the initial questionnaire was presented one month before the scheduled date of the seminar.

In seeking to reach these objectives, some things went well, while others were disappointing. I feel the seminars were well received by those who participated in them. Positive attitudes were expressed concerning the material presented throughout the presentations and many questions were asked. The participants seemed, for the most part, to genuinely care about the records of their individual churches in assimilating new members. However, the percentage of church members attending the seminar was low. The attendance rate at one church was only about 208 of those attending the service that day--eight people in all--and only one of those had filled out the former questionnaire. Interestingly, but not too surprisingly, seminar attendance by the smallest church was the greatest, percentage wise. That church, having only about 22 people in attendance the day of the seminar, had an attendance at the seminar of 12 participants, 10 of whom had taken the first questionnaire. That was about 54 percent of those in church that day and 53 percent participation of those who had taken the first questionnaire. 
The overall lack of attendance on the part of the churches involved, however, brings up some uncomfortable questions, both with respect to the membership of our churches and with respect to the seminar evaluation process. Regarding the latter, can the results of the post-seminar questionnaire be considered valid for the purposes of comparison with the first questionnaire as an evaluation of attitude change in the congregation, or even of the participants in the seminar? Proper evaluation could be based on a one-on-one correlation with the first sampling or on a testing of a representative sampling of the congregations in which the seminar was presented. Since it is clear that the same people did not participate in both questionnaires to the same extent, the result is uncertain from that point of view.

Concerning a representative sampling, it was already pointed out in the section on seminar results that there were some similarities in the demographics of those who took the two questionnaires. There were also differences. The follow-up questionnaire did show some desired changes might have taken place in the thinking of the members who attended, but these may be tenuous.

It may be that the seminar attracted those who were already interested in helping new members, and that the follow-up questionnaire only reflected the current beliefs of that subgroup rather than attitude changes in their actual feelings. In this case the seminar could be said to be of no effect in producing change, or at the most, that it only strengthened what was already present in the participant's thinking. Or it may be that the seminar did indeed cause some of the change measured in the follow-up testing. But this latter cannot be measured by that testing. Therefore, with respect to the evaluation of the seminar and its effectiveness, this project should be judged a failure. 
One church in the process, however, may provide some idea on whether the seminar was helpful or not. The smallest church, having a relatively higher participation in the seminar of 54 percent of its membership, could indicate a truer trend. It is interesting that in comparing the results of its post-seminar questionnaire with the results of the questionnaires taken in other churches, the changes in thinking still move in the same generally positive direction with respect to assimilation. This corroboration of results, while not as conclusive a measurement as hoped for, gives support to the idea that the seminar did cause some growth in the thinking of its participants.

Also, there were many insights to be gained from other sources than the comparison of the questionnaires relative to the seminar. The information gathered on the thinking of the members from the small churches involved, and the subjective evidences regarding their willingness to open themselves to new people (i.e., the willingness of church members to attend the seminar and their responses in it along with the general information gleaned from the first questionnaire), is of value from the standpoint of determining where our church members are in their present thinking on the matter. There are strong sociological, psychological, and even theological barriers that need to be overcome to produce the receptiveness within our churches that will be needed for future assimilation.

The questionnaire shows that very few in the churches tested believe the pastor and evangelist are to do everything with regard to evangelism and incorporation of new members. This differs from the trends of a few years ago, when the pastor and evangelist did everything. What is needed now is to build new behaviors based on the theological understanding that the church membership has a major part in producing and nurturing the growth the gospel requires. The training and equipping work of the church pastor has yet to be fully accepted by 
a membership willing to do "the work of the ministry" spoken of by Paul in Eph 4:12. And the membership at large in these churches has not yet shown itself psychologically and sociologically ready to perform these functions. But it is evident that there is a minority among them who will respond to this call of the gospel, and they can become a seed for further change.

Admittedly subjective observations in the churches under my care that have participated in the seminar indicate that some of the changes that the church committed to in the follow-up questionnaire have begun to take place. This is especially evident in my smallest church, which has had no Sabbath school for children for many years. Members have become willing to dedicate more of their meager resources to the ministry to children. As a result, some children are beginning to come to church worship services. I can only pray this church will succeed in making them and their parents welcome.

My other church has been growing in its inclusive nature over the past year as well. However, since I am the preacher, and my sermons often emphasize the needs for inclusiveness with respect to new members and old, this growth probably does not have as much to do with the seminar as it does with the entire program of the church over time. That church has had baptisms over the past year, most of which resulted in kingdom growth. For the most part, those baptized have become integrated into the fabric of the church fellowship. Indeed, many of them have become points of contact through whom the church is reaching others as well. This church has grown to exceed the hundred-member limit delineating the churches to be included in this study.

The third church in this study seems to have remained about the same. It is the one that showed the least interest in the seminar on assimilation, which is interesting because it was also entering into evangelistic meetings at about the same time the seminar was held in it. 
There has been no notable growth there as a result of those meetings. No baptisms were reported. The seminar seems to have produced little effect in helping this church. Yet, within that church, the small core of those who attended the seminar want to see change and could be nurtured to help produce it.

It is felt that the seminar developed in this project cannot be counted on to produce the desired changes in small congregations by itself. However, it can be a valuable part of a larger program of teaching, preaching, and mentoring by which the local church can be stimulated to change. 


\section{CHAPTER 5}

\section{CONCLUSIONS AND RECOMMENDATIONS}

Overall, it is my opinion that the membership of smaller churches can be led to see their responsibility to become includers and assimilators. The prospects for change, in their highly fraternal environment, will need a steady influence from their pastoral leadership as well as from the conference administrations in order to get their attention and direct it to this goal.

Seminars, such as the one used here, can be a part of the process initiating the change. However they should be expanded into a more comprehensive form, taking, perhaps, one Sabbath per month for three consecutive months to impart information tailored to the local environment along with assignments for application of the techniques involved. Skills ${ }^{1}$ in including people outside the primary group need to be identified and a teaching sequence developed for use in these seminars, for simply teaching information about assimilation will produce little.

It is also noted in this study that the traditional congregational structure favored in most Seventh-day Adventist fellowships is resistant to growth. Once the congregation reaches a certain optimum size, it no longer has room for new people who may desire to join with it. Members, therefore, need to be organized into new patterns of fellowship that will allow for expansion and division

${ }^{1}$ Some examples of the skills that could be included here are concepts of simple friendliness and hospitality, listening and perceptive skills to open the membership up to the needs others express verbally and nonverbally, even some training in group dymamics for those who feel they might learn to lead out in group ministry. 
when necessary. In this way, room will be always available for new members to become involved and to use their gifts in ministry.

Seventh-day Adventist churches have been resistant to this type of change in the past (as, I assume, any primary group would be). Methods, therefore, need to be developed to help our membership to see the advantages of developing around a cell-group structure for the purposes of completing the commission to effectively carry the Three Angels' Messages to their present communities.

Along with seminars and restructuring, however, preaching and teaching are necessary to develop a vision within each church of the goal to be achieved. Members should understand the needs of newcomers and be involved in the vision before it can ever become a reality. A search of the Bible and the writings of Ellen white could be invaluable in helping members to see the divine plan for growth. Sermons can be written on the early church and its social structure as well as the use of class meetings used by the Methodist revival in the 1800 s. Ellen White's reference to small group structures, like "small companies," should be explored and presented. The importance of each person gaining opportunity to express his or her gifts in ministry can be emphasized from the pulpit and in the classroom.

Since the footmen need leadership, the colleges and seminaries need to produce leaders who support the vision of an involved laity, each fellowshipped in his or her own small group, dedicating their talents to ministry. The existing pastoral force also needs training at workers' meetings to bring it into harmony with the concepts of a revived church structure and an active, ministering laity. Finally, those lay people, themselves, who have the gifts of pastor and teacher need to be included in training events that will enhance their abilities to strengthen their brothers and sisters in the church and work with the pastoral force in preparing the church for victory. 
Tools also need to be developed to evaluate our churches to see which are most ready for growth and assimilation of new members and which are not. This would be of great help in evaluating a church beforehand to see if it is ready for evangelism. There is little purpose in holding meetings to bring new people into the message if the church preaching that message is not prepared to receive them. Research could be done in this area to map out the developmental stages a church body might go through to become a vibrant powerful exponent of its message in its community. It could then be determined at what stage an individual congregation might be in this process and what methods might be used to help it to the next necessary step in its maturity and effectiveness.

With respect to the research done in this paper, it is suggested that in any endeavor to test for change of attitude in a given congregation following any stimulus event, it is the whole congregation that should be tested the second time, not only those who have attended the event. If the event has had an effect, that effect should become apparent over time for the entire body of the local church. And since the sample tested remained basically the same for both testing instruments, the results would be measurable. It is also suggested that pre- and post-event testing be done to evaluate the effectiveness of the event for promoting change in its participants.

But we should not rely upon one or even two stimulus events to produce change. Change can only be sustained if it is continuously and patiently worked for through as many stimulus events as possible, including continuous mention of the vision through the sermon and the class-room. Then people will begin to become accustomed to the vision and follow it. 
APPENDIX 
APPENDIX A

THE TEN-CHURCH SURVEY AND ITS RESULTS 
Resulting Information from the Ten Church Survey

Regarding Church Retention for

New Believers, 1988 - 1993

1988

Joined
1988

Retained Source

1994 EvanMtng

Source
Bio

Source

Church \#1

Church \#2
Church \#3

Church \#4

Church \#5

Church \#6

Church \#7

Church \#8

Church \#

Church\#10

$\begin{array}{ll}0 & 0 \\ 0 & 0 \\ 2 & 2 \\ 1 & 0 \\ 0 & 0 \\ 1 & 0 \\ 0 & 0 \\ 5 & 5 \\ 0 & 0 \\ 0 & 0 \\ & \\ 9 & 7\end{array}$

1989

Joined

Joined
1989

Retain EvanMtng

Source

$\begin{array}{ll} & 2 \\ 1 & 1\end{array}$

2

1

4 trans

Percent Retained $1988=77.8 \&$

Source Multiple

Church \#1

Chureh \#2.

Church \#3

Church \#4

Church \#5

Church \#6

Church \#7

Church \#8

Church \#9

Church\#10

$\begin{array}{ll}0 & 0 \\ 1 & 0 \\ 4 & 1 \\ 1 & 0 \\ 0 & 0 \\ 3 & 3 \\ 5 & 5 \\ 2 & 2 \\ 0 & 0 \\ 1 & 1 \\ & \\ 17 & 12\end{array}$

$17 \quad 12$

$\begin{array}{llll}2 & 2 & 1 & 1 \\ 1 & & 1 & 1 \\ & & & \\ & 5 & 5 & 5 \\ & 2 & & \end{array}$

Overall

Retention

by Church

by Church

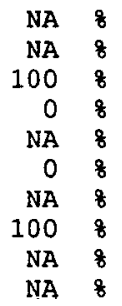

100.08

83.38

69.28

50.0

50.08

78.88

61.58

81.0

40.08

$68.8 \%$

Total whole Sample $=70.5$ \&

Total

Joined

by Church

$\begin{array}{rr}\text { of } & 3 \\ \text { of } & 6 \\ \text { of } & 13 \\ \text { of } & 4 \\ \text { of } & 6 \\ \text { of } & 33 \\ \text { of } & 13 \\ \text { of } & 42 \\ \text { of } & 10 \\ \text { of } & 16\end{array}$

of 146 


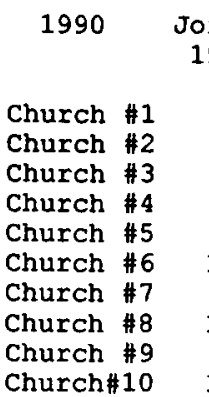

Joined Retained Source 1994 EvanMtng

Source

Source Multiple

Persmin Source

$\begin{array}{rr}1 & 1 \\ 0 & 0 \\ 0 & 0 \\ 2 & 0 \\ 6 & 3 \\ 13 & 10 \\ 5 & 1 \\ 12 & 7 \\ 5 & 0 \\ 10 & 6 \\ & \end{array}$

$\begin{array}{lll} & & 1 \\ & & \\ & 1 & 1 \\ 6 & & 6 \\ 2 & 3 & 2 \\ 1 & 6 & 1 \\ 3 & & 2 \\ & 9 & 2\end{array}$

1

Percent Retained $1990=51.9$

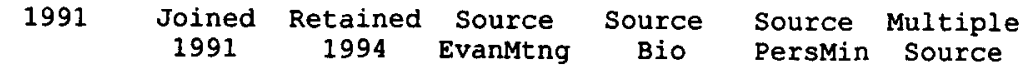

Church \#1

Church \#2

Church 44

Church 15

Church 115

Church \#6

Church \#7

Church \#8

Church \#9

Church $\# 10$

$$
\begin{aligned}
& 0 \\
& 2 \\
& 1 \\
& 0 \\
& 0 \\
& 2 \\
& 1 \\
& 8 \\
& 0
\end{aligned}
$$

20

1992

Joined

1992

Retained

d Source EvanMtng

$\begin{array}{llll} & 2 & 2 & 2 \\ & 1 & 1 & \\ 2 & & & \\ 2 & & 1 & 1 \\ 3 & 3 & 3 & 1 \\ 3 & & 3 & 3\end{array}$

Percent Retained $1991=85.0$

Source Source Multiple
Retention

by church

$\begin{array}{rr}100 & 8 \\ \text { NA } & 8 \\ \text { NA } & 8 \\ 0 & 8 \\ 50 & 8 \\ 77 & 8 \\ 20 & 8 \\ 58 & 8 \\ 0 & 8 \\ 60 & 8\end{array}$

Church \#1 Church \#2

Church \#3

Church \#4

Church \#5

Church \#6

Church \#7

Church \#8

Church \#9

Church $\# 10$

$\begin{array}{rl}\text { NA } & 8 \\ 100 & 8 \\ 50 & 8 \\ \text { NA } & 8 \\ \text { NA } & 8 \\ 100 & 8 \\ 50 & 8 \\ 89 & 8 \\ \text { NA } & 8 \\ 100 & 8\end{array}$

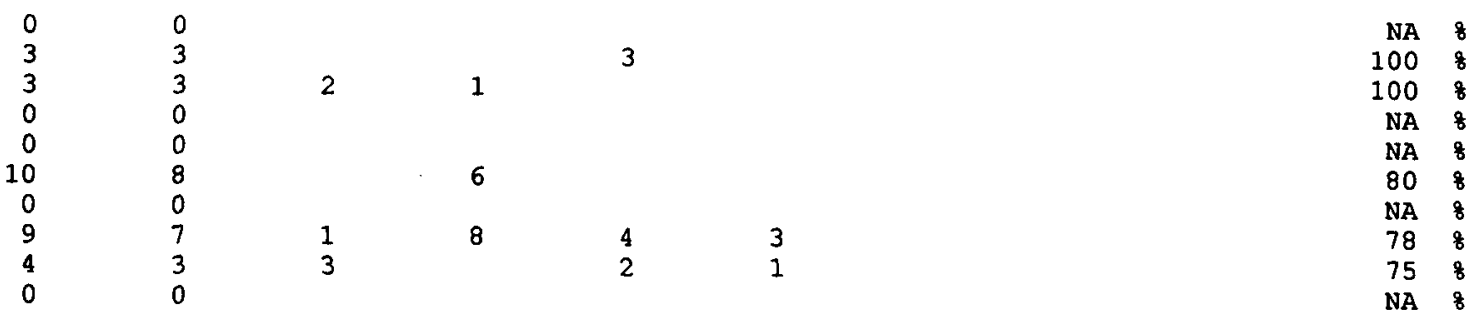




$\begin{array}{cc}1993 & \begin{array}{r}\text { Joined } \\ 1993\end{array} \\ & \\ \text { Church \#1 } & 2 \\ \text { Church \#2 } & 0 \\ \text { Church \#3 } & 2 \\ \text { Church \#4 } & 0 \\ \text { Church \#5 } & 0 \\ \text { Church \#6 } & 4 \\ \text { Church \#7 } & 1 \\ \text { Church \#8 } & 5 \\ \text { Church \#9 } & 1 \\ \text { Church } 10 & 2\end{array}$

17

\section{Retained Source} Source
EvanMting

Source

Source Multiple

Persmin Source

2

$\begin{array}{ll}2 & \\ 0 & \\ 2 & \\ 0 & \\ 0 & \\ 3 & 2 \\ 1 & \\ 5 & 2 \\ 1 & 1 \\ 1 & \end{array}$

15

1
1

1
1
1
2

1

Percent Retained $1993=88.28$
Retained

by church

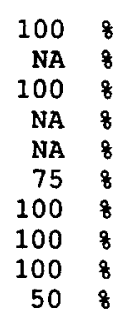

NA

100

NA 8

758

100

50

SPECIAL WORKUP FOR CHURCH \#5 1986 - 1990

$\begin{array}{ccccc} & \text { Joined } & \begin{array}{c}\text { Retained } \\ 1994\end{array} & \begin{array}{c}\text { Source } \\ \text { EvanMtng }\end{array} & \begin{array}{c}\text { Sou } \\ \text { B }\end{array} \\ 1986 & 4 & 3 & 2 & \\ 1987 & 17 & 6 & 11 \\ & & & & \end{array}$

Source Multiple

Persmin Source

$21 \quad 9$

100.08

27.38

38.58

Overall Percent Retained $=42.9 \%$

1987 was the year Leo Schriven held meetings at this church. 
Overall Percentages retained of those who came into the churches by:

$\begin{array}{lccc} & \begin{array}{c}\text { Total } \\ \text { Joined by }\end{array} & \begin{array}{c}\text { Total } \\ \text { Retained }\end{array} & \begin{array}{c}\text { Percent } \\ \text { Retained }\end{array} \\ \text { Evangelism } & -36 & 31 & 86 \% \\ \text { Personal Ministry } & 51 & 35 & 698 \\ \text { Biological } & 57 & 42 & 748\end{array}$

These figures not arrived at from charts above.

If extra 2 years for church \#5 are included figures are:

$\begin{array}{llll}\text { Evangelism } & 49 & 31 & 638 \\ \text { Personal Ministry } & 57 & 35 & 618 \\ \text { Biological } & 58 & 42 & 728\end{array}$

Retention in churches by size category (above or below 56-60 book mems.

Churches below 60 book members: Overall

church 2

church 4

church 9

church 10

asim rate

$\begin{array}{rr}83 & 8 \\ 0 & 8 \\ 40 & 8 \\ 69 & 8\end{array}$

Total

Average Rate $(x<60)$

Churches over 60 mem:

church 1

church 3

church 5

church 6

church 7

church 8

488

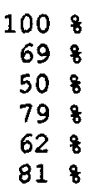

Total

Average Rate (60-100)
Real retention joined retained

$\begin{array}{rr}6 & 5 \\ 4 & 0 \\ 10 & 4 \\ 16 & 10\end{array}$

36 19

to

$53 \%$ 5 0 10 


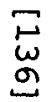


Church Survey of Baptism/Drop outs for Six Year Period

Church

Date

\begin{tabular}{|c|c|}
\hline Name & $\begin{array}{l}\text { Present Status } \\
\text { Active } \\
\text { Pactive Drooped. Trans. Dead }\end{array}$ \\
\hline John Doe & . 5-15-91 EF. $\quad x$. \\
\hline
\end{tabular}

Codes for Source of New Members: Evangelism $=E V ;$ Biolugical $=\mathrm{B} ; \quad$ Through a Friend $=\mathrm{F}$

Passtor $=\mathrm{P} \quad ;$ Lay Person $=$ LP; Bible Studies $=\mathrm{BS}$ 
APPENDIX B

QUESTIONNAIRES AND INTERVIEWS AND THEIR RESULTS 
Questionnaire on Member Attitudes

Toward Assimilation of New Members

Doctor of Ministry Project

Robert C. Williams

Please fill in the following information concerning your personal situation. All answers are confidential so please do not sign this questionnaire.

1. I have been a member of this local church for:

a. 0 to 1 year

b. 1 to 5 years

c. 6 to 10 years

d. More than 10 years

e. I am not yet a member

2. I am at the following age range:

a. Under 20 years

b. 20 to 30 years

c. $\quad 31$ to 50 years

d. 51 to 65 years

e. Over 65 years

3. I came to this church because:

a. I grew up in this congregation.

b. I attended evangelistic meetings held here.

c. I studied the Bible with an Adventist.

d. Other

The next series of questions are to determine your feelings concerning new people coming to your church. Please answer them as honestly as you can. When the choices don't exactly match your position, choose the one closest to your feelings. The only right answers on this questionnaire are the ones expressing how you actually feel.

4. I cherish the message I have learned in this church and desire others to learn it also.

5. God is calling all people to become

Seventh-day Adventists.

6. The church is to be a hospital for sinners and receive everyone who comes here for membership.

7. MY church has a lot to offer this community.

8. This church is growing fast enough already.

9. This church is a warm and friendly place.

10. We know what God wants us to do locally as a church in this community.

11. Many people in this town need the fellowship this church can offer. 
12. People need close friends who care about them in the church.

13. The people in this church care about each other.

Y N

14. I have many friends in this church family.

Y N

15. I am actively holding a church office this year.

Y N

16. This church needs my help to succeed in its programs.

Y N

17. I believe this church should "reach out" and bring in some new members from the community.

Y N

18. It is easy for new comers to become part of this church family.

Y N

19. The restrooms are marked. That's all we need to do for visitors.

Y N

20. We need a better outreach program in this church.

Y N

21. I would like to win souls for Christ but and would attend a training class if offered.

Y N

22. I am happy with the fellowship this church gives me.

Y N

23. Evangelism is a job for professionals, not lay people.

24. The pastor is the one we hire to take care of new members, I'd just get in the way.

25. I believe in actively including new members in what I am doing in this church.

26. This church is friendly

to visitors and makes

them feel at home.

Never Seldom Sometimes Always

27. I try to speak to new members and make them feel at home any way I can.

Never Seldom Sometimes Always

28. I have invited new members to fellowship at my home this year.

Does not apply Never Seldom Sometimes often 
29. The church does new members a disservice when it "coddles" them.

$\begin{array}{lll}\text { Strongly } & \text { Strongly } \\ \text { Agree } & \text { Agree } & \text { Disagree } \\ \text { Disagree }\end{array}$

30. I try to introduce

new people to my

other friends at

the church.

Always Sometimes Seldom Never

31. This church meets

my needs.

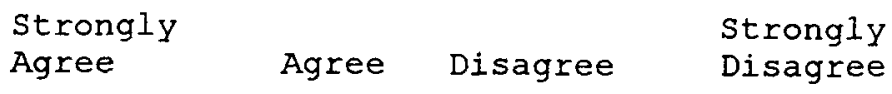

32. New members who

join this church

stay active in

its fellowship.

33. When this Always Sometimes Seldom Never

has evangelistic

meetings $I$ attend.

Always Sometimes Seldom Never

34. This church is

just the right

size in membership.

Strongly

Agree
Agree Disagree $\begin{aligned} & \text { Strongly } \\ & \text { Disagree }\end{aligned}$

In the following set of questions, imagine yourself to be a new interest coming to this church for the first time. You have just attended a series of evangelistic meetings held in the church. The only person you know by name is the pastor. Imagine what it would be like to enter the church. Then give the most appropriate answers to the questions below.

35. Would most people receive you

with a smile and help you

feel at home?

No Not sure Yes

36. Would you receive an

invitation to Sabbath

dinner in someone's home?

No Not sure Yes

37. Would people come up

and introduce themselves?

No Not sure Yes

38. Would your children (if any)

have a Sabbath School program?

No Not sure Yes 
39. Would you leave feeling you had made new friends?

No Not sure Yes

40. Would you come back next week? No Not sure Yes 
Follow Up Questionnaire on Member Attitudes Toward Assimilation of New Members

Doctor of Ministry Project

Robert C. Williams

Please fill in the following information concerning your personal situation. All answers are confidential so please do not sign this questionnaire.

1. I have been a member of this local church for:

a. 0 to 1 year

b. 1 to 5 years

c. 6 to 10 years

d. More than 10 years

e. I am not yet a member

2. I am at the following age range:

a. Under 20 years

b. 20 to 30 years

c. 31 to 50 years

d. 51 to 65 years

e. Over 65 years

3. I came to this church because:

a. I grew up in this congregation.

b. I attended evangelistic meetings held here.

c. I studied the Bible with an Adventist.

d. Other

The next series of questions are to determine your feelings concerning new people coming to your church. Please answer them as honestly as you can. When the choices don't exactly match your position, choose the one closest to your feelings. The only right answers on this questionnaire are the ones expressing how you actually feel.

4. I cherish the message I have learned in this church and desire others to learn it also.

5. God is calling all people to become Seventh-day Adventists.

6. The church is to be a hospital for sinners and should receive everyone who comes here for membership.

7. My church has a lot to offer this community. $\quad Y \quad N$

8. This church is growing fast enough already. $\quad Y \quad N$

9. This church is a warm and friendly place. $\quad$ Y N

10. We know what God wants us to do locally as a church in this community.

11. Many people in this town need the fellowship this church can offer. 
12. People need close friends who care about them in the church.

13. The people in this church care about each other.

14. I have many friends in this church family.

15. I am actively holding a church office this year.

16. This church needs my help to succeed in its programs.

17. I believe this church should "reach out" and bring in some new members from the community.

18. It is easy for new comers to become part of this church family.

19. The restrooms are marked. That's all we need to do for visitors.

20. We need a better outreach program in this church.

21. I would like to win souls for Christ and would attend a training class if offered.

22. I am happy with the fellowship this church gives me.

23. Evangelism is a job for professionals, not lay people.

24. The pastor is the one we hire to take care of new members, I'd just get in the way.

25. I believe in actively including new members in what I am doing in this church.

26. This church is friendly

to visitors and makes

them feel at home.

\section{Never Seldom Sometimes Always}

27. I will try harder to speak to new members and make them feel at home any way I can.

No Some Often Always

28. I will be inviting new members to fellowship at my home this year.

$\begin{array}{llll}\text { Does not } & \text { Strongly } & & \text { Strongly } \\ \text { apply } & \text { Agree } & \text { Agree } & \text { Disagree } \\ \text { Disagree }\end{array}$


29. The church does new members a disservice when it "coddles"

them.

$$
\begin{array}{lll}
\text { Strongly } & & \text { Strongly } \\
\text { Agree } & \text { Agree } & \text { Disagree } \\
\text { Disagree }
\end{array}
$$

30. I will try harder to

introduce new people to

my friends and family at

the church.

$$
\text { Yes Often Maybe Never }
$$

31. This church meets

my needs.

$$
\begin{array}{lll}
\text { Strongly } & & \text { Strongly } \\
\text { Agree } & \text { Agree } & \text { Disagree } \\
\text { Disagree }
\end{array}
$$

32. I will do all I can to help

new members stay active in

our fellowship.

33. When this church has

$$
\text { Always Sometimes Seldom Never }
$$

evangelistic meetings,

I will attend.

$$
\text { Always Sometimes Seldom Never }
$$

34. This church is

just the right

size in membership.

$$
\begin{aligned}
& \text { Strongly Strongly } \\
& \text { Agree Agree Disagree Disagree }
\end{aligned}
$$

In the following set of questions, imagine yourself to be watching a new member [or interest] who has just begun to come to this church. They have children with them, and some are acting up, embarrassing them. other people in the church do not seem to be ignoring them. You are wondering what to do. Circle the answer that would represent your probable behavior after attending this seminar.

35. Would you go, introduce yourself to them and help them feel at home?

No Not sure Yes

36. Would you extend them an invitation to Sabbath dinner in your home?

No Not sure Yes

37. Would you introduce them to your friends and family?

No Not sure Yes 
38. Would you help them with

their children in church or in finding a Sabbath school program for their children?

No Not sure Yes

39. Would you try to be a friend?

No Not sure Yes

40. Would you invite them back to church next week?

No Not sure Yes 
THE COMBINED RESULTS OF THE THREE INITIAL SURVEYS

$$
\text { nonmem } 10+y r^{8} s \text { 6-10yrzs } 0 \text {-5yros } 8 \text { 's/total RAW }
$$

I have been a member of this local church for:

$\begin{array}{lccr}\text { la } & 0-1 \text { YEAR } & 3.48 & 3 \\ \text { Ib } & 1-5 \text { YRS } & 14.88 & 13 \\ \text { lc } & 6-10 \text { YRS } & 18.28 & 16 \\ \text { ld } & 10+\text { YRS } & 50.08 & 44 \\ \text { le } & \text { NONMEM } & 13.68 & 12\end{array}$

I am at the following age range:

$\begin{array}{lcccccrr}2 \mathrm{a} & <20 \text { YRS } & 1.0 & 0 & 0 & 1.0 & 2.38 & 2 \\ 2 \mathrm{~b} & 20-30 \text { YRS } & 2.0 & 5.0 & 1.0 & 4.0 & 13.88 & 12 \\ 2 \mathrm{c} & 31-50 \text { YRS } & 2.0 & 12.0 & 10.0 & 5.0 & 33.38 & 29 \\ 2 \mathrm{~d} & 51-65 \text { YRS } & 5.0 & 18.0 & 3.0 & 1.0 & 31.08 & 27 \\ 2 \mathrm{e} & 65+\text { YRS } & 2.0 & 9.0 & 2.0 & 4.0 & 19.58 & 17\end{array}$

I came to this church because:

$\begin{array}{lcllllll}3 \mathrm{a} & \text { BIO } & 1.0 & 9.0 & 1.0 & 3.0 & 16.38 & 14 \\ 3 \mathrm{~b} & \text { EVAN } & 3.0 & 7.0 & 1.0 & 2.0 & 15.18 & 13 \\ 3 \mathrm{c} & \text { BS } & 1.0 & 6.0 & 5.0 & 4.0 & 18.68 & 16 \\ 3 \mathrm{~d} & \text { OTH } & 7.0 & 22.0 & 8.0 & 6.0 & 50.08 & 43\end{array}$

I cherish this message/desire others to learn it

$$
\begin{array}{rccccrr}
4 \mathrm{Y} & 100.0 & 100.0 & 100.0 & 100.0 & 100.08 & 87 \\
4 \mathrm{~N} & 0 & 0 & 0 & 0 & 0.08 & 0
\end{array}
$$

God calling all to be SDA

$\begin{array}{lllllll}5 \mathrm{Y} & 63.6 & 65.9 & 62.5 & 68.8 & 65.58 & 57 \\ 5 \mathrm{~N} & 36.4 & 34.1 & 37.5 & 31.3 & 34.58 & 30\end{array}$

Church is to be a Hospital for sinners/rx everyone who comes.

$\begin{array}{rrrrrrr}6 \mathrm{Y} & 91.7 & 89.7 & 100.0 & 81.3 & 90.48 & 75 \\ 6 \mathrm{~N} & 8.3 & 10.3 & 0 & 18.8 & 9.68 & 8\end{array}$

My church has lots to offer this community.
$7 \mathrm{Y}$
91.7
81.4
62.5
87.5
80.58
70
$7 \mathrm{~N}$
$8.3 \quad 18.6$
37.5
$12.5 \quad 19.5$ 용
17

This church growing fast enough already.
$8 \mathrm{Y}$
$8 \mathrm{~N}$
100.0
4.7
12.5
$\begin{array}{cr}0 & 4.68 \\ 100.0 & 95.48\end{array}$
4
83

This church a warm and friendly place.
$9 Y$
$9 \mathrm{~N}$
81.8
83.3
75.0
$\begin{array}{rr}93.8 & 83.5 \% \\ 6.3 & 16.5 \%\end{array}$
71
14

$\begin{array}{lcccccc}\text { We know what God wants us to do locally as church in community. } & \\ \text { IOY } & 81.8 & 90.7 & 60.0 & 66.7 & 79.88 & 67 \\ \text { ION } & 18.2 & 9.3 & 40.0 & 33.3 & 20.2 \% & 17\end{array}$

Many people in this town need the fellowship this church can offer.
$11 Y$
$11 \mathrm{~N}$
91.7
95.3
81.3
93.391 .98
$6.7 \quad 8.18$
79 
nonmemis 10+yros 6-10yros 0-5yros 8 's/total

RAW

People need close

$12 \mathrm{Y}$

$12 \mathrm{~N}$

friends

$\begin{array}{cc}100.0 & 97.7 \\ 0 & 2.3\end{array}$

2.3

100.0

in the

church.

People of this church care about each other.

$$
13 Y
$$

$13 \mathrm{~N}$

72.7

27.3

80.5

19.5

75.0

25.0

87.5

12.5

$98.8 \%$

1.28

84

1

I have many friends in this church family.

$\begin{array}{lllllll}14 \mathrm{Y} & 58.3 & 77.3 & 81.3 & 81.3 & 76.18 & 67 \\ 14 \mathrm{~N} & 41.7 & 22.7 & 18.8 & 18.8 & 23.98 & 21\end{array}$

I am actively holding a church office this year.

$\begin{array}{rrrrrrr}15 Y & 8.3 & 69.8 & 87.5 & 37.5 & 58.68 & 51 \\ 15 \mathrm{~N} & 91.7 & 30.2 & 12.5 & 62.5 & 41.48 & 36\end{array}$

This church needs my help to succeed in its programs.
$16 Y$
60.0
66.7
87.5
71.4
70.78
58
$16 \mathrm{~N}$
40.0
33.3
12.5
28.6
29.38
24

$\mathrm{p}$

I believe this church should reach out\&bring in new mems from community.

$\begin{array}{lcccccr}17 Y & 100.0 & 100.0 & 100.0 & 93.8 & 98.98 & 87 \\ 17 \mathrm{~N} & 0 & 0 & 0 & 6.3 & 1.18 & 1 \\ \mathrm{p} & & & & & & \\ \text { It is easy for new comers to become part of this church family. } \\ \text { 18Y } & 72.7 & 58.5 & 50.0 & 73.3 & 61.48 & 51 \\ 18 \mathrm{~N} & 27.3 & 41.5 & 50.0 & 26.7 & 38.68 & 32\end{array}$

p

The restrooms are marked. That's all we need to do for visitors.

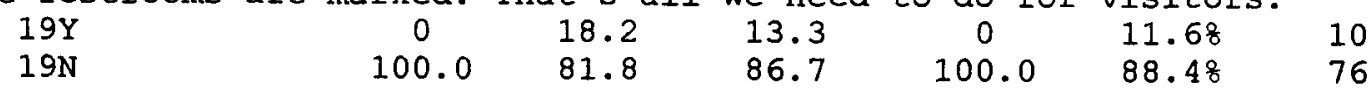

$\mathrm{p}$

We need a better outreach program in this church.
$20 Y$
90.9
9.1
100.0
93.8
100.0
$97.6 \%$
2.48
81
6.3
0
2.48
2

I would like to win souls for christ and would attend a training class.
$21 Y$
90.9
80.0
75. 0
53.3
$75.6 \%$
24.48
62
$21 \mathrm{~N}$
9.1
20.0
25.0
46.7
20

I am happy with the fellowship this church gives me.

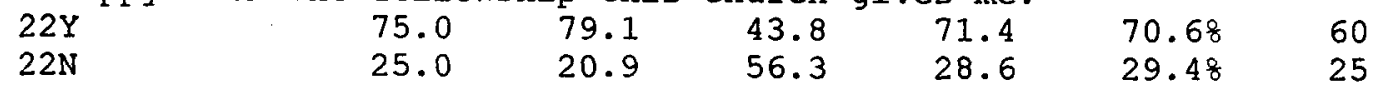

Evangelism is a job for pros, not lay people.
$23 \mathrm{Y}$
$23 \mathrm{~N}$
100.0
6.8
93.2
100.0
100.0
$3.5 \frac{8}{8}$
96.5 용
3

The pastor is the one we hire

$24 \mathrm{Y}$

0

6.8

$93.2 \quad 100.0$

100.0

100.0

NM, I'd ju

$\begin{array}{cc}\text { just get in way. } \\ 3.48 & 3 \\ 96.68 & 84\end{array}$

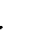
1 2 
nonmemss $10+y r^{8} s$ 6-10yr8s $0-5 y r 8 s$ o's/total. RAW

I believe in actively including $N M$ in what $I$ am doing in this church.

$\begin{array}{rcccrrr}25 \mathrm{Y} & 100.0 & 88.4 & 100.0 & 93.3 & 92.98 & 78 \\ 25 \mathrm{~N} & 0 & 11.6 & 0 & 6.7 & 7.18 & 6\end{array}$

This church is friendly to visitors and makes them feel at home.

$\begin{array}{llrrrrr}\text { 26NEVER } & 0 & 4.5 & 0 & 0 & 2.38 & 2 \\ \text { 26SELDOM } & 0 & 2.3 & 0 & 12.5 & 3.48 & 3 \\ \text { 26SOMETIMES } & 50.0 & 50.0 & 43.8 & 25.0 & 44.38 & 39 \\ \text { 26ALWAYS } & 50.0 & 43.2 & 56.3 & 62.5 & 50.08 & 44\end{array}$

I try to speak to $\mathrm{NM}$ and make them feel at home any way I can.

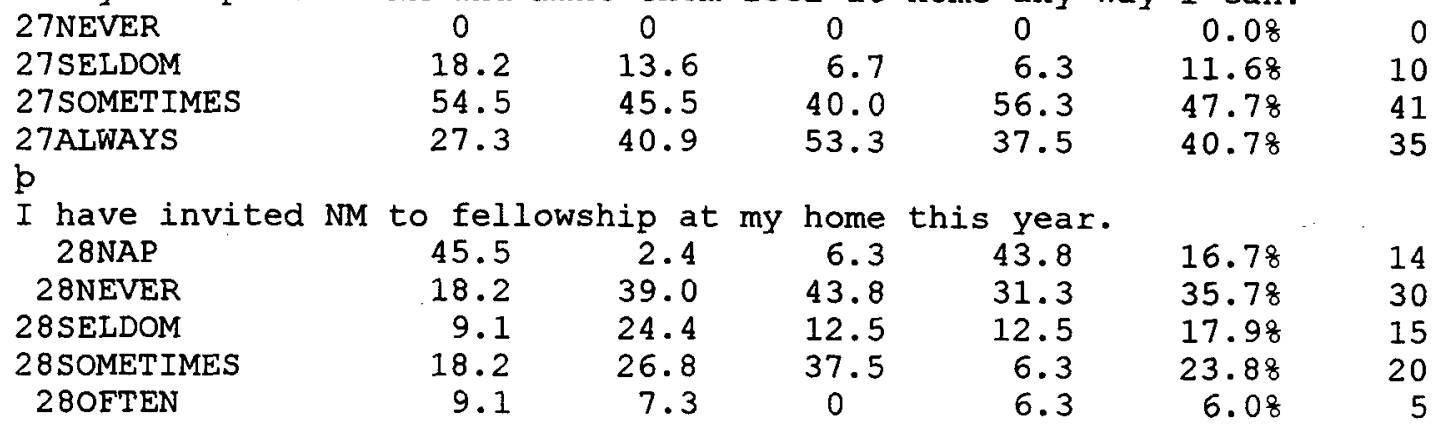

The church does NM a disservice when it "coddles" them.

$\begin{array}{rrrrrrr}29 S A & 9.1 & 5.1 & 6.3 & 0 & 4.98 & 4 \\ 29 A & 27.3 & 17.9 & 12.5 & 26.7 & 19.88 & 16 \\ 29 D & 36.4 & 61.5 & 56.3 & 66.7 & 58.08 & 47 \\ 29 S D & 27.3 & 15.4 & 25.0 & 6.7 & 17.38 & 14\end{array}$

I try to introduce new people to my other friends at the church.

$\begin{array}{lrrrrrr}\text { 30ALWAYS } & 36.4 & 16.7 & 26.7 & 18.8 & 21.48 & 18 \\ \text { 30SOMETHIMES } & 36.4 & 61.9 & 46.7 & 68.8 & 57.18 & 48 \\ \text { 3OSELDOM } & 9.1 & 16.7 & 20.0 & 6.3 & 14.38 & 12 \\ \text { 3ONEVER } & 18.2 & 4.8 & 6.7 & 6.3 & 7.18 & 6\end{array}$

This church meets my needs.

$\begin{array}{rrrrrrr}\text { 31SA } & 0 & 11.4 & 6.3 & 23.5 & 11.28 & 10 \\ 31 \mathrm{~A} & 66.7 & 68.2 & 68.8 & 58.8 & 66.38 & 59 \\ 31 \mathrm{D} & 16.7 & 18.2 & 25.0 & 11.8 & 18.08 & 16 \\ 31 \mathrm{SD} & 16.7 & 2.3 & 0 & 5.9 & 4.58 & 4\end{array}$

New members who join this church stay active in its fellowship.

$\begin{array}{lcrrrrr}\text { 32ALWAYS } & 0 & 2.3 & 6.3 & 13.3 & 4.78 & 4 \\ \text { 32SOMETIMES } & 81.8 & 86.4 & 81.3 & 60.0 & 80.28 & 69 \\ \text { 32SELDOM } & 18.2 & 9.1 & 6.3 & 26.7 & 12.88 & 11 \\ \text { 32NEVER } & 0 & 2.3 & 6.3 & 0 & 2.38 & 2\end{array}$

When this church has evangelistic meetings I attend.

$\begin{array}{lrrrrrr}\text { 33ALWAYS } & 18.2 & 22.7 & 28.6 & 37.5 & 25.98 & 22 \\ \text { 33SOMETIMES } & 63.6 & 63.6 & 57.1 & 25.0 & 55.38 & 47 \\ \text { 33SELDOM } & 9.1 & 13.6 & 14.3 & 25.0 & 15.38 & 13 \\ \text { 33NEVER } & 9.1 & 0 & 0 & 12.5 & 3.58 & 3\end{array}$


nonmemis 10+yris 6-10yris 0-5yrzs o's/total RAW

This church is just the right size in membership.

$\begin{array}{lcccccr}34 \mathrm{SA} & 0 & 2.3 & 6.3 & 0 & 2.38 & 2 \\ 34 \mathrm{~A} & 0 & 11.4 & 0 & 0 & 5.78 & 5 \\ 34 \mathrm{D} & 41.7 & 65.9 & 62.5 & 73.3 & 63.28 & 55 \\ 34 \mathrm{SD} & 58.3 & 20.5 & 31.3 & 26.7 & 28.78 & 25\end{array}$

Would most people receive you with a smile and help you feel at home?

$\begin{array}{lcccccr}35 \mathrm{~N} & 0 & 6.8 & 0 & 0 & 3.48 & 3 \\ 35 \mathrm{NS} & 8.3 & 15.9 & 12.5 & 18.8 & 14.88 & 13 \\ 35 \mathrm{Y} & 91.7 & 77.3 & 87.5 & 81.3 & 81.88 & 72\end{array}$

Would you $r x$ an invitation to Sabbath dinner in someone's home?

$\begin{array}{lcccccc}36 \mathrm{~N} & 16.7 & 18.2 & 6.3 & 18.8 & 15.98 & 14 \\ 36 \mathrm{NS} & 41.7 & 40.9 & 37.5 & 37.5 & 39.88 & 35 \\ 36 \mathrm{Y} & 41.7 & 40.9 & 56.3 & 43.8 & 44.38 & 39\end{array}$

Would people come up and introduce themselves?

$\begin{array}{lrrrrrr}37 \mathrm{~N} & 8.3 & 11.6 & 0 & 6.7 & 8.48 & 7 \\ 37 \mathrm{NS} & 8.3 & 14.0 & 7.7 & 26.7 & 14.58 & 12 \\ 37 \mathrm{Y} & 83.3 & 74.4 & 92.3 & 66.7 & 77.18 & 64\end{array}$

Would your children have a Sabbath school program?

$\begin{array}{lrrrrrr}38 \mathrm{~N} & 25.0 & 11.4 & 12.5 & 15.4 & 14.18 & 12 \\ 38 \mathrm{NS} & 8.3 & 13.6 & 12.5 & 0 & 10.68 & 9 \\ 38 \mathrm{Y} & 66.7 & 75.0 & 75.0 & 84.6 & 75.38 & 64\end{array}$

Would you leave feeling you had made new friends?

$\begin{array}{lrrrrrr}39 \mathrm{~N} & 8.3 & 4.7 & 6.3 & 12.5 & 6.98 & 6 \\ 39 \mathrm{NS} & 8.3 & 20.9 & 25.0 & 12.5 & 18.48 & 16 \\ 39 \mathrm{Y} & 83.3 & 74.4 & 68.8 & 75.0 & 74.78 & 65\end{array}$

Would you come back next week?

$\begin{array}{lrrrrrr}4 \text { ON } & 0 & 4.5 & 0 & 0 & 2.38 & 2 \\ 40 \mathrm{NS} & 16.7 & 13.6 & 12.5 & 25.0 & 15.98 & 14 \\ 40 \mathrm{Y} & 83.3 & 81.8 & 87.5 & 75.0 & 81.88 & 72\end{array}$


nonmemos 10tyros 6-10yros 0-5yros o's/totalRAW

I have been a member of this local church for:

$$
\begin{array}{ll}
\text { la } & 0-1 \text { YEAR } \\
\text { 1b } & 1-5 \text { YRS } \\
\text { lc } & 6-10 \text { YRS } \\
\text { ld } & 10+\text { YRS } \\
\text { le } & \text { NONMEM }
\end{array}
$$

$\begin{array}{rr}12.88 & 5 \\ 23.18 & 9 \\ 15.48 & 6 \\ 41.08 & 16 \\ 7.78 & 3\end{array}$

I am at the following age range:

$\begin{array}{llllllrr}2 \mathrm{a} & <20 \text { YRS } & 0 & 0 & 0 & 0 & 0.08 & 0 \\ 2 \mathrm{~b} & 20-30 \text { YRS } & 0 & 0 & 0 & 2 & 5.18 & 2 \\ 2 \mathrm{C} & 31-50 \text { YRS } & 0 & 5 & 5 & 8 & 46.28 & 18 \\ 2 \mathrm{~d} & 51-65 \text { YRS } & 2 & 4 & 1 & 2 & 23.18 & 9 \\ 2 \mathrm{e} & 65+\text { YRS } & 1 & 7 & 0 & 2 & 25.68 & 10\end{array}$

I came to this church bacause:

$\begin{array}{lllrrrrr}3 a & \text { BIO } & 0 & 5 & 2 & 1 & 20.58 & 8 \\ 3 \mathrm{~b} & \text { EVAN } & 0 & 0 & 0 & 0 & 0.08 & 0 \\ 3 \mathrm{c} & \text { BS } & 1 & 1 & 0 & 2 & 10.38 & 4 \\ 3 \mathrm{~d} & \text { OTH } & 2 & 10 & 4 & 11 & 69.28 & 27\end{array}$

I cherish this message/desire others to learn it

$\begin{array}{rrrrrrr}4 \mathrm{Y} & 100 & 100 & 100 & 100 & 100.08 & 38 \\ 4 \mathrm{~N} & 0 & 0 & 0 & 0 & 0.08 & 0\end{array}$

God calling all to be SDA

$\begin{array}{rrrrrrr}5 \mathrm{Y} & 100 & 67 & 50 & 79 & 70.38 & 26 \\ 5 \mathrm{~N} & 0 & 33 & 50 & 21 & 29.78 & 11\end{array}$

Church is to be a Hospital for sinners/rx everyone who comes.

$\begin{array}{rrrrrrr}6 \mathrm{Y} & 50 & 87 & 100 & 85 & 86.18 & 31 \\ 6 \mathrm{~N} & 50 & 13 & 0 & 15 & 13.98 & 5\end{array}$

My church has lots to offer this community.

$\begin{array}{rrrrrrr}7 \mathrm{Y} & 100 & 94 & 100 & 86 & 92.38 & 36 \\ 7 \mathrm{~N} & 0 & 6 & 0 & 14 & 7.78 & 3\end{array}$

This church growing fast enough already.

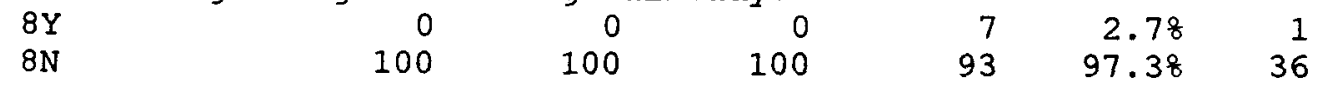

This church a warm and friendly place.

$\begin{array}{rrrrrrr}9 \mathrm{Y} & 100 & 93 & 67 & 86 & 86.88 & 33 \\ 9 \mathrm{~N} & 0 & 7 & 33 & 14 & 13.28 & 5\end{array}$

We know what God wants us to do locally as church in community. $\begin{array}{rrrrrrr}10 Y & 100 & 88 & 17 & 100 & 81.68 & 31 \\ 10 \mathrm{~N} & 0 & 13 & 83 & 0 & 18.48 & 7\end{array}$

Many people in this town need the fellowship this church can offer. $\begin{array}{rrrrrrr}11 Y & 100 & 100 & 100 & 93 & 97.48 & 38 \\ 11 \mathrm{~N} & 0 & 0 & 0 & 7 & 2.68 & 1\end{array}$

People need close friends who care about them in the church. $\begin{array}{rrrrrrr}12 \mathrm{Y} & 100 & 100 & 100 & 100 & 100.08 & 39 \\ 12 \mathrm{~N} & 0 & 0 & 0 & 0 & 0.08 & 0\end{array}$ 


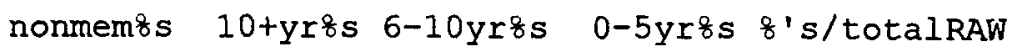

People of this church care about each other.

$\begin{array}{rrrrrrr}13 Y & 100 & 87 & 100 & 85 & 89.28 & 33 \\ 13 \mathrm{~N} & 0 & 13 & 0 & 15 & 10.88 & 4\end{array}$

I have many friends in this church family.

$\begin{array}{lrrrrrr}14 \mathrm{Y} & 100 & 88 & 83 & 50 & 74.48 & 29 \\ 14 \mathrm{~N} & 0 & 13 & 17 & 50 & 25.68 & 10\end{array}$

I am actively holding a church office this year.

$\begin{array}{lrlllll}15 \mathrm{Y} & 0 & 88 & 67 & 57 & 66.78 & 26 \\ 15 \mathrm{~N} & 100 & 13 & 33 & 43 & 33.38 & 13\end{array}$

This church needs my help to succeed in its programs.
$16 Y$
$16 \mathrm{~N}$
100
79
83
93
89.18
10.98
41

I believe this ch should reach outdbring in new mems from community.
$17 Y$
100
100
100
93
97.48
2.68

It is easy for new commers to become part of this church family.
$18 \mathrm{Y}$
$18 \mathrm{~N}$
$\begin{array}{ll}50 & 75 \\ 50 & 25\end{array}$
50
$\begin{array}{lll}77 & 70.38 & 26\end{array}$
$23 \quad 29.78 \quad 11$

The restrooms are marked. That's all we need to do for visitors.
$19 Y$
$19 \mathrm{~N}$
33
19
81
100
100
10.38
$89.78 \quad 35$

We need a better outreach program in this church.
$20 \mathrm{Y}$
$20 \mathrm{~N}$
100
100
100
100
$100.08 \quad 38$
$0.08 \quad 0$

I would like to win souls for Christ and would attend a training class.
$21 Y$
$21 \mathrm{~N}$
100
100
0
83
17
100
97.18
2.98
34
0
1

I am happy with the fellowship this church gives me.
$22 \mathrm{Y}$
$22 \mathrm{~N}$
100
81
50
64
71.88
28
36
11

Evangelism is a job for pros, not lay people.
$23 Y$
$23 \mathrm{~N}$
100
100
100
$0 \quad 0.08$
0
38

The pastor is the one we hire to take care of NM, I'd just get in way.
$24 \mathrm{Y}$
0
$24 \mathrm{~N}$
100
100
100
$\begin{array}{lll}100 \quad 100.08 & 38\end{array}$

I believe in actively including $N M$ in what $I$ am doing in this church.
$25 Y$
$25 \mathrm{~N}$
100
0
100
100
100
100.08
$0.08 \quad 0$

This church is friendly to visitors and makes them feel at home.

26NEVER

26SELDOM

26SOMETIMES

26ALWAYS

$\begin{array}{rr}0 & 6 \\ 0 & 0 \\ 67 & 50 \\ 33 & 44\end{array}$

6
0
50
44

4

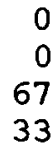

0
07
33

$\begin{array}{rrr}0 & 2.68 & 1 \\ 7 & 2.68 & 1 \\ 36 & 48.78 & 19 \\ 57 & 46.28 & 18\end{array}$


nonmemos $10+y r 8 s \quad 6-10 y r 8 s$ 0-5yros 8's/totalRAW

I will try hardr to speak to NM and make them feel at home any way I can

$27 \mathrm{NO}$

27SOME

27OFTEN

27ALWAYS

$\begin{array}{rr}0 & 0 \\ 0 & 6 \\ 33 & 19 \\ 67 & 75\end{array}$

75

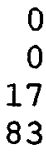

0
17
83
0.08

2.68

20.58

76.98

1
8
30

I will be inviting NM to fellowship at my home this year.

$\begin{array}{lrrrrrr}28 \mathrm{NAP} & 33 & 14 & 0 & 7 & 10.88 & 4 \\ 28 \mathrm{SA} & 0 & 14 & 33 & 21 & 18.98 & 7 \\ 28 \mathrm{~A} & 67 & 71 & 50 & 64 & 64.98 & 24 \\ 28 \mathrm{D} & 0 & 0 & 17 & 7 & 5.48 & 2 \\ 28 \mathrm{SD} & 0 & 0 & 0 & 0 & 0.08 & 0\end{array}$

The church does NM a disservice when it "coddles" them.

$\begin{array}{rrrrrrr}29 S A & 0 & 0 & 0 & 7 & 2.68 & 1 \\ 29 A & 0 & 25 & 0 & 14 & 15.88 & 6 \\ 29 D & 50 & 44 & 67 & 57 & 52.68 & 20 \\ 29 S D & 50 & 31 & 33 & 21 & 28.98 & 11\end{array}$

I will try harder to introduce new people to my f\&f at the church.

$\begin{array}{lrrrrrr}\text { 30YES } & 67 & 81 & 67 & 93 & 82.18 & 32 \\ \text { 30OFTEN } & 33 & 13 & 17 & 7 & 12.88 & 5 \\ \text { 30MAYBE } & 0 & 6 & 17 & 0 & 5.18 & 2 \\ \text { 3ONEVER } & 0 & 0 & 0 & 0 & 0.08 & 0\end{array}$

This church meets my needs.

$\begin{array}{rrrrrrr}\text { 31SA } & 0 & 13 & 0 & 21 & 12.88 & 5 \\ 31 \mathrm{~A} & 100 & 75 & 67 & 43 & 64.18 & 25 \\ 31 \mathrm{D} & 0 & 6 & 33 & 29 & 17.98 & 7 \\ 31 \mathrm{SD} & 0 & 6 & 0 & 7 & 5.18 & 2\end{array}$

I will do all I can to help NM stay active in our fellowship.

$\begin{array}{lrrrrrr}\text { 32ALWAYS } & 100 & 81 & 67 & 93 & 84.28 & 32 \\ \text { 32SOMETIMES } & 0 & 19 & 33 & 7 & 15.88 & 6 \\ \text { 32SELDOM } & 0 & 0 & 0 & 0 & 0.08 & 0 \\ \text { 32NEVER } & 0 & 0 & 0 & 0 & 0.08 & 0\end{array}$

When this church has evangelistic meetings I will attend.

$\begin{array}{lrrrrrr}\text { 33ALWAYS } & 33 & 50 & 17 & 71 & 51.38 & 20 \\ \text { 33SOMETIMES } & 67 & 44 & 83 & 29 & 46.28 & 18 \\ \text { 33SELDOM } & 0 & 6 & 0 & 0 & 2.68 & 1 \\ \text { 33NEVER } & 0 & 0 & 0 & 0 & 0.08 & 0\end{array}$

This church is just the right size in membership.

$\begin{array}{rrrrrrr}34 \mathrm{SA} & 0 & 0 & 0 & 7 & 2.68 & 1 \\ 34 \mathrm{~A} & 33 & 0 & 17 & 7 & 7.78 & 3 \\ 34 \mathrm{D} & 0 & 75 & 33 & 36 & 48.78 & 19 \\ 34 \mathrm{SD} & 67 & 25 & 50 & 50 & 41.08 & 16\end{array}$

Would you go, introduce yourself to them and help them feel at home?

$\begin{array}{rrrrrrr}35 \mathrm{~N} & 0 & 0 & 0 & 0 & 0.08 & 0 \\ 35 \mathrm{NS} & 67 & 14 & 17 & 21 & 21.68 & 8 \\ 35 \mathrm{Y} & 33 & 86 & 83 & 79 & 78.48 & 29\end{array}$


nonmemss 10+yrzs 6-10yros 0-5yros \&'s/totalRAw

Would you extend them an invitation to Sabbath dinner in your home?

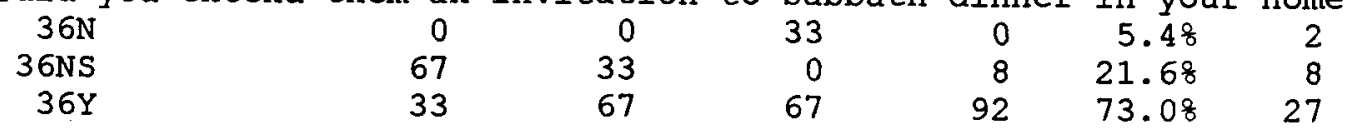

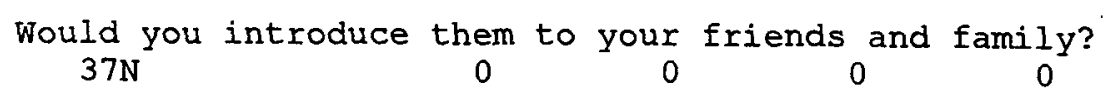

$37 \mathrm{NS}$

$37 Y$

33

67

17

83

0
7
93

0.08

7.98

92.18

0
3
35

Would you

$38 \mathrm{NS}$

$38 \mathrm{Y}$

$\begin{array}{ccc}\text { with } & \text { their children in } \\ 0 & 0 & 0 \\ 100 & 13 & 33 \\ 0 & 87 & 67\end{array}$

church

or in finding a
0.08

sS pgm

67

100

16.28

6

$83.8 \%$

31

Would you try to be a friend?

$\begin{array}{rrrrrrr}39 \mathrm{~N} & 0 & 0 & 0 & 0 & 0.08 & 0 \\ 39 \mathrm{NS} & 0 & 0 & 0 & 0 & 0.08 & 0 \\ 39 \mathrm{Y} & 100 & 100 & 100 & 100 & 100.08 & 38\end{array}$

Would you invite them back to church next week?

$\begin{array}{rrrrrrr}40 \mathrm{~N} & 0 & 0 & 0 & 0 & 0.08 & 0 \\ 4 \mathrm{NS} & 0 & 0 & 0 & 0 & 0.08 & 0 \\ 40 \mathrm{Y} & 100 & 100 & 100 & 100 & 100.08 & 38\end{array}$


COMBINED RESULTS OF FOLLOW UP SURVEY ONLY FOR THOSEP WHO FILLED OUT THE INITIAL QUESTIONNAIREP

nonmemzs $10+y r z s$ 6-10yros $0-5 y r 8 s$ s's/total RAW

I have been a member of this local church for:
la $0-1$ YEAR
$1 b \quad 1-5$ YRS
4.58
27.38
1c 6-10 YRS
13.68
1d $10+$ YRS
45.58
NONMEM
9.18
1
6
3
10
2

I am at the following age range:

$\begin{array}{lllllllr}2 \mathrm{a} & <20 \text { YRS } & 0 & 0 & 0 & 0 & 0.08 & 0 \\ 2 \mathrm{~b} & 20-30 \text { YRS } & 0 & 0 & 0 & 1 & 4.58 & 1 \\ 2 \mathrm{c} & 31-50 \text { YRS } & 0 & 4 & 2 & 4 & 45.58 & 10 \\ 2 \mathrm{~d} & 51-65 \text { YRS } & 2 & 3 & 1 & 0 & 27.38 & 6 \\ 2 \mathrm{e} & 65+\text { YRS } & 0 & 3 & 0 & 2 & 22.78 & 5\end{array}$

I came to this church bacause:

$\begin{array}{llllllrr}3 \mathrm{a} & \text { BIO } & 0 & 2 & 0 & 1 & 13.68 & 3 \\ 3 \mathrm{~b} & \text { EVAN } & 0 & 0 & 0 & 0 & 0.08 & 0 \\ 3 \mathrm{c} & \text { BS } & 0 & 1 & 0 & 1 & 9.18 & 2 \\ 3 \mathrm{~d} & \text { OTH } & 2 & 7 & 3 & 5 & 77.38 & 17\end{array}$

I cherish this message/desire others to learn it

$\begin{array}{rrrrrrr}4 \mathrm{Y} & 100 & 100 & 100 & 100 & 100.08 & 21 \\ 4 \mathrm{~N} & 0 & 0 & 0 & 0 & 0.08 & 0\end{array}$

God calling all to be SDA

$\begin{array}{rrrrrrr}5 \mathrm{Y} & 100 & 67 & 0 & 86 & 65.08 & 13 \\ 5 \mathrm{~N} & 0 & 33 & 100 & 14 & 35.08 & 7\end{array}$

Church is to be a Hospital for sinners/rx everyone who comes.

$\begin{array}{rrrrrrr}6 \mathrm{Y} & 50 & 90 & 100 & 100 & 90.98 & 20 \\ 6 \mathrm{~N} & 50 & 10 & 0 & 0 & 9.18 & 2\end{array}$

My church has lots to offer this community.

$\begin{array}{ccccccc}7 \mathrm{Y} & 100 & 90 & 100 & 86 & 90.98 & 20 \mathrm{~b} \\ 7 \mathrm{~N} & 0 & 10 & 0 & 14 & 9.18 & 2 \mathrm{p}\end{array}$

This church growing fast enough already.

$\begin{array}{rrrrrrr}8 Y & 0 & 0 & 0 & 14 & 4.58 & 1 \\ 8 \mathrm{~N} & 100 & 100 & 100 & 86 & 95.58 & 21\end{array}$

This church a warm and friendly place.
$9 \mathrm{Y}$
100
$90 \quad 67$
100
90.98
9.18
20
$9 \mathrm{~N}$
1033

0

9.18

We know what God wants us to do locally as church in community.

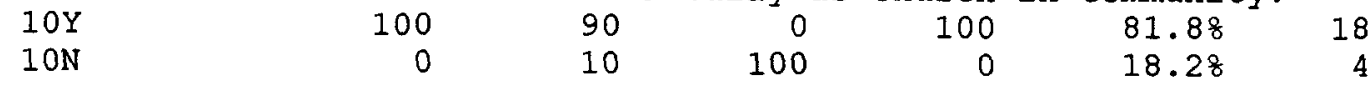

Many people in this town need the fellowship this church can offer. $\begin{array}{rrrrrrr}11 Y & 100 & 100 & 100 & 100 & 100.08 & 22 \\ 11 \mathrm{~N} & 0 & 0 & 0 & 0 & 0.08 & 0\end{array}$ 
nonmem8s $10+y r 8 s \quad 6-10 y r 8 s \quad 0-5 y r 8 s \quad 8$ 's/total

RAW

People need close friends who care about them in the church.

$12 Y$

$12 \mathrm{~N}$
100

0

$$
100
$$

0
100
0

$$
100
$$

0

$$
100.08
$$

0.08
95.28

4.88

4.88
22

0

People of this church care about each other.

$13 Y$

$13 \mathrm{~N}$

89

100

0

100

20

1

I have many friends in this church family.
$14 Y$
$14 \mathrm{~N}$
100
0
$90 \quad 100$
86
14
90.98
9.18
20
2
I am actively holding a church office this year.

$\begin{array}{rrrrrrr}15 \mathrm{Y} & 0 & 80 & 100 & 57 & 68.28 & 15 \\ 15 \mathrm{~N} & 100 & 20 & 0 & 43 & 31.88 & 7\end{array}$

This church needs my help to succeed in its programs.
$16 \mathrm{Y}$
$16 \mathrm{~N}$
100
70
100
100
90.68
9.48
29
3

I believe this ch should reach out\&bring in new mems from community.
$17 Y$
$17 \mathrm{~N}$
100
100
100
100
100.08
0.08
22

It is easy for new commers to become part of this church family. $\begin{array}{llllrrr}18 \mathrm{Y} & 50 & 80 & 67 & 100 & 81.88 & 18 \\ 18 \mathrm{~N} & 50 & 20 & 33 & 0 & 18.28 & 4\end{array}$

The restrooms are marked. That's all we need to do for visitors.
$19 Y$
$19 \mathrm{~N}$
100
20
100
100
$9.1 \frac{1}{8}$
90.98
2
100
gram in this church.
$20 \mathrm{~N}$
100
100
100
100.08
0.08
22

We need
$20 Y$

$\begin{array}{ccccccc}\text { I would like to win souls for Christ and would attend a training class. } \\ 21 Y & 100 & 100 & 67 & 100 & 95.28 & 20\end{array}$
$21 \mathrm{~N}$
33
4.88
1

I am happy with the fellowship this church gives me.
$22 Y$
$22 \mathrm{~N}$
100
80
20
33
86
1422.78
$\begin{array}{rr}77.38 & 17 \\ 22.78 & 5\end{array}$

Evangelism is a job for pros, not lay people.
$23 Y$
$23 N$
$\begin{array}{rr}0 & 0 \\ 100 & 100\end{array}$
100
100
0.08
100.08
0
22

The pastor is the one we hire to take care of NM, I'd just get in way.
$24 Y$
$24 \mathrm{~N}$
100
100
100
100
0.0 웅
100.08
22

I believe in actively including $N M$ in what $I$ am doing in this church.

$25 Y$

$25 \mathrm{~N}$

100

100

100

100

100.08

0.08

22 
nonmemss $10+y r^{8} s \quad 6-10 y r 8 s \quad 0-5 y r^{8} s$ 8's/total

RAW

This church is friendly to visitors and makes them feel at home.

$\begin{array}{lrrrrrr}\text { 26NEVER } & 0 & 0 & 0 & 0 & 0.08 & 0 \\ \text { 26SELDOM } & 0 & 0 & 0 & 0 & 0.08 & 0 \\ \text { 26SOMETIMES } & 50 & 60 & 67 & 43 & 54.58 & 12 \\ \text { 26ALWAYS } & 50 & 40 & 33 & 57 & 45.58 & 10\end{array}$

I will try hardr to speak to NM and make them feel at home any way I can $27 \mathrm{NO}$ 27SOME

27OFTEN

$\begin{array}{rr}0 & 0 \\ 0 & 0 \\ 50 & 30 \\ 50 & 70\end{array}$

$\begin{array}{rr}0 & \\ 0 & 14 \\ 100 & 86\end{array}$

0
14
86

0.08

0.08

22.78

77.38

0

27ALWAYS

100

86

5

I will be inviting NM to fellowship at my home this year.

$\begin{array}{lrrrrrr}28 \mathrm{NAP} & 0 & 25 & 0 & 0 & 10.08 & 2 \\ 28 \mathrm{SA} & 0 & 13 & 33 & 14 & 15.08 & 3 \\ 28 \mathrm{~A} & 100 & 63 & 67 & 71 & 70.08 & 14 \\ 28 \mathrm{D} & 0 & 0 & 0 & 14 & 5.08 & 1 \\ 28 \mathrm{SD} & 0 & 0 & 0 & 0 & 0.08 & 0\end{array}$

The church does NM a disservice when it "coddles" them.

$\begin{array}{lrrrrrr}29 \mathrm{SA} & 0 & 0 & 0 & 14 & 4.58 & 1 \\ 29 \mathrm{~A} & 0 & 20 & 0 & 14 & 13.68 & 3 \\ 29 \mathrm{D} & 50 & 50 & 100 & 57 & 59.18 & 13 \\ 29 \mathrm{SD} & 50 & 30 & 0 & 14 & 22.78 & 5\end{array}$

I will try harder to introduce new people to my f\&f at the church.

$\begin{array}{lrrrrrr}\text { 30YES } & 50 & 70 & 100 & 86 & 77.38 & 17 \\ \text { 30OFTEN } & 50 & 20 & 0 & 14 & 18.28 & 4 \\ \text { 3OMAYBE } & 0 & 10 & 0 & 0 & 4.58 & 1 \\ \text { 30NEVER } & 0 & 0 & 0 & 0 & 0.08 & 0\end{array}$

This church meets my needs.

$\begin{array}{lrrrrrr}31 \mathrm{SA} & 0 & 0 & 0 & 43 & 13.68 & 3 \\ 31 \mathrm{~A} & 100 & 80 & 67 & 43 & 68.28 & 15 \\ 31 \mathrm{D} & 0 & 10 & 33 & 14 & 13.68 & 3 \\ 31 \mathrm{SD} & 0 & 10 & 0 & 0 & 4.58 & 1\end{array}$

I will do all I can to help NM stay active in our fellowship.

$\begin{array}{lrrrrrr}\text { 32ALWAYS } & 100 & 70 & 100 & 86 & 81.88 & 18 \\ \text { 32SOMETIMES } & 0 & 30 & 0 & 14 & 18.28 & 4 \\ \text { 32SELDOM } & 0 & 0 & 0 & 0 & 0.08 & 0 \\ \text { 32NEVER } & 0 & 0 & 0 & 0 & 0.08 & 0\end{array}$

When this church has evangelistic meetings I will attend.

$\begin{array}{lrrrrrr}\text { 33ALWAYS } & 50 & 50 & 33 & 86 & 59.18 & 13 \\ \text { 33SOMETIMES } & 50 & 40 & 67 & 14 & 36.48 & 8 \\ \text { 33NEVER } & 0 & 0 & 0 & 0 & 0.08 & 0\end{array}$

This church is just the right size in membership.

$\begin{array}{lrrrrrr}34 \mathrm{SA} & 0 & 0 & 0 & 14 & 4.58 & 1 \\ 34 \mathrm{~A} & 0 & 0 & 0 & 14 & 4.58 & 1 \\ 34 \mathrm{D} & 0 & 70 & 67 & 43 & 54.58 & 12 \\ 34 \mathrm{SD} & 100 & 30 & 33 & 29 & 36.48 & 8\end{array}$

Would you go, introduce yourself to them and help them feel at home?

$\begin{array}{lrrrrrr}35 \mathrm{~N} & 0 & 0 & 0 & 0 & 0.08 & 0 \\ 35 \mathrm{NS} & 100 & 11 & 33 & 14 & 23.88 & 5 \\ 35 \mathrm{Y} & 0 & 89 & 67 & 86 & 76.28 & 16\end{array}$


nonmemss 10+yros 6-10yros 0-5yrzs o's/total RAW

Would you extend them an invitation to Sabbath dinner in your home?

$\begin{array}{lrrrrrr}36 \mathrm{~N} & 0 & 0 & 33 & 0 & 4.58 & 1 \\ 36 \mathrm{NS} & 100 & 40 & 0 & 14 & 31.88 & 7 \\ 36 \mathrm{Y} & 0 & 60 & 67 & 86 & 63.68 & 14\end{array}$

Would you introduce them to your friends and family?

$37 \mathrm{~N}$

$37 \mathrm{NS}$

$37 Y$
0

100

$\begin{array}{rr}0 & 0 \\ 0 & 0 \\ 100 & 100\end{array}$

0
0
100

0.08
0.08

100.08

0
0

22

$\begin{array}{lcccccc}\text { Would you help them with their children in church or in finding a sS pgm } \\ \text { 38N } & 0 & 0 & 0 & 0 & 0.08 & 0 \\ \text { 38NS } & 100 & 10 & 33 & 0 & 18.28 & 4 \\ \text { 38Y } & 0 & 90 & 67 & 100 & 81.88 & 18\end{array}$

Would you try to be a friend?

$\begin{array}{lrrrrrr}39 \mathrm{~N} & 0 & 0 & 0 & 0 & 0.08 & 0 \\ 39 \mathrm{NS} & 0 & 0 & 0 & 0 & 0.08 & 0 \\ 39 \mathrm{Y} & 100 & 100 & 100 & 100 & 100.08 & 22\end{array}$

Would you invite them back to church next week?

$40 \mathrm{~N}$

4 ONS

$4 O Y$
0
0
100

100

0
0
100

0

100

next
0
0
100

0
0
100

100
0.08

0.08

100.08

\section{7}


Pastoral Interview

The results by question:

1) How long have you been in the ministry?

Pastor 1) 3 years

Pastor 2) 14 years

Pastor 3) 16 years

2) How long have you been in this district?

Pastor 1) 11 months

Pastor 2) $21 / 2$ years

Pastor 3) 7 years

3) How many churches do you pastor now?

$\begin{array}{lll}\text { Pastor 1) } & 2 \text { churches } \\ \text { Pastor 2) } & 2 \text { churches } \\ \text { Pastor 3) } & 2 \text { churches }\end{array}$

4) What are your church's sizes in terms of active membership? What is the median age of your congregation's established members?

Pastor 1) Church 1 has 50 active members out of 80 book members, median age 48 .

Church 2 has 35 active members out of 80 book members, median age 55 .

Pastor 2) Church 1 is over 100 active members and not in survey Church 2 has 50 active members out of 93 book members, median age 39 .

Pastor 3) Church 1 has 40 active members out of 81 book members, median age 45 .

Church 2 has 40 active members out of 62 book members, median age 37 .

5) Would you say your church functions as a

$\underline{\text { Pastor } 1} \quad$ Pastor $2 \quad$ Pastor 3

a) Family cell-group?

b) Pastoral Church? Both pastoral

Family Cell Both Family

6) Who are the leaders of your congregations? The Patriarch's and Matriarch's. Are they well defined?

\section{Church 1}

Pastor 1) No Real Patriarch/matriarch

Pastor 2) No well defined Patriarch/Mat

Pastor 3) Well defined Pat./mat.
Church 2

Patriarch/matriarch not well defined

Well defined pat./mat. 
Pastor's Survey Results - continued

7) Describe the established groups in your congregation. How many of them are open to receiving new people into their numbers? How many are closed?

\section{Church 1}

Pastor 1) One group (open)

Pastor 2) Five groups ( 3 Fam-Closed; 2 study-Open)

Pastor 3) Four grps (2 Sab Sch - Open

1 Family - Open

1 Small Grp- Open

\section{Church 2}

Three groups (closed)

Two groups (Healthy grp

-Closed

Family group -Closed)

8) Are there many openings into your inner church fellowship?

What are the primary ones from your point of view?

\section{Church 1}

Pastor 1)

Pastor 2)

Pastor 31 one opening: leadership grp

only one opening

one opening (screening pres.)
Church 2

No openings

One opening - Social

9) Do your churches receive many visitors from the community who could decide to attend regularly? How do you encourage visitors to return?

Pastor 1) 3 to 5 visitors/wk - No formal welcoming mechanism.

Pastor 2) Few visitors - No mechanism for welcoming

Pastor 3) No visitors - No mechanisms to welcome them.

10) If new people show up for worship on Sabbath, what usually happens for them?

Pastor 1) Wecome at the door, directions to classes - nothing formal, but has plans to institute something for 1995.

Pastor 2) The members will greet them a few times, informally, nothing more.

Pastor 3) People may be invited home - but no follow up and they may not enjoy the screening experience in the home.

11) If you were coming to church for the first time as a

Seventh-day Adventist, and you came to your church, what about that church would impress you the most?

Pastor 1) Doesn't know

Pastor 2) Friendly people - nicely kept building

Pastor 3) A few hospitable members but not too pleasant (in one church)

Would feel more at home in the second church.

12) What experience do you think you would have on that first visit? Would you be likely to return?

Pastor 1) $50 / 50$ chance of return.

Pastor 2) "I would not feel a burden to go elsewhere."

Pastor 3) Return to church 1 would be "iffy;"

but return to church two is more likely. 
Pastor's Survey Results - continued

13) What are the reasons you think many who come into our churches through baptism and profession of faith leave active membership within a year or two?

Pastor 1) Decrease in attention given to new members after baptism,

Not finding friends in the church family and involvement in program,

Not converted truly to Christ (doctrine but no living Lord) .

Pastor 2) They only know doctrine but have no relationship to Christ,

They are screened out by the church fellowship, Criticism discourages them.

Pastor 3) Battles among church members discourage them, The church members screen them out of fellowship, They are not able to join the fellowship center of the church,

They don't make new friends in the church family.

14) Who makes the decision, in you congregations, as to who is welcome within the church community and who is not?

Pastor 1) Could not say.

Pastor 2) No specific person or group, whole church tests and accepts or rejects.

Pastor 3) Can't answer.

15) When you have an evangelist come to your congregation, who has the primary responsibility for fellowshipping those whom he baptizes?

Pastor 1) The church does, but the new member has some responsibility too.

Pastor 2) The new member, though the church is equally responsible.

Pastor 3) The members of the church are responsible.

16) What is involved, in your opinion, in incorporating new members into your church fellowship and making them active members of your congregation?

Pastor 1) "Truth, friendship, giving them a role and training them."

Pastor 2) Providing acceptance and encouragement to new members.

Pastor 3) Reaching out to new members, helping them become involved, spending extra time with them (individually and corporately) to draw them into church life. 
Pastor's Survey Results-continued

17) What are the basic needs you feel must be met by a congregation in order for new members to begin to feel a part of that congregation and call it "My church?"

Pastor 1) New member needs to become "other centered" by applying the gospel to their lives.

Pastor 2) New members need the benefit of the doubt, love and acceptance, a responsibility in the church fellowship and encouragement.

Pastor 3) They need to have their felt needs met (whatever they are), a caring environment free from criticism, friends and acceptance, and a listening ear.

18) Do your churches have a plan for helping new members become a part of your church body? How does it work?

Pastor 1) No plan yet but working on one.

Pastor 2) No.

Pastor 3) No.

19) What are you doing, personally, to help new members feel at home in your congregations?

Pastor 1) Personal visitation, prayer with them, inviting them to be involved in leadership.

Pastor 2) Pastor tries to "inoculate" them by telling them about the negatives within the church before they join.

Pastor 3) Visitation (On a decreasing scale); pastoral also encourages other church members to fellowship with the new members to help them develop a fellowship group.

20) Are new members to your church staying active, or are they leaving active membership and sitting on the sidelines?

Pastor 1) Yes, they are remaining active.

Pastor 2) They are remaining somewhat active, but some have fallen away and other new members have become depressed by this.

Pastor 3) Question not answered directly. But stated that one church involves new members. 
Members Survey Results

Active and Inactive

1) How long have you been a member of your church?

\begin{tabular}{lrr} 
Member 1) & \multicolumn{1}{c}{ Active } & Inactive \\
Member 2) & 2 years & 2 years \\
Member 3) & 3 years & 2 years \\
Member 4) & 12 years & 36 years \\
\end{tabular}

2) Why do you come to church? Why do you not come to church?

Active:

Friends and acceptance - "one of the bunch" $(3\}$ *

To obey the Bible (1)

Need for fellowship and learning (1)

Inactive:

Attending- to Keep the Sabbath (2)

likes Church (1)

to keep the message (2)

Non attending-

Some in the church did not teach the truth about righteousness by faith (1)

Problems in the home but would otherwise be involved (I)

Health problems sometimes keep me away (1)

Nervous about possible criticism [this is inferred from comments during interview]

3) How many friends do you have in the church? How many friends do you have outside of the church?

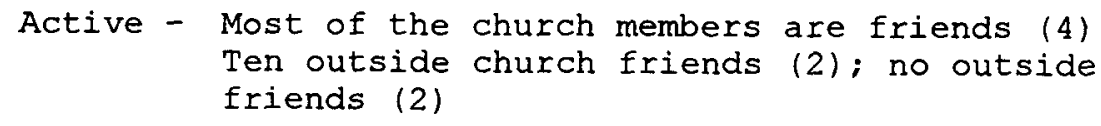

4) Do you hold or have you held any church offices? If so, what are they?

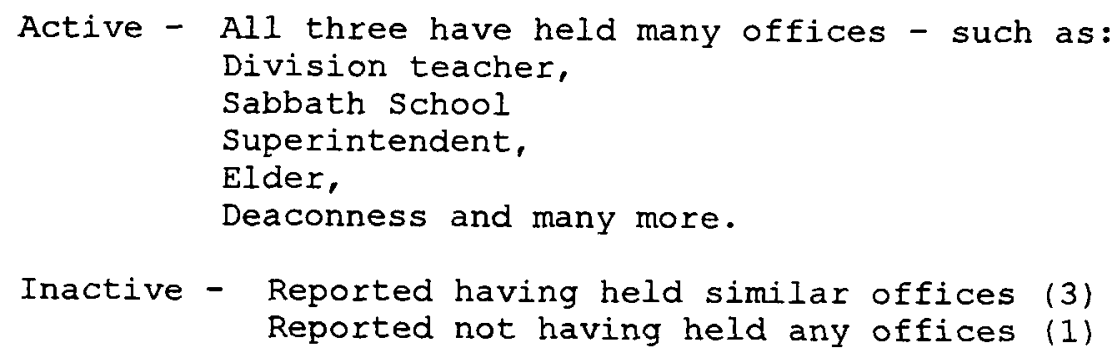

*In this survey result sheet, a number in parentheses (\#) represents the number of responses to a certain position statement. 
Members Survey Results-continued

5) Do you belong to any groups in the church? What are they and how many are there?

Active - All reported involvement in groups like: Prayer meeting (2)

Bible study groups

Choir (1)

Pathfinders (1)

Maranatha Flights

Inactive - None are involved in any groups.

6) Would you say your church functions as:

a) An intimate family group? Yes - Active (1) Inactive (4)

b) A larger family headed by the pastor? Yes - Active (2)

One active member did not think either of these fit,

but that the church ran itself, centered in its program,

since the pastor was not necessary to all functions.

7) Who, in your church, does everybody look to for decisions on what to do and accomplish? Do you know them personally?

Active:

Decision making done by the church board, no individual

dominating outcomes (3)

Decisions made by lay pastor, and they personally knew them (1)

Inactive:

Perceived one person making all decisions and it was a person they knew personally (2)

This was [and should] be the pastor (2)

8) In your opinion, what is an "active church member?"

Active:

An active members shows deep involvement, desire for souls, is involved in more ways than just Sabbath worship services. An active member attends regularly. (I)

Inactive:

Active members attend regularly, pay tithes, and participate. Active members attend regularly (1)

Active members attend and get involved.

9) Do you think your church is open to new people seeking to join its fellowship, or does it tend to ignore them? (i.e. Do others notice and talk to them or not?)

Active and inactive all reported "Yes" indicating that they believe their church is open to fellowship. 
Members Survey Results-continue

10) If new people show up for worship on Sabbath, what usually happens for them?

Active - all reported that they are greeted and welcomed. (4)

Inactive-all reported that they are greeted and invited back.

11) If you were coming to church for the first time as a seventh-day Adventist, and you came to your church, what about that church would impress you the most?

Active - Childrens Program (1)

Friendliness and warmth of the congregation

Musical talent in the congregation (2)

People willing to help out (2)

Prayer service (1)

Inactive - Outward friendliness of the congregation

but it lacks real depth. (2)

The message (2)

12) What experience do you think you would have? (above situation) Would you be likely to return or look elsewhere?

Active - good experience and come back (they did)

Inactive - Would stay if the message was good (2)

Would stay if the fellowship was good (2)

Would be welcomed and would return (2)

13) What are the reasons you think many who come into our churches through baptism and profession of faith leave active membership within a year or two?

Active - Not nurtured and made to feel a part of the church (2) Love is not shown to them (1)

They are not invited into a certain clique (1)

Outside pressure (1)

Persons poorly prepared and rushed into baptism (1)

Not strong enough to resist Satan's attacks (1)

We teach high standards but don't live up to them.

Inactive - They get mixed messaged; no uniformity of teaching

Self righteousness in the congregation (1)

Church members who have forgotten the message and become involved in contradictory behaviors discourage them.

People are not ready when baptized and need more time to get ready. (2)

Outside pressures from neighbors friends and family. (2)

*In this survey result sheet, a number in parentheses (\#) represents the number of responses to a certain position statement. 
Members Survey Results-continued

14) What do you look for in a church in order to consider it to be your church home?

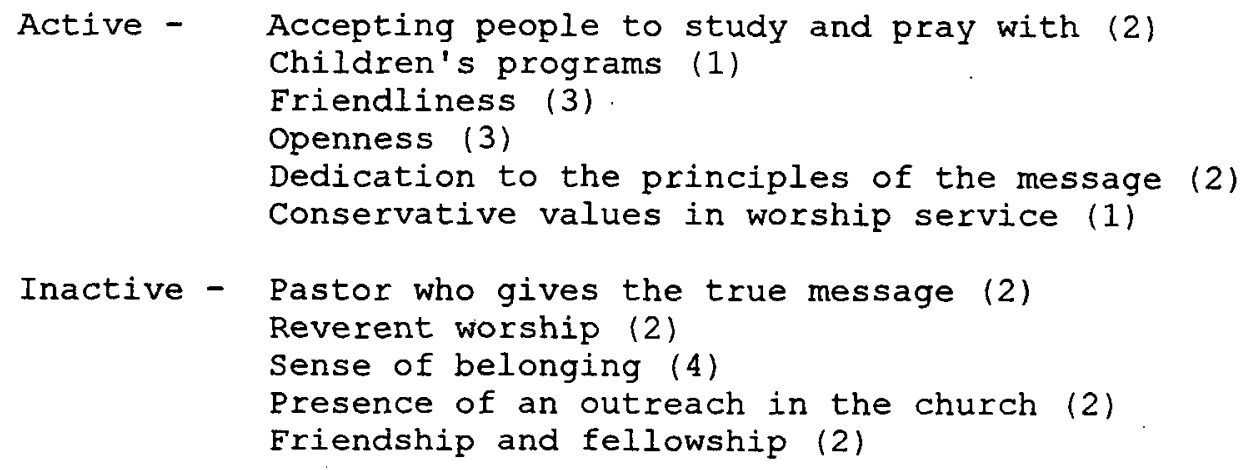

15) When you have an evangelist come to your congregation, who has the primary responsibility for fellowshipping those whom he baptizes?

Active - The church members do (4) The pastor also (1)

Inactive - The church members do (4)

16) How long did it take for you to feel at home and a part of this church fellowship? Who helped you? How?

Active - Felt at home right away (3)

Received help from some (1) [also some hindrance] volley ball program helped make friends, then felt at home (1)

Inactive - Rather not answer (1)

Felt at home after 3 month (1)

"Pretty quick" or right away (2)

17) Are new members to your church staying active, or are they leaving active membership and sitting on the sidelines? Why?

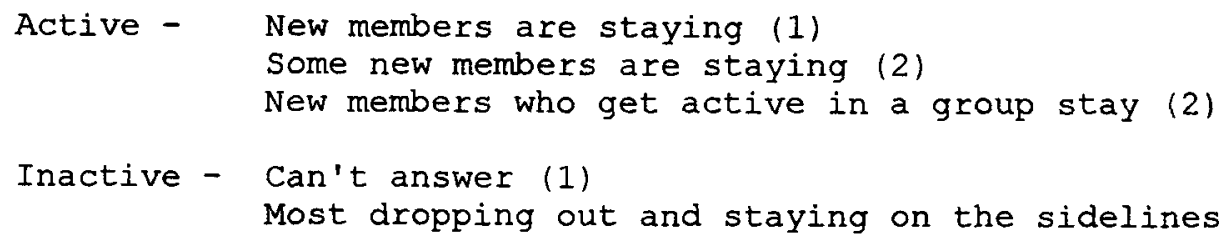

18) Who makes the decision in your congregation, as to who is welcome within the church community and who is not?

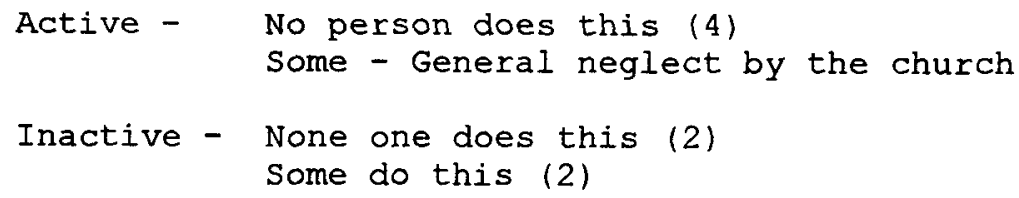

\footnotetext{
*In this survey result sheet, a number in parentheses (\#) represents the number of responses to a certain position statement.
} 
Members Survey Results-continued

19) What is involved, in your opinion, in incorporating new members into your church fellowship and making them active members of your congregation?

Active - Get new members involved (3)

Keep new members out of church office - one year

Someone needs to be assigned to help new members

into the fellowship. (1)

Friendly social interaction with new members at church and outside of church. (1)

Inactive - Spiritual guardian program - really take new members under their wing and nurture them (1)

Accept people with jewelry- let them grow (1)

Be honest in dealing with new members,

let them know we all struggle (1)

Give them time for growth: Don't expect so much from them at first (1)

Invite them to participate (2)

Friendly social interaction with new members at church and outside of church. (2)

20) What are you doing, personally, to help new members feel at home in your congregation?

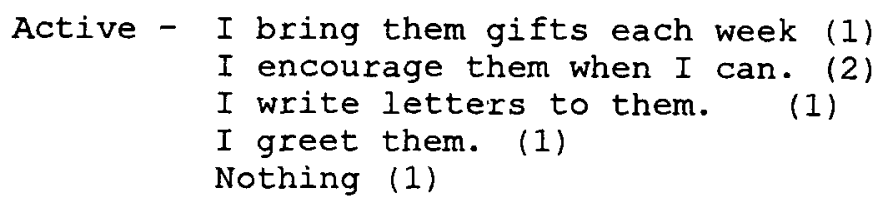


APPENDIX C

THE SEMINAR AND ITS RESULTS 
Scripture Reading: Hymnal \#744 (John 10:1- 9)

$\mathrm{OH}-282$ "I hear thy welcome voice"

MH - 285 "Jesus Calls Us"

$\mathrm{CH}-289$ "The Savior is Waiting"

Ever been shut out from something when you had been led to think you faced an open door? While attending some classes at Andrews University last year, I visited my parents in Grand Rapids, Michigan. I was sitting on their back porch when I heard strange sounds coming from the neighbor's driveway. They went: "Flutter, Flutter, Flutter-Flap, Flap, Flap"

Curious, I scooted my chair about to see what caused it, and I saw a pair of sparrows hovering near the upper left corner of our neighbor's garage door. The male was hanging on to the molding, but the female was resolutely attacking the crack near the top of the door, trying with all her might to get in. Hence, the "Flutter - Flutter, Flap-Flap".

I watched her off and on throughout the day. She never got in. And never stopped trying.

Now our neighbor usually leaves his garage door open, so I could guess what had happened. This sparrow family had come along hunting real-estate and thought they had found the perfect (to sparrows) condominium. The door was open, the rafters solid, and no cats in the neighborhood, so they made the decision to move in. There was probably a period of several days to a week while Mrs. Sparrow and her mate gathered grass and materials, made a nest, and then laid the eggs so the nest could go into production.

These Sparrows had every right to believe their little haven would be secure and happy throughout the summer, until one day, my erstwhile neighbor (and their unwitting landlord) discovered he had sparrows in his garage and closed the door. The Sparrow couple was shut out from what, to them, had seemed a good thing.

Shut doors equal disappointed hopes. Have you ever encountered them?

The sparrows' experience illustrates what a lot of us go through, doesn't it? They had reacted in faith to the promise of an open door; the promise of shelter, security, even community (for there were other sparrows present). They had invested their time and effort in setting up their nest within the confines of this promise, which involves not placing their home in some other neighborhood. They had placed their precious eggs in the nest in the hopes of raising their children in a secure environment. And now, after all this time, effort and emotion, they find themselves screened out, shut away, not wanted. No wonder they were upset.

Sometimes our churches can be like that garage. They appear open to receiving new members. [We baptize anyone who will agree to invest in believing and keeping the 
standards of our message.] But while membership is granted easily to all who want it, inclusion into the inner "fellowship circles" of the church is more difficult to achieve. And that is why we often have people attend church for a while, but then stop attending. \{Roy M. Oswald and Speed B Leas, The inviting Church, Alban Institute, 1987 p. 33\}

They came to us believing the message and looking forward to becoming part of a community of faith. They invested all they had in the promise of becoming part of "God's remnant people" only to come into the church one day to find the doors to any satisfying fellowship experience closed to them. And what makes this even more painful for some is that not everybody is screened out of the church.

That, too, is true for Sparrows.

While watching my sparrows struggling to get into the garage, I noticed another sparrow and resident of the premises. She would land at the bottom of the door (usually carrying some piece of straw, etc.), look about a moment, and then slither under the door at an imperceptible gap at the bottom. The door that was shut to the Mr. and Mrs. Sparrow above, was no problem for Sr. Sparrow at the bottom. But did she show her strugaling comrades how to get around the door? No way. I don't think she even noticed them.

[This afternoon we will discuss the informal and unconscious "screening" that new members always encounter before they are granted full access to our churches (or any organization for that matter. For now, please note that it is there, and very real.] So, in the interests of promoting the ability of our church to include new members more easily into its fellowship, Let me ask you this question:

How many doors are there into your church? Into your real church fellowship?? Of course, we all know the door spoken of by Jesus in John 10:

1. "I tell you the truth, the man who does not enter the sheep pen by the gate, but climbs in by some other way, is a thief and a robber.

2 The man who enters by the gate is the shepherd of his sheep.

3 The watchman opens the gate for him, and the sheep listen to his voice. He calls his own sheep by name and leads them out.

4 When he has brought out all his own, he goes on ahead of them, and his sheep follow him because they know his voice.

5 But they will never follow a stranger; in fact, they will run away from him because they do not recognize a stranger's voice."

6 Jesus used this figure of speech, but they did not understand what he was telling them.

7 Therefore Jesus said again, "I tell you the truth, I am the gate for the sheep.

8 All who ever came before me were thieves and robbers, but the sheep did not listen to them.

9 I am the gate; whoever enters through me will be saved. He will come in and go out, and find pasture.

Who is the doorway into the church? JESUS IS THE DOOR, JESUS IS THE ONLY 
It is not right for us, as church members, to section off the sheepfold with other gates and doors, and screen those who would enter among us, once they have been baptized into Jesus Christ. Jesus says of himself, "All who come unto me, I will in no wise cast out." (John 6:36) If we are like Him, neither will we.

Lets look more closely at this text to discover Jesus' council concerning our fellowship in the church.

1. "I tell you the truth, the man who does not enter the sheep pen by the gate, but climbs in by some other way, is a thief and a robber. Jesus is clear here, there is to be a wall around the church, but no walls within the church which require doors.

We are not to allow people to come into our fellowship who have not come through the door, Jesus Christ. We need to be careful that those whom we prepare for baptism are truly instructed and converted to the faith of Jesus Christ. Without Jesus at the heart of the church, there is only pain and disappointment. People in our fellowships, no matter how long they have been here, who have not truly received the Lord of our fellowship will be a source for contention. They become involved in power politics in the body. They will form "cliques" and seek power over others. They will bring in principles that are not in harmony with the Law of Heaven, the Law of Love.

There is enough backbiting and slander practiced in our churches already. Those who have entered by the "Door" of Jesus Christ would never participate in such things. Such "thieves" rob the church of its fellowship by destroying the trust upon which fellowship is based. We should be careful not to bring people into fellowship who have not yet discovered the power of faith in Jesus Christ, and received Him as their personal Savior and Lord. That is what the Watchman is for:

2 The man who enters by the gate is the shepherd of his sheep.

3 The watchman opens the gate for him, and the sheep listen to his voice. He calls his own sheep by name and leads them out.

When a person enters by the gate they must first face "the watchman". In our church the "watchman" makes sure that the testing truths of our message have been understood and accepted. These truths show that a person has indeed received the love of the truth of God and the desire to follow Jesus, even when the way is narrow and inconvenient to them at the moment. The watchman is, first the pastor; then the Church board, and finally the church body (which alone can vote candidates into fellowship). This is done before any baptisms take place.

Once the watchman is passed, and the person enters through the gate of Christ in Baptism, they should experience the open fellowship of the members. There are to be no other barriers or watchmen to pass. 
People stay as members of a church for a number of reasons. One of the biggest reasons is that they feel welcome and included in the life of the church. \{John S Savage, Kenneth J. Mitchell, Joyce C. Nelson, Lab I Leader's Guide, p. 8\} You and I know we are welcome when people talk to us and listen to what we say in return.

If you have ever come into a room filled with strangers and suffered, as I have, their silence and inattention, you will know what people experience when they attend a church which has said "you may be a member here", and yet found nobody who extends the hand of friendship.

Research shows that "Congregations have paid little attention to socialization. We are told that half the new members who join a congregation disappear within two years. ... That is terribly costly. But beyond that, the congreaation has violated its own beliefs and values. They have failed to receive and give hospitality to one of God's children who was seeking to make a home in the community." (Loren Mead, More than Numbers, $p$ 78,79)

The big word here is "ASSIMILATION". The process by which a person becomes a part of our church fellowship. "Assimilating someone into the life of the church is different than helping them become members. . . The church needs to incorporate them into the life the emotion the ministry of the conareaation. People need to become a part of the church body rather than be merely attached to it." \{John Savage, "The Teflon Church", Leadership, 11(Fall,1990):31\}

What I am saying is that there is a need for "doors" [of a kind] into the fellowships of our churches. Social "doors" or openings, allowing people as many access points into the life of the church as possible. If we do not consider how these doors can be provided, we have no business engaging in any type of evangelism, for we are just wasting the Lord's money.

"In preparation for the newcomer the leadership [of the church] needs to provide for, and be aware of, multi-entry points into the fellowship circle of the congregation." These entry points may be classes, men's or women's fellowship circles, youth programs like pathfinders, service projects, choir, study and fellowship groups in the homes. "Whatever the group, each one offers another opportunity for newcomers to make contact, to find people with similar interests and values, to participate in satisfying activities and to build new relationships." \{Arlin J. Rothuage, Sizing Up a Congregation for New Member Ministry, p. 18\}

How many such groups are needed? Here is a rule of thumb. In a strong church of one hundred members will have six to eight face-to face small groups "where membership in the group is important to the members of that group." Less than this number will stifle any growth of the congregation beyond this point. \{Lyle Shaller "Twenty Questions for Self Evaluation in the Small and Middle Sized Church." Church Management 8(April 1977): 15\} 
"The assimilation process functions smoothest when the stranger Inew memberl is recognized as needing to be helped into the congreaation. One does not feel welcomed if he or she is left alone, unattended, feeling lost and helpless." The skill of recognizing this and applying it is the gift of hospitality. \{Oswald \& Leas, p. 51\}

In a recent article for the Adventist Review, Leo Schreven, evangelist for Amazing Facts, wrote of four "Crises" that new believers face within the first two years after baptism. They are: The Crisis of Discouragement - experienced when the new believer lets himself down. The crisis of Integration - which happens when new believers have difficulty replacing "old friends" lost when they accepted Jesus, with "new friends" in the church. The Crisis of Lifestyle - experienced when trouble comes with integrating Adventist standards into their behavior. The Crisis of Leadership - when they see the inner working of the church and realize that their brethren are not as perfect as they had thought.

Schriven writes: "During the first six months, more individuals leave the church because of the crisis of discouragement or the crisis of integration than for any other single reason." ( $P$. 13) "In each of these crises, one maior ingredient can help avert apostasy: Caring love." \{Leo Schreven, "New Members and the Disappearing Act" Adventist Review, October 7, 1993, p 12-14\}

When a person enters our church and "The watchman opens the gate for him," it is "the sheep listening to his voice" and responding in true Christian fellowship and love that will show that he or she is welcome among us. As Jesus, Himself, commanded us in John 13

34 "A new command I give you: Love one another. As I have loved you, so you must love one another.

35 By this all men will know that you are my disciples, if you love one another."

The love we show our fellow members, whether new or old, is the sign by which Jesus said we would be known. Friendship holds the key to keeping most people active. Studies have shown that the difference between the new members who stay and those who leave is in how many friends they make in the church in the first 6 months. Russell Burrill, director of the North American Division Evangelism Institute, kept records on his baptisms from meetings in Spokane Washington. He found that $68 \%$ of the group of those who stayed active in the church after baptism had made six or more friends during the first $\underline{6}$ months in the church, while of the group of those who dropped out, $68 \%$ had not. \{Russell Burrill, Survey of People Baptized at Public Evangelistic Meetings in Spokane, Washington. Graphs 17\&18\}

Other studies have shown that people who make at least 7 or 8 new friend in the church almost always remain active in its fellowship. People with less than 4 friend nearly always drop out. \{Robert L. Bast, Attracting New Members, 1988, p.94\} in John 10, 


\section{Manual for Seminar on Assimilation}

Page 6

7 Therefore Jesus said again, "I tell you the truth, 1 am the gate for the sheep.

9 I am the gate; whoever enters through me will be saved. He will come in and go out, and find pasture.

Jesus' promise to all of us who come into contact with the church through Him is that we will: Be Saved (from sin and death), come in and go out (have free access to the fellowship of the church and the kingdom of God), And find pasture (peace in God's presence and the presence of his people).

Jesus has placed his word on the line to us, and all who come to be among us. He has commanded those of us in the church to receive new members, duly baptized into Jesus Christ, into our fellowships and share with them the same brotherly love and kindness we ourselves enioy in the church. (John 13:33-35) And He has promised all who come to be among us through $\mathrm{Him}$ that they will be received in the love He has commanded us. Dare we, as His remnant children, give any less to our new members and to our older members than he has commanded?

\section{I don't think so.}

For if we do not show the love he promised we would, we make him out to be a liar in the eyes of all who have eyes to see, and we destroy the gospel by which we have hope of salvation and a better life. Ihe Savior is waiting to enter our hearts and fellowships so that he might invite multitudes of his other friends to come and be with us here. Are we willing? We are told:

If we would humble ourselves before God, and be kind and courteous and tenderhearted and pitiful, there would be one hundred conversions to the truth where now there is only one. But, though professing to be converted, we carry around with us a bundle of self that we regard as altogether too precious to be given up. It is our privilege to lay this burden at the feet of Christ and in its place take the character and similitude of Christ. The Saviour is waiting for us to do this.

9T 189

Let us open ourselves to him today. What do you say? 


\section{Manual for Seminar on Assimilation}

Page 7

\section{Seminar Portion for Sabbath Afternoon}

\section{Group Building and Survey Findings}

Prayer

Division into Pairs [or triads] -
[1 min]

[2 min]

1. Everybody find a partner [one may need to triple up]. This person will be your learning partner for the remainder of the seminar.

2. Sit face to face with your partner, and spend the next 2 minutes in conversation.

+ Catch up on your friendship, or get acquainted if you choose someone you do not know well yet.

\section{Survey findings [32 $\mathrm{min}]$}

+ Pass out the Summary Sheets and Copy of survey.

++ Have entire group face front.

Introduce: - There are no "right" or "wrong" answers in this survey. 2 minutes

- There are only portraits of what we are right now.

- It is up to you, each one, to decide if the portrait you see of this church is a picture you want to have continue, or if you want to see a change in any part of it.

- Some behaviors and attitudes will bring forth results that help members to stay active in the church, some will not.

- We will try to point out a few of these as they relate to this church situation., and we will allow you time to discuss your feelings about them, and hopefully you will see what you want to do regarding them.

Read the Summary Sheet first. [separate handout] 3 minutes Specific Findings Regarding Assimilation:

15 minutes

(This lecture is an example of one given to a specific church. These findings would vary from church to church.\}

With respect to Assimilation, the shows numerous positive indicators in its beliefs about the needs of new members.

This, in spite of the fact that over $50 \%$ of the membership [ $64 \%$ of those taking the survey] have been members of the church for 10 years or more. \{See Question \#1- Church growth experts have discovered that where over $50 \%$ of the members have over 10 years tenure, the congregation will have trouble assimilating new members. - Lyle Shaller, 20 Questions\}

-Questions 8, 12, $1719,23,24,25,29$, and 34 were used as indicators of how church members felt toward receiving new members and church growth in general. 
-Questions 8, 17 and 34 give an indication that church believes in growth, at least as an ideal to reach for.

$-100 \%$ of the survey said "No" to the thought that the church was growing fast enough already. This was consistent for all age groupings. In Question 34 we see the same pattern where all members unanimously disagreed that "the church is just the right size."

-In evaluating the church growth, there were interesting correlation's between this and questions 18, 20, 26,31 , and 32. These questions asked how members thought the church was doing in various areas related to growth and assimilation.

--Q. 18 "It is easy for new comers to become part of this church family" $Y=\underline{39 \%} \mathrm{~N}=61 \%$

The perception of $\underline{2 / 3}$ of our members is that the church does not receive people easily. 1 to 5 year members are the most pessimistic. $100 \%$ of these believe the church does not receive new members well. This dissatisfaction can be a positive thing if it leads you all to consider how to prepare a better place for new members to be fed and cared for.

-Q. 20 We need a better outreach program in this church." $Y=\underline{96 \%} N=\underline{4 \%}$

The body is open to change here in hopes of greater results.

-Q. 26 "This church is friendly to visitors and makes them feel at home." $39 \%$ said "Always" $46 \%$ responded "sometimes", and about $14 \%$ felt the church lacks heavily in this area. The friendliness of a church atmosphere is a strong indicator that it can receive new members into fellowship but the church body itself is least able to determine whether a church is friendly to visitors. Note the visitors give you better grades than you give yourselves. $67 \%$ consider the church to be "always" friendly. And none disagreed with the statement at all. It is the visitor who experiences what your hospitality is really like. It is therefore important to listen to them and their concerns while planning to improve the assimilation climate of a church group.

-Q. 31 "This church meets my needs" There is quite a spread in this area. $\underline{0 \%}$ in recent members "strongly agree" or "agree" with the statement. However, the visitors and older members felt their needs were quite well met, $67 \% ; 71 \% \& 63 \%$ Respectively. The needs fulfilling ability of the church is a factor in decisions to stay active, though there are always some who will hang on no matter what. $61 \%$ was the number who agreed, overall.

-Q. 32 "New members who join this church stay active in its fellowship" The bulk of answers to this question center in the "Sometimes" group [69\%]. In reality, we have been keeping about half. 
-There are some interesting comparisons between the "ideal" and the "real" noted in the survey. The "ideal" is what we strive for but the "real" is what we get. Some of these came through in questions 17 when compared with Q's 21 and 33.

--Q. 17 "I believe this church should reach out and bring in new members." showed an encouraging $100 \%$ yes, affirmative response. When asked if they would like to win souls enough to set time aside for a training program in wining souls $\{Q .21\}$, the number dropped to $75 \%$. This is still good, but the difference indicates that some are not ready to follow their belief in this area with action.

It is expected that some will pull back when confronted by the cost of growth, but the overall majority in the church surveyed indicate that they are behind the Three Angel's Message, and will sacrifice of their time to carry it to friends, neighbors and even strangers (or at least learn how to do so). Q. 33 showed a similar pattern. When asked what their behavior pattern has been with respect to attendance at evangelistic meetings held by their church, $9 \%$ indicated "Always" and 59\% said "Sometimes," while "Seldom" and "Never" each received 3.7\%

-Many of us need to realize how important our presence at such meetings is to the assimilation of new members into the church. New members need to make friends in the church, not only to bridge them into the church but to keep them there and help them remain active. The best time to begin those friendships is the evangelistic meeting. Members should not attend to hear the message. They alreadv know it. They should attend in order to welcome the people, and get to know them personally. Then when they come to church to keep the Sabbath, they will already have friendly faces around them and they will not feel so out of place.

--Your attendance at evangelistic meetings, if carried out in this manner, can be more important, in this respect, than that of the evangelist. Believe it or not.

-Perhaps this would be a good time to mentions a statistic that greatly concerns me concerning our church fellowship. In Q. 22, when asked to respond to the statement "I am happy with the fellowship this church gives me." the overall affirmative response was $\underline{50 \%}$ "Yes". But when this is compared with the response by church age groups, we find that the younger members are $100 \%$ unhappy with the fellowship and the 6 to 10 year members are also dissatisfied (71\% said "No"). Only the older group of members and the visitors appear happy with the fellowship we have here, but even that is not a really strong. This is something we need to explore and find answers to, or we could find ourselves not only unable to hold new members but also losing the ones we have.

The final area we will look at is the importance of friendships and nurturing friendships.

-Q. 25 said "I believe in actively including New Members in what I am doing in this church." To this, $\underline{89 \%}$ gave a "Yes" answer. 
This is exciting because it shows awareness that new members need to become involved and make friends quickly if they are to stay. Research shows that new members need to make 8 new friends in the first 6 months in the church family. That's a tall order. Therefore, it is important to ask ourselves what practices, on the part of the established membership, will help them do this. And the answer is, the practice of "personal involvement", or "active friendliness."

So how are we in "active friendliness" in the church?

-Q's 27, 28 and 30 show us three areas of active friendliness and how we are doing.

--Q. 27 "I try to speak to New Members and make them feel at home any way I can"

$\underline{0 \%}$ said "Always" and $11 \%$ said "sometimes" That shows that only $1 / 10$ th of the membership who are actively seeking to engage in friendly discussion with new comers. This is one of the best ways to show a person that they are wanted and valued parts of our church fellowship.

-Q. 28 "I have invited new members to fellowship at my home this year." It is realized that not everybody has a home suitable for this purpose, but of those who did there are many who indicated that they used the homes they had for this purpose. $5 \%$ of the membership who can, "often" did this service and $\underline{14 \%}$ "sometimes" extended hospitality in this manner. This shows only $\underline{19 \%}$ of the surveyed members who can, exercise their gifts of hospitality in befriending new members this way. It is in the home that NM's will find the friendship they most need to have. It was part of the growth secret of the early church "and breaking bread from house to house" Acts. 2:46.

-Q.30 "I try to introduce new people to my other friend at the church." Nothing you can do will help new members become a part of the family more than this single and generous effort. $12 \%$ said they "always" introduce new members to their other friends. And $\underline{56 \%}$ said "sometimes" they do this. Only $\underline{20 \%}$ seldom introduce new people around and among their friends and acquaintances, and this may be because they are shy themselves. $12 \%$ do not do so at all.

-if $68 \%$ regularly perform this function, they can form a nucleus for assimilation within the church just to help new people.

--We can all improve in these areas, and all of us should be noticing when a new face appears, and step in immediately to make friends, especially if they appear lost and unsure of what to do or who to see and talk too; If they appear lonely.

Discussion in small groups -

6 minutes

-Turn to your partner, and together find another team, forming groups of 4 or 5 or 6 .

-I want you to discuss what you have learned about your church and yourself in these 20 minutes.

-The person with his or her back to me can be the discussion leader.

-Use this question I am writing on the board to get started. 
What have I learned about my church?

What have I learned about myself?

You have 6 minutes

Sharing Learning in Large Group -

6 minutes

Break into the discussion and have them face the board.

Write "Learning" at the top of the board and ask participants to relate things they have discussed in their groups. 


\section{Manual for Seminar on Assimilation}

Page 12

\section{Screening Experience [14 min.]}

Please take your partner, and find two other pairs, and sit down in a group, facing me.

We will now move into a controlled experience that has opened many people's eyes.

What I want to do is help you become aware of screening behavior and the feelings it produces.

Lecture on Screening:

$3 \mathrm{~min}$.

- In his study of why people leave the church, Dr. Tim Savage, author of The Apathetic and Bored Church

Member discovered a great deal concerning the behavior of the active church members as well as the inactive.

-The local congregation knows who it wants and who it doesn't want in its membership.

-The congregation develops highly sophisticated and subtle screening behaviors, so subtle in fact, that the average congregation is unaware of its behaviors.

-The inactive member is a screened out member.

-One of the objects of this seminar is to teach you how to recognize and intervene in this process.

-Observations about screening behaviors can become slightly painful.

-I would like to have you experience a blatant screening device, a little simulation game, for only one minute.

Screening Exercise- * use board or flip chart

2 min.

- Each person in the groups of 6 (or 5) take a number from 1 to 6 (or five if you have only five)

PLACE NUMBERS ONLY ON THE BOARD

NOW ADD TASKS TO THE NUMBERS WHILE VERBALLY GIVING THEM.

(task adjustments for group of 4, if have one are -1 and 2 talk, 3 tries to get in; 4 observes)

- Numbers 1-2-3 will begin a lively conversation about anything.

- Number 4 will try to break into the conversation anyway he/she can. Use all your skills of entry.

- Numbers 1-2-3, no way are you to let \#4 get into your conversation (short of physical harm). Keep \#4 out.

- Numbers 5-6 will observe without becoming involved. Listen and watch for behaviors and body language.

- Please stand for this experience. ONE MINUTE ONLY!

\section{Small Group Reflection:}

$5 \mathrm{~min}$.

- Be seated.

- I would like to know how many \#4's got in?

- Please note that our screening behaviors are well developed.

- Our culture teaches us how to screen - not how to get in.

- that little exercise has a lot of learning in it. Even in games, real feelings are generated. 


\section{Manual for Seminar on Assimilation}

Page 13

- Number 4, you will begin the discussion in your group. What gets triggered? We all have known those feelings, especially as teenagers.

- What if it had gone on for 5 minutes?

- What if that had been reality, and not role play? What would you have done?

- Numbers 1-2-3 share what it was like to deliberately keep someone out. (You are good at it)

- Numbers 5-6 share what that looks like.

- Describe behaviors and body language.

- When you see or hear that happening, what do you experience?

- Begin your discussion now

-4 minutes.

\section{Total Group Reflection}

$4 \mathrm{~min}$

+ Get feedback from group discussions using same type of questions above.

- Do you recognize screening in your church?

- What does it look or sound like?

- 4 Minutes.

[Note to those reading this appendix. This material has been taken from the Lab 2 training manual developed by Dr. Tim Savage of LEAD Consuitants. This material should not be used except by qualified graduates of the Lab 2 training seminar.] 


\section{What Holds People in a Church? [13 min]}

\section{Lecture:}

Let me share why it is that some people never drop our of the church?

There are three key issues: Faith - Friends - Groups [Draw 3 legged stool]

Nurturing life in the church involves strengthening all three.

When all three are stable, the person remains active.

But like the stool, when one leg breaks things get wobbly.

Faith-

- Active members have an active faith.

- But people go through periods of doubt in their life. Call them "faith spasms".

- When our faith goes into spasm, we begin to think we do not belong in the church any more.

- The question is, can the church stick with the person, even in the pain of his/her doubting?

- There are several classic times that adults face these doubts.

\section{Age 17-25 - Young Adult.}

Tasks: Seek mate, Seek occupation, Seek theology. (Who will I marry, What will I do \& believe) We are loosing a tremendous number of youth in this area.

\section{Age 38-42 Mid Life Crisis}

Same issues as in youth resurface.

Things surface because life has become routine and you wonder (is this all?)

And you begin to wonder if the box you had everything in your life arranged in might has become a prison.

\section{Ages 50-55 is called "Empty Nest"}

Question, What will I do in retirement?

Ages 65 and up - Retirement.

Facing death (parents both gone) Time of loss, of giving up.

- In each of these areas, and at each of these times, Faith must be reforged our of your own personal experience. People must give up the religion and faith of their parents and discover their own. 
Friends.

- Relationships are very important to all of us.

- What happens in the church when your friends leave? Your membership becomes shaky.

- Sometimes our people move to another area, and stop going to church. Why? It's not like home. No friends there like at home.

- Research shows that members need from 7 to 8 friends to feel good in this area.

\section{Groups -}

Most active members belong to some kind of group in the congregation.

Most often it is a family group, or a choir; A Sabbath school class, or a study/prayer group.

It may even be the church board. <Grin>

When you go through periods of doubt, you need friends and groups in the church to support you.

One reason we loose the young adults is:

Their faith is in spasm

Their friends move away (to academy or college)

So their groups disappear.

Whammy!

[Note to those reading this appendix. This lecture is taken and modified from materials developed in the Lab 1 and 2 training workshop by Dr. Tim Savage of LEAD Consultants] 


\section{Manual for Seminar on Assimilation}

Page 16

\section{Lecture on Church Structure [ $16 \mathrm{~min}$.]}

+ Have entire group in large circle about the white board.

+ Do a mapping of the church as you discuss the Sand Dollar Effect - from Carl George p. 64-67

The Sand Dollar Effect lecture

$10 \mathrm{~min}$.

- The church growth researcher, Carl George, has noted that church group tend to level off in growth when they reach 50 to 150 members due to their organization.

- The congregational sized organization, with everyone trying to fulfill their church program and personal needs within a group of this number, has several limitations.

Limited intimacy and fellowship

Limited accountability

- Basically the group is too large to promote real person to person communication and sharing.

- It is also too big to comfortably include everybody in that is going on.

-The result is something called "The Sand Dollar Effect."

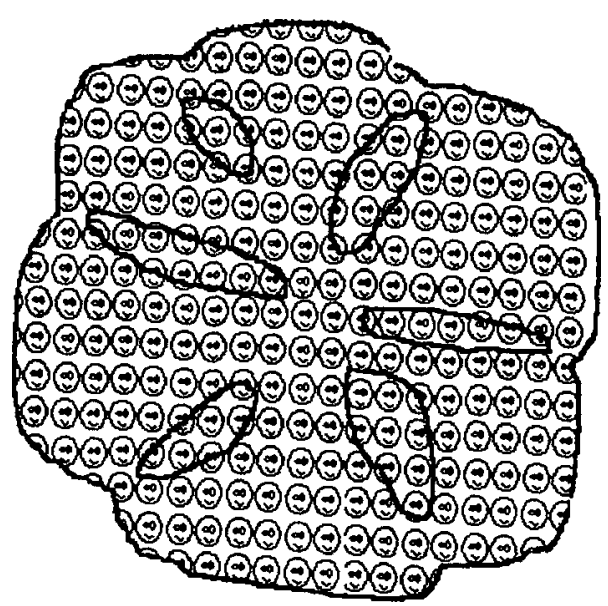

There is a tendency for the congregation to fall into the sand dollar pattern. \{draw design church\}

-Like the sand dollar's star embossing, a series of overlapping cliques of people are found within a church, bound together by past experiences, common interests, and family ties.

-The rest of the church occupies the spaces outside of this close, clannish structure of friendships and alliances.

-These peripheral people are participants in the congregation, but they know they are not insiders.

-The star insiders constitute the power of the congregation and form something like a church within a church.

-These people may or may not hold church office, but they determine what happens and what doesn't. 
-Newcomers who attempt to assert themselves find that they have to fight for acceptance.

-If they make the proper alliances and friendships with members of one of the cliques (the inner circles, they survive.

-If they do not, they become alienated and drop away.

-New members cannot force their way into these inner circles.

-They must be invited in.

If they weren't part of the clique's formation, or political chemistry isn't just right,

or if someone else has just entered the only available opening, then they find themselves in the peripheral zone.

-The clique members have decided long ago that peripheral people are not very stable.

After all, they seem to hang around for a while, make a few critical comments, and then drop out and quit!

-The inner core people don't realize what is really going on, for in their church within a church, they comfortably minister to one another and do not see their institutionalized neglect they practice toward the marginal people.

Lets look at our sand dollar and fill it in for this church. And please, realize that these groupings are not bad or good, they just are. It is what we decide to do with our power that is important.

Most of the other active members of this congregation will probably connect to one of these three families.

[Note to those reading this appendix. This material is taken from the book, Prepare Your Church for the Future, by Carl F. George. pp. 64-67] 


\section{The Family Church}

\section{0-50 Active Members}

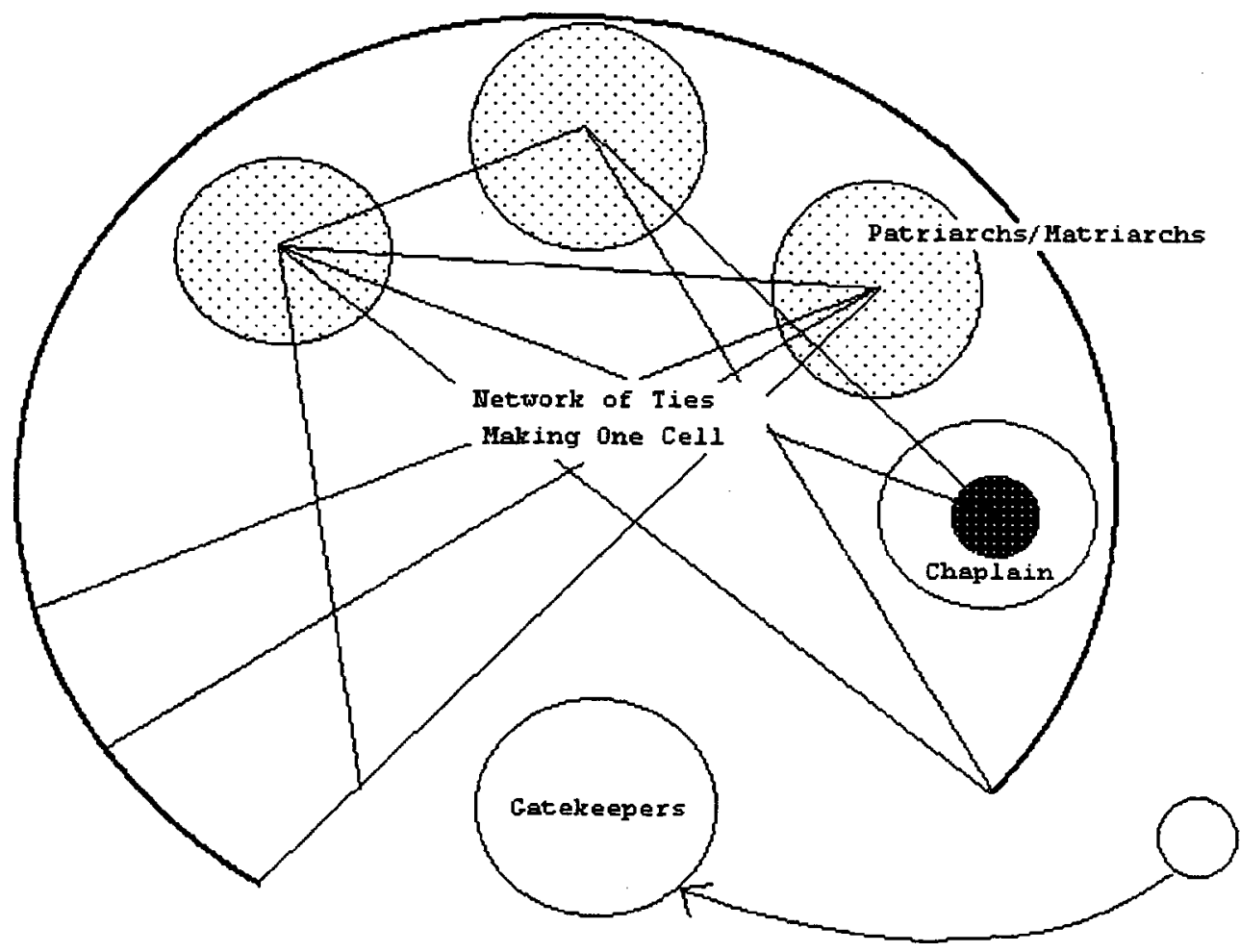

-Carl Dudley points out that the small church has the basic dynamics of a one-cell unit, such as a family with strong parental figures in control of the norms and changes in the family life.

-The Pastor, in this situation, functions as a Chaplain, not as primary leader or father.

-Members who can get into the family are loved and cared for intimately, but "getting in" can be tricky; as you would expect from a close and sometimes closed family.

-Newcomers must be helped in by a "gatekeeper", who serves the role of "cheerful, welcoming, kind person."

-The "gatekeeper" opens the door, but it is the patriarch and matriarch who sanction a place in the family for the newcomer.

-The method of assimilation is more like adoption than simple social acceptance.

-Adoptions take longer than social acceptance, but the bond with the new church family will be very strong. 


\section{Characteristics of Entry into a Family Church}

-New Members come mostly through the strong family and friendship ties of the members, some of which have existed for generations.

-A newcomer will most often already be known by somebody in the church and by the "gatekeeper."

Grace and sensitivity on the part of the church to the new relationships is extremely important.

-Adoption into the church family will be a long term affair but it should not be overly extended.

-The Newcomer has four basic needs when he/she comes to the family church.

1. The need to learn the heritage and traditions of this congregation so that he/she can fit in comfortably and knowledgeably. Until this is learned, he/she will always feel off balance in conversations where "Adventist speak" is used.

- arrange contact with a retired patriarch/matriarch who functions now as "lore giver"

- give the new member a brief history and church membership listing.

- provide a guide (perhaps family or friends already in the church) to help them get acquainted and learn the life of the congregation.

2. Acceptance and recognition beyond the ritual contact with the "gatekeeper." This is particularly needed outside of church gatherings; at the grocery store, service station, hardware, etc. Church members should be warm and receptive in all normal daily contacts.

- encourage church members to identify and seek out the new member at all church gatherings.

- encourage support and appreciation to be expressed for the newcomer among the members.

3. Acceptance by the "patriarchs and matriarchs" of the congregation. Contact needs to be arranged to facilitate this association gradually, over time.

- be interested in the newcomer and learn about their life, especially anything that would provide "contact points" with other members, and particularly with the patriarchs and matriarchs.

4. Safe opportunities and safe persons with which to discuss his/her association with their new family of church relatives. There will be awkward moments, and they will need to sound out their feelings with somebody who will not gossip.

- The chaplain can be ready to listen whenever the newcomer needs to share something confidential.

The small church of this size usually functions as a family with the dynamics of a family, following the parental lead of a few patriarchs and matriarchs.

It is difficult to gain acceptance/adoption into this rather close network of family relationships.

Well informed "gatekeepers" and sensitive "chaplains" and accepting "members" and "patriarchs and matriarchs" can help the newcomer enter.

[Note to those reading this appendix. This material is drawn from Arlin J. Rothauge's book, Sizing Up a Congregation, pp. 7-13.] 


\section{Lecture: What is needed? A Place to put new people - [15 min.]}

Lecture "Cell Groups" or "Adoption?"

Limitations of congregation sized groups have already been mentioned:

Limited intimacy and fellowship

Limited accountability

Limitations of Adoption in the Family Church is that many cannot be adopted at the same time. And it takes a long time for the family ties of a single cell church to develop.

We need places to put new members right now, if we are to fulfill the commission of the 3 angels messages. We need places to put new members:

--where they can make friends with a solid company of the older members.

--where they can experience close relationships with 7 to 8 other people.

--where they can minister and be ministered to in caring fellowship.

--where they can know they are wanted and appreciated regardless of what else might be going on in the church.

The best answer to this need is called: Cell-group or Small Group Structure

This is a plan that comes directly from God.

We see in Acts 2

We find it in the Spirit of Prophecy as a device to help us grow.

The formation of small companies as a basis of Christian effort has been presented to me by One who cannot err. If there is a large number in the church, let the members be formed into small companies, to work not only for the church members, but for unbelievers. If in one place there are only two or three who know the truth, let them form themselves into a band of workers. Let them keep their bond of union unbroken, pressing together in love and unity, encouraging one another to advance, each gaining courage and strength from the assistance of the others. ... As they work and pray in Christ's name, their numbers will increase; for the Saviour says:

"If two of you shall agree on earth as touching anything that they shall ask, it shall be done for them of My Father which is in heaven." Matthew 18:19.

7T 021

Rebuilding the structure of the church around this model is our solution, but also costly in terms of change and initial stress for the congregation. It could take 5 to 10 years for a church to complete the switch from the Congregational Structure to the Cell-group Structure. 
Cell Group - Structure of Group

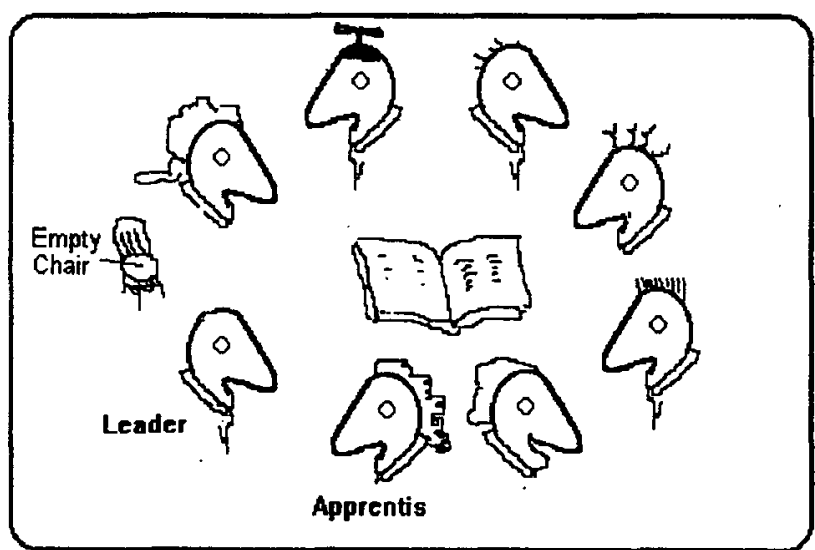

In the Cell-group structure, every active member of the church belongs to an intense, face to face fellowship, study and mission group of 6 to 16 other active people. Each group has a leader trained by the pastor, and an assistant/ apprentice leader. As the group grows to 16 members, the group will be prepared to split into two groups, the leader continues with one group and his/her assistant becomes leader of the new group. Each group then chooses a new assistant leader, who will learn the art of guiding a group in preparation for having one of his/her own when the group again grows to the point of a split.

This is the model of church organization that comes closest to the pattern set out by the Spirit of Prophecy in the quotation above. It is prescribed to us by one "who cannot err."

[Family Church Lecture- skip from here to the conclusion before the group discussion since the information on the next page was already covered in the lecture]

In the meantime, there is something else we can do while considering the Cell-group structure and how to implement it in the home church. It is the only other means of assimilation available to the congregational sized small church as well as the Family sized small church. It is called, "Adoption". [this page can be skipped if working with the Family Church, since this was covered in greater detail in their lecture.]

Adoption is the act of taking a new member under your individual care and bringing them into your own church family groups.

Help them to learn the history of the church.

Introduce them to the formal and informal leaders of the congregation.

Include them in all that you do until they have developed their own network of friends in the church.

The primary draw back of adoption, as a method of assimilation is time. 


\section{Manual for Seminar on Assimilation}

Page 22

People become fully assimilated into the church only over a period of years, and one member can only work with one adoptee at a time. Therefore, though adoption is an excellent way to bring people in, ou will not be able to incorporate people very fast.

\section{[Conclusion, whether family church lecture or Sand dollar effect lecture given above.]}

Small groups allow the church to create as many places as needed in order to bring people into a bonding relationship with the church, and they also provide platforms for outreach.

But whichever method you use to assimilate new members, remember above all, to practice it in the love. Be sure to practice friendship toward all who come through the doors of your congregation, and cause them to feel welcome and a part of all you are doing (individually and corporately).

Discussion - large group 5 min.

Have the group arranged in a circle. Place learning and suggestions on the board. 


\section{Manual for Seminar on Assimilation}

Page 23

\section{Questionnaire. [10 min]}

Please fill out this questionnaire again. There have been some few changes.

When you are finished, I will collect them and we can close with prayer.

\section{Close With Prayer}

[This material was drawn from several sources.] 
APPENDIX D

SUGGESTIONS CONCERNING THE

SPIRITUAL GUARDIAN PROGRAM 
Purpose of the "Barnabas" Ministry: To promote the complete integration of new members into the family of the local church fellowship; physically, spiritually, and socially.

A "Bamabas" is one who is a spiritual guardian and encourager to one who has newly come to the faith. In fact the nave means "Son of Encouragement" and comes from the Biblical person in book of Acts who took the newly converted Saul (Paul) under his wing, and encouraged many other disciples to faithfulness in the church (See Acts 4:34-37; 9:26-28; 11:19-26).

Such spiritual guardians must be chosen because of their stability in the message, and the evidence that the Holy Spirit has given them the gifts needed to nurture friendship and growth in new members, for it is a high calling to be a part of the spiritual development of another of God's children. A "Barnabas" should have a burden for souls and be willing to spend much time in prayer and patient encouragement. Not everybody will be mature in the gifts of faith, mercy, and helps to be of benefit in this way to another. However, God has placed these gifts in the church for this purpose, and by them He indicates those who are to be the Barnabases among us.

We have seen these gifts present in you. And therefore you are being asked to take on the responsibility of guiding, guarding and leading a new member into full church fellowship.

In line with this task, you are being asked by this church to perform the following minimum services to one of our newest members.

1. Contact your spiritual charge at least once every week other than on the Sabbath. This contact can be made by phone or in person. Try, if possible, to make one of these contacts a home visit in their home.

2. Spend as much significant time as possible with them during Sabbath hours at church.

3. Seek opportunities to invite your new friend to group fellowships with you. You will need the help of others to perform your task. These fellowships are wonderful opportunities for your charge to make friends with other members in the faith. (Each new member must make at least six new friends in the church within their first six months of membership if they are to become active in the church fellowship.)

4. Invite them to your home once a month or every two months. Bond with them as best you can so that your friendship will be able to encourage them when other things go wrong in their lives or in the life of the church.

5. Keep track of their spiritual condition, and let the pastor or a trusted elder know if there is a cause for concern. Satan will attack them and try to destroy their new faith, so look out for them as best you can.

6. Help them make friends in the church by introducing them to your circle of friends and acquaintances.

7. Be there for them when they need you to answer questions or just to listen to their needs, fears or complaints. The SDA Church has its own subculture and social signals that can sometimes confuse those new to our ways so try to anticipate their needs and guide them through any sensitive areas.

8. Last, but not least, pray for them and your mission to help them. The spiritual life of one of God's precious children has been placed under your care. Remember that you are flesh. You cannot hope to accomplish this task in your own power or wisdom. Seek God, daily, in prayer that you may be faithful to the task that is before you and that they will be fortified by the Holy Spirit to a mature faith in God through Jesus Christ 
Suggestions for Training

Spiritual Guardians

It would be well to develop a periodic class for those who would like to enter the Barnabas Ministry of Spiritual Guardianship. Here are some suggestions for its content.

1. The Lab I seminar for calling and caring ministries developed by Dr. John Savage (the manuals are referred to in the Bibliography and can be obtained by any Lab II graduate through LEAD

Consultants Inc.). This seminar is excellent in helping church members to become aware of the needs of fellow believers and their cries for help. It also provides training in the use of in-depth listening skills to help them intervene in crises situations. However, it requires in depth training by LEAD consultants to prepare trainers for the local church and the materials are expensive.

2. Modifications of the seminar on assimilation developed for this project. The manual is in appendix $C$. It should be noted that some of the materials in the seminar were lifted from the Lab I manual and should therefore be cleared for use with LEAD

consultants before used in a local church. The exception for this would be if the trainer in the local church has been previously trained by LEAD Consultants in the use of the Lab I materials (i.e., that he or she is a graduate of the Lab II seminar run by LEAD). In this case, he or she already has clearance from LEAD to use these materials in their local church.

3. A one hour class each quarter to help introduce potential spiritual guardians to the document, The Barnabas Ministry, which is also contained in this appendix. The Barnabas Ministry document contains directions acquainting the church members involved with what is expected of them as Spiritual Guardians and how to fulfill those expectations on behalf of the new member they are befriending. 
APPENDIX E

SUPPLEMENTARY ARTICLES AND CHARTS 


\section{HIGH TOUCH IN A DEPERSONALIZED SOCIETY}

Rough Draft for an Article for Ministry magazine (never published) Ralph W. Martin

March 1, 1990

While many leaders in the Adventist church seemed to be looking the other way, John Nesbett scored a bullseye with his

prediction about a "high tech-high touch" society. In his book Megatreands he proposed that in an era of high technology there would be a hunger for high touch from management and community. The more impersonal our tools become, the more we need a friendly, caring environment.

A number of astute pastors have taken this insight seriously and reprogrammed their church for the reality of today, abandoning the assumptions of yesterday. They clearly see that the mission of the church is to grow and their megachurches are based on the axiom that GROWING CHURCHES HAVE HIGH TOUCH. These pastors have become model preachers who made every listener feels personally touched by the sermon; they have established intimate groups which meet weekly for Bible study or self improvement; they encourage congregations to sing emotional choruses that bond them together.

Although Adventist leaders appear late in understanding the full significance of this trend, we are discovering that our members crave this caring touch as much as the general population. We all want to be known and loved. We are hungry to feel our religion as well as hear it. But experience tells us that every pastor cannot grow a megachurch: we are not all gifted communicators; many churches are afraid of the intimacy of small groups; most Adventist churches are leery of emotional displays during the worship service. We sometimes complain about these apparent handicaps, but the chilling forecast is that fewer and fewer church members will stay loyal to an uninvolved, impersonal church.

It is time for Adventists to learn from the megachurches, and get on with the Great Commission. If we are going to hold and add to our membership in the decade of the 1990s, we will have get serious about the "caring church". Administrators must take a personal interest in the goals, desires, and needs of pastors, teachers, and other employees; not view them only as objects of production. Pastors should know the names, understand the problems, and share the joy of members; not see them as pew fillers and automatic cash dispensers. High touch means spending time with a person in a pleasant, productive one-to-one encounter that helps create a united, enthusiastic community of Christians.

How can the average pastor achieve more "high touch"? If you do not have a charismatic, photogenic personality that attracts thousands, you will have to do it the hard way: old fashion home visitation. This is almost a forgotten art for many of us, 
since it went out of style during the cultural revolution of the $70 \mathrm{~s}$ and early $80 \mathrm{~s}$. Now it has becoming necessary again for successful pastoring. If the church is going to counter the deadening secular, materialistic culture surrounding us, we will have to visit members in their homes.

How does a pastor get into a successful visiting program? Here are a few suggestions for those who want to minister more personally to their membership.

1. THE PASTOR SHOULD PLAN THE VISITS A MONTH IN ADVANCE. First decide how much time you can allocate to home visitation each week. An educated guess for a senior pastor is 208 of his working time. This leaves $50 \%$ for preparation and delivery of sermons, and $30 \%$ for administration, crisis ministry, and Bible studies. Since most pastors works 50 or more hours a week, home visitation should receive $8-12$ hours a week.

Write down your visiting schedule and place a family name beside each hour you will visit. Schedule geographically to save time and gas money. By visiting ten home a week, or forty a month, you will make it through your church membership list more quickly than you thought possible.

One hour per home is normally long enough for both the pastor's energy and the family's time. Never underestimate the power of the visit, but do not measure it by time. More than half the value is achieved when you sit down in the living room. A visit from the pastor raises the self image of many members to new heights. They feel personalized. Many will call friends, and/or write to relative to tell them that the pastor called. All this happens just by arriving at the home.

Since most families are only home in the evening, scheduling can be a problem. How can a pastor get 10 hours into an overloaded schedule? Some have found that $4 \mathrm{pm} .-9 \mathrm{pm}$. two days a week is a possibility. An alternative is $4 \mathrm{pm}-9 \mathrm{pm}$ on one day, $1 \mathrm{pm}-3 \mathrm{pm}$ on another, and 7pm- 10pm the third day. This give 10 home visits; it also means missing supper.

2. THE PASTOR SHOULD SEND THE VISITING SCHEDULE BY MAIL TO EVERY CHURCH MEMBER. This may seem strange at first thought, but it is vital to success. Without this strategy the visitation plan usually fails.

It disciplines the pastor to visit. The enemy of visitation is pressure. People are constantly demanding the pastor's time and energy. The first casualty is always home visitation. By mailing the schedule in every member, the congregation knows you have made a contract to visit the families listed, and they will give more respect to your program.

It is comprehensive. Since the pastor will visit every home members do not feel neglected, and inactive members do not feel singled out. Those not attending church will see that the 
pastor is visiting in their area that day, and they are a part of the schedule.

It is time saving. Phoning each home in advance takes time, and frequently results in excuses. When the pastor takes the initiative, most family cooperate. If the family will not be home they are instructed that it is their responsibility to phone the pastor.

It allows the family to prepare for the visit. Most women want their house cleaned and arranged properly when the pastor calls. Advance notice also gives time for the family to think of things they want to talk over with the pastor.

3. THE PASTOR SHOULD UNDERSTAND HIS GOALS FOR THE VISIT, AND HOW TO MOVE THE CONVERSATION TOWARD ACCOMPLISHING THEM. While one important purpose of the call is to bond the pastor with the member or family for the spiritual growth, their are several other vital objectives of the visit as well.

The visit may become a counseling session. The pastor always starts with general conversation, but after about 10 minutes he should change the form of the visit by using the key phrase: "BEFORE I LEAVE, I WANT TO HAVE PRAYER FOR YOU AND YOUR FAMILY. ARE THERE PERSONS OR THINGS YOU WOULD LIKE FOR ME TO PRAY FOR?" The pastor has now moved from a casual visit to a priest ministering the grace and the gospel of Jesus Christ. Almost always the member will open his/her heart to the pastor, telling of either personal or family needs. If the trust level starts low, and no response is given to the first question, the pastor may ask: "Are there things at the church that we ought to be praying for?" Do not delay too long in asking these transition question, or there will not be enough time to properly listen, and have an appropriate closure. This is especially important if the response of the member becomes highly emotional.

The visit will open evangelistic opportunities. The pastor will hear a request in most homes to visit a family member. This is the best form of evangelism. Frequently a mother will ask the pastor to visit a son who is not attending church. At this point the pastor should MAKE A COVENANT with the mother. He agrees to place the son on his visiting schedule next month if the mother will agree to pray for that visit every day until it is made. As soon as the schedule is made for the next month the pastor tells the mother the day and time. Soon as many as half the monthly visits will be evangelistic.

The visit should build a network support system for the member. The COVENANT should begin to tie the mother into a prayer life with other members. For example the pastor may say, "sister Smith, you and I will pray daily for your son, but wouldn't it be good to ask other church members to join us in prayer? Do you have a small group you meet with regularly? The Sabbath School class. Would you be willing to tell them next sabbath about my planned visit with your son, and ask them to pray every day that the visit will go well?" This bonds the mother closer 
to a support group, and the group closer to her. It gives focus to prayer, builds community, and enhances the spiritual life of everyone involved in THE COVENANT.

The pastor can strengthen the support network even more by saying, "Sister Smith, would you like for someone to pray with you every day over the phone about my visit to your son? If so, I will try to find a prayer partner for you?"

The final wrap-up can include this vital question: "If I should find someone else in my visitation who needs prayer for a family member, would you be willing to be a prayer partner?"

The pastor has now set up a valuable support network for the spiritual growth and prayer life of the member.

4. THE PASTOR SHOULD LEAVE AFTER 40-45 MINUTES. When the pastor has read the Bible and prayed he has accomplished almost everything that can be expected from the visit. He can stay longer, but he will miss the next family who may need him desperately. The mailed schedule tells the member that another family is waiting. If there is no satisfactory closure to the visit, the pastor may need to schedule another visit, or to invite the member to meet him at the church office.

Visitation with "high touch" shows Christian love, and builds a caring community. When a pastor has a heart of love, and displays it frequently in pulpit and home, in the sight of God he/she shepherds a megachurch regardless of its size. The Saviors' voice of approval says to that faithful pastor, "Well Done!" 


\section{Membership Size Distribution}

Percent of NAD members

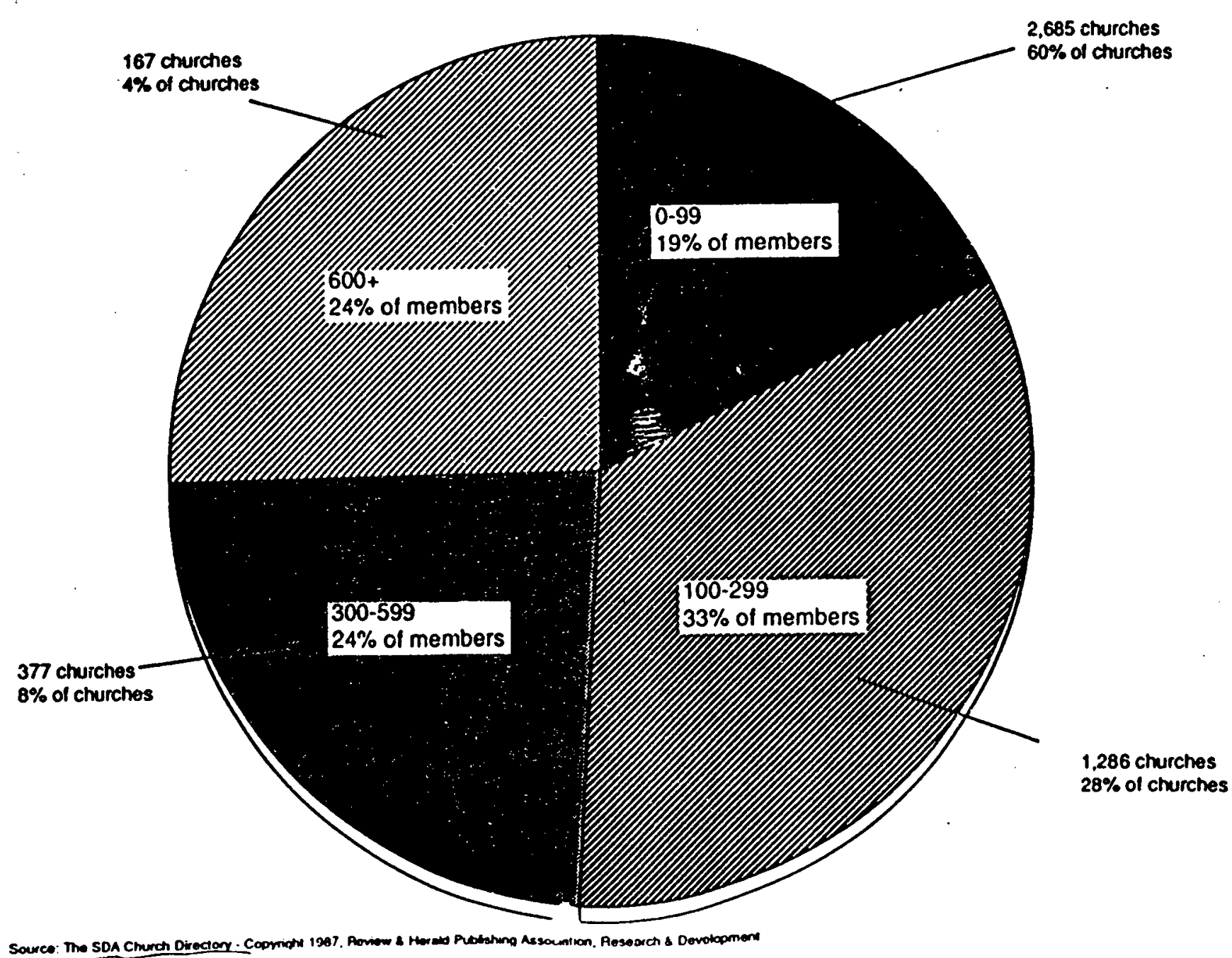


BIBLIOGRAPHY 


\section{BIBLIOGRAPHY}

Annan, Nelson. More People: Is Church Growth Worth It? Wheaton, IL: Harold Shaw Publishers, 1987.

Arn, Win. Growth Report \#1. In Nelson Annan, More People: Is Church Growth Worth It? Wheaton, IL: Harold Shaw Publishers, 1987.

Arn, w. Charles. "Evangelism of Disciple-making?" Church Growth State of the Art. In Roy M. Oswald, and Speed B. Leas, The Inviting Church: A Study of New Member Assimilation. New York: Alban Institute, 1987.

Barna, George. User Friendly Churches. Ventura: Regal Books, 1991.

Bast, Robert L. Attracting New Members. New York and Monrovia: Reformed Church in America and Church Growth, 1988.

Beers, Gilbert. "Big Footprints from Small Churches." Christianity Today, 8 August 1986, 10.

Bird, Warren, and Michelle C. Bird. "When Should Newcomers Become Leaders?" Leadership 11 (Fall 1990): 122-128.

Bondurant, Gary. "Through the Eyes of a Visitor." Ministry, May 1990, 20-21.

Burrill, Russell. "Survey of People at Public Evangelistic Meetings in Spokane, Washington" [photocopy]. NAD Evangelism Institute, La Grange, IL.

Dale, Robert L., Monte Sahlin, Gail R. Hunt, Roger Dudley, Harold Lee, Carole Kilcher, Jose Chavanz-Q. Survey of Lay Leaders: Activities and Programs in 1989, Report 2. Silver Spring, MD: North American Division Church Information System, 1990.

Dudley, Carl S. Unique Dynamics of the Small Church. Washington, DC: Alban Institute, 1977. - Where Have All Our People Gone? New Choices for old Churches. New York: Pilgrim Press, 1979.

Dudley, Roger Lewis, Des Cummings, and Tim Garrison. "A Study of Factors Relating to Church Growth in the Ohio Conference of Seventh-day Adventists." Berrien Springs, MI: Andrews University Institute of Church Ministry, 1983.

Dudley, Roger Lewis, and Des Cummings, Jr. "A Study of Factors Relating to Church Growth in the North American Division of Seventh-day Adventists." Berrien Springs, MI: Andrews University Institute of Church Ministry, April 1981. 
Faith, Action, Advance: Dynamics of Church Growth. Washington, DC: North American Division of the General Conference of Seventh-day Adventists, 1982 .

Finley, Mark. "Friend-to-Friend Evangelism." Update, Summer/Fall 1994, $2,7$.

George, Carl E. Prepare Your Church for the Future. Grand Rapids, MI: Fleming H. Revell, 1992 .

Green, Hollis L. Why Churches Die. Minneapolis, MN: Bethany Fellowship, 1972 .

Heck, Joel D. New Member Assimilation: Practical Prevention of Back Door Loss through Front Door Care. St. Louis: Concordia, 1988.

Holt, Russell B. "The Small Church Advantage." Ministry, March 1987, $18-20$.

Hortop, Kerry H. "The Church as Family: A study of Viability in the Smaller Local Seventh-day Adventist Church." D.Min. project report, Andrews University, Berrien Springs, MI, 1980.

Maner, Robert E. Making the Small Church Grow. Kansas City, MO: Beacon Hill Press, 1982.

Martin, Ralph w. High Touch in a Depersonalized Society. Rough draft of an article for Ministry, March 1, 1990.

Mead, Loren B. More than Numbers: The Way Churches Grow. New York: Alban Institute, 1993.

"Membership Size Distribution: Percent of NAD Members." The SDA Church Directory. Hagerstown, MD: Review \& Herald, Research \& Development, 1987.

Murren, Doug. Skills for Ministry Leaders: Assimilating Newcomers into Ministry. Pasadena, CA: Charles E. Fuller Institute, 1994. Audio cassette in the Pastor's Update Series. Vol. 55.

"New Directions." Adventist Review, 30 December 1993, 14-19.

O'Connor, Father David. "Rural Pastoral Leadership I: The Pastor." In Ministry in the Small Church, ed. David G. Andrews. Kansas City, MO: Sheed and Ward, 1988.

Oertli, Ron. "Finding the Fit." Leadership 11 (Fall 1990): 130-135.

On Line Bible, Version 6.1. Woodside Bible Fellowship, On Line Bible USA, P.O. Box 21, Bronson, MI.

The Open Bible. Expanded ed. Nashville, Camden and New York: Thomas Nelson Publishers, 1980.

Oswald, Roy M. Making Your Church More Inviting. New York: Alban Institute, 1992 .

Oswald, Roy M., and Speed B. Leas. The Inviting Church: A Study of New Member Assimilation. New York: Alban Instutute, 1987. 
Pappas, Anthony G. Entering the World of the Small Church: A Guide for Leaders. New York: Alban Institute, 1992.

Perry, Edward K. Learning About Fishing in Upper New York. A Paper by the president, Upper New York Synod, Lutheran Church of America, April, 1975. Library, Lutheran Theological Seminary, Gettysburg, PA.

Ratz, Calvin C. "The Velcro Church." Leadership 11 (Fall 1990): 38-45.

Ray, David R. Small Churches Are the Right Size. New York: Pilgrim Press, $19 \overline{82 .}$

Rothauge, Arlin J. Sizing Up a Congregation for New Member Ministry. New York: Seabury Professional Services, n.d.

Russel, Gary, ed. "Why Have All the Flowers Gone?" Reclaiming Missing Members I (August 1994): 3.

Savage, John S. "The Teflon Church." Leadership 11 (Fall 1990): 30-37.

Savage, John S., Kenneth J. Mitchell, and Joyce C. Nelson. Lab I Leader's Guide. Pittsford, NY: LEAD Consultants, 1981.

- Lab I Participants Manual, Session I. Pittsford, NY: LEAD Consultants, 1981 .

Schaller, Lyle E. Assimilating New Members. Nashville: Abingdon, 1978.

- Growing Plans. Nashville: Abingdon, 1983.

- The Small Church Is Different. Nashville: Abingdon, 1982.

- "Twenty Questions for Self Evaluation in the Small and

Middle Sized Church." Church Management 8 (April 1977): 15-17, 22 .

Schreven, Leo. "New Members and the Disappearing Act." Adventist Review, 7 October 1993, 12-14.

Sells, L. Ray, and Ronald K. Crandall. The Small Membership Church Growing, Caring, Serving: A Manual for Evangelism Ministries. Nashville: Discipleship Resources, 1982 .

Shellbey, Marshall. "From the Editor." Leadership 11 (Fall 1990): 3.

Sherif, Muzafer, and Carl I. Hovland. Social Judgment, Assimilation and Contrast Effects in Communication and Attitude Change. Westport, CT: Greenwood Press, 1961.

Stafford, Thomas A. "Tacoma Central Seventh-day Adventist Church: The Interdependent Ministry of the Pastor and Head Elder." D.Min. Project Dissertation, Fuller Theological Seminary, January 1985.

Strahan, Brad. "Adventist Attitudes: A Research Repoort." South Pacific Record and Adventist World Survey, 13 January 1990, 6. 
Voyles, Ernie. Quoted in Monte Sahlin in addition to Fordyce $w$. Detamore, Seeking His Lost Sheep. Hagerstown, MD: Review and Herald, 1989.

White, Ellen G. "Notes of Travel--No. 5, Los Angeles, Cal." Advent Review and Sabbath Herald, 2 March 1905, 8,9.

- "Our Youth and Children Demand Our Care." Advent Review and Sabbath Herald, 28 April 1896, 257-258.

- "Serving God Fervently." Advent Review and Sabbath Herald, 26 July $1887,465$.

- Testimonies to the Church. 9 vols. Mountain View, CA: Pacific Press, 1900.

Wicker, Allen w. "Assimilation of New Members and a Small Church." Journal of Applied Psychology 55 (1971): 151-156.

Wiggins, Kimbleton S. Soul Winning Made Easy. Mountain View, CA: Pacific Press, 1975.

Yost, F. Donald. "Seven Adventist Trends: Statistical Profile of a Changing Church." Dialogue 2, 1990, 8-10. 
VITA 
VITA

Robert C. Williams is a pastor in central Pennsylvania, serving the Gettysburg and York Springs Seventh-day Adventist Churches. He grew up. in Grand Rapids, MI, and graduated from Creston High School in 1964. He then attended the Grand Rapids Junior College for two years before completing his undergraduate education at Central Michigan University, in Mt. Pleasant, MI. He graduated there with a Bachelor of Science Degree and a high school teaching certification in 1968.

He taught 9 th through 11th grade English at Central High School in Grand Rapids until 1971 when he moved to Berkeley, CA. It was during this time that he learned of the Three Angel's Messages and he was baptized into fellowship at the Berkeley Seventh-day Adventist Church following "Mission 72." He served the Lord for a time as administrator of the Vege Hut Restaurant, a self supporting outreach in the Haight-Ashbury section of San Francisco. Then he married and moved with his wife to Chattanooga, TN, where he worked as a reading therapist. In 1976, in response to the calling of the Lord, he attended Andrews University Theological Seminary to prepare for the ministry, and graduated with a Master of Divinity degree in 1979. Since that time he has served in three small-church districts in Pennsylvania.

In addition to these things he presently serves as a member of the Blue Mountain Accademy Board and the $\mathrm{K}-12$ Board for the Pennsylvania Conference of Seventh-day Adventists. He has held positions on the Pennsylvania Conference Committee for past administrations.

Pastor Williams is the husband of one wife, and the father of three beautiful young women. Two are in attendance at Blue Mountain Academy, and one is presently attending Southern College in Tennessee. He sees them occasionally when he comes up for air after periods of working on this research paper. 